AUTARQUIA ASSOCIADA À UNIVERSIDADE DE SÃO PAULO

\title{
INFLUÊNCIA DOS PARÂMETROS DE PROCESSAMENTO NA MICROESTRUTURA E NAS PROPRIEDADES MAGNÉTICAS DE ÍMÃS PERMANENTES DE (Nd,Pr)FeB
}

RAFAEL GITTI TORTORETTO FIM

Dissertação apresentada como parte dos requisitos para obtenção do Grau de Mestre em Ciências na Área de Tecnologia Nuclear - Materiais

Orientador:

Prof. Dr. Hidetoshi Takiishi 
INSTITUTO DE PESQUISAS ENERGÉTICAS E NUCLEARES

Autarquia associada à Universidade de São Paulo

INFLUÊNCIA DOS PARÂMETROS DE PROCESSAMENTO NA MICROESTRUTURA E NAS PROPRIEDADES MAGNÉTICAS DE ÍMÃS PERMANENTES DE (Nd,Pr)FeB

RAFAEL GITTI TORTORETTO FIM

Dissertação apresentada como parte dos requisitos para obtenção do Grau de Mestre em Ciências na Área de Tecnologia Nuclear - Materiais

Orientador:

Prof. Dr. Hidetoshi Takiishi 
À minha família e à minha querida Melissa, com muito carinho e gratidão. 


\section{AGRADECIMENTOS}

Gostaria de agradecer com muita gratidão todos aqueles que tornaram possível a realização do presente trabalho:

Ao Dr. Hidetoshi Takiishi, pela orientação, oportunidade e amizade desenvolvida desde a minha iniciação científica;

Ao Dr. Rubens Nunes de Faria Jr., pelo apoio e contribuições com o trabalho durante este período;

Aos membros da banca examinadora, Dr. Paulo Wendhausen e Dr. Daniel Rodrigues, por aceitarem participar e assim contribuir com o presente trabalho;

Ao Dr. Ricardo Mendes Leal, por disponibilizar o Moinho Planetário de Alta Energia para o desenvolvimento do presente trabalho;

A Dra. Luzinete Barbosa e a Dra. Suelanny Carvalho, por todo o auxílio prestado e amizade desenvolvida durante esses anos presentes no IPEN;

Ao Msc. Edson Pereira Soares, por todo o auxílio desde o período de iniciação científica e pela amizade desenvolvida durante esses anos.

A CAPES pelo auxílio financeiro durante a realização deste trabalho;

Ao Instituto de Pesquisas Energéticas Nucleares (IPEN/CNEN-SP) pela oportunidade concedida no desenvolvimento deste projeto;

Aos meus mestres professores de graduação, especialmente a Dr. Lilian Hanamoto, Dr. Marcos Xavier, Dr. Djanilson Vanderlei (in memoriam), Dr. Davinson Mariano e Dr. Katsuyoshi Kurata, que contribuíram com excelência para minha formação profissional e pessoal.

Aos meus companheiros mestrandos e doutorandos, que me acompanharam nessa jornada, dividindo muitos momentos bons: Juliana Pereira de Souza, Tatiana Martinez, Ana Paula Curcio, Mariana Lima, Aline Bugarin, Gleicy Lima, Fernando Gabriel Benitez, Felippe Bartalo, Jefferson Matsui e Rafael Denaldi;

À minha família, que me deu todo o suporte e apoio necessários para que pudesse concluir esta dissertação;

À minha querida Melissa Röhrig, que além de todo o auxílio com o presente trabalho, foi a minha base sólida sob a qual eu me apoiei e grande companheira que esteve presente em todo este ciclo. 
"A verdadeira viagem de descobrimento não consiste em procurar novas paisagens, mas em ter novos olhos."

(Marcel Proust) 
"Que vossos esforços desafiem as impossibilidades, lembraivos de que as grandes coisas do homem foram conquistadas do que parecia impossível."

(Charles Chaplin) 


\title{
INFLUÊNCIA DOS PARÂMETROS DE PROCESSAMENTO NA MICROESTRUTURA E NAS PROPRIEDADES MAGNÉTICAS DE ÍMÃS PERMANENTES DE (Nd,Pr)FeB
}

\author{
RAFAEL GITTI TORTORETTO FIM
}

\section{RESUMO}

Os ímãs permanentes de terras-raras desempenham um papel vital na indústria de dispositivos eletromagnéticos. As principais aplicações destes materiais na indústria são na produção de motores para veículos elétricos e híbridos e geradores para turbinas eólicas. Com a restrição chinesa a exportação de terras-raras em 2010, os elevados preços e a necessidade de substituição dos terras-raras pesados (Dy e Tb) nos ímãs permanentes, há um interesse mundial por alternativas. No processamento de ímãs permanentes de terras-raras, a moagem é uma etapa determinante, controlando e homogeneizando a microestrutura final do ímã, aumentando as propriedades magnéticas. O presente trabalho avalia a influência de diferentes tempos de moagem na microestrutura e nas propriedades magnéticas de ímãs permanentes sinterizados. Os ímãs foram preparados via metalurgia do pó, a partir de pós obtidos pelo processo de decrepitação por hidrogênio (HD) feito na liga Strip-Casting de composição $(\mathrm{Nd}, \mathrm{Pr})_{13,49} \mathrm{Fe}_{77,72} \mathrm{~B}_{6} \mathrm{Co}_{1,1} \mathrm{Al}_{1,2} \mathrm{Nb}_{0,28} \mathrm{Cu}_{0,2}$. A moagem dos pós foi realizada em meio de ciclohexano em Moinho Planetário de Alta Energia, durante um período entre 30 e 75 minutos, com intervalos regulares de 15 minutos, a uma velocidade fixa de 200 rpm. Os ímãs produzidos foram caracterizados por Microscopia Eletrônica de Varredura (MEV), Espectroscopia de Energia Dispersiva (EDS), Difração de Raios-X (DRX), as propriedades magnéticas foram obtidas por meio de Permeâmetro e a textura cristalográfica dos ímãs foi calculada a partir dos difratogramas obtidos. O ímã produzido com 45 minutos de moagem (45-B) apresentou remanência $B_{r}=1,38 \mathrm{~T}$, coercividade intrínseca ${ }_{i} \mathrm{H}_{\mathrm{c}}=880 \mathrm{KA} \cdot \mathrm{m}^{-1}$, produto de energia máximo $\mathrm{BH}_{\text {máx }}=330 \mathrm{KJ} \cdot \mathrm{m}^{-1}$, fator de quadratura $\mathrm{SF}=0,95 \mathrm{e}$ grau de alinhamento $\langle\cos \theta>=0,96$. 


\title{
INFLUENCE OF PROCESSING PARAMETERS ON THE MICROSTRUCTURE AND MAGNETIC PROPERTIES OF (Nd,Pr)FeB PERMANENT MAGNETS
}

\author{
RAFAEL GITTI TORTORETTO FIM
}

\begin{abstract}
Rare-earth permanent magnets plays a vital role on the electromagnetic devices industry. The major applications of this material industrially are in the production of motors for electric and hybrid vehicles and magnetic generators for wind turbines. With the Chinese restriction of rare-earth exportations in 2010, the high prices and the need to substitute the heavy rare-earths (Dy,Tb) in the permanent magnets, there is a global interest in alternatives. In the processing of rare earth permanent magnets, the milling process is a determinant step, controlling and homogenizing the microstructure of the magnet, increasing its properties. The present work evaluates the influence of different high energy planetary ball milling times on the microstructure and the magnetic properties of sintered permanent magnets. The magnets were prepared via conventional powder metallurgy route, using powders obtained by the hydrogen decrepitation process (HD) made in the (Nd, $\operatorname{Pr})_{13.49} \mathrm{Fe}_{77.72} \mathrm{~B}_{6} \mathrm{Co}_{1,1} \mathrm{Al}_{1,2} \mathrm{Nb}_{0,28} \mathrm{Cu}_{0,2}$. Strip-Casting alloy. The milling process was carried under ciclohexane medium, using a High Energy Planetary Mill for a period between 30 and 75 minutes, with regular intervals of 15 minutes at a speed of 200 rpm. The magnets were characterized by Scanning Electron Microscopy (SEM), Dispersive Energy Spectroscopy (EDS), X-ray Diffraction (XRD), and magnetic properties were obtained by Permeameter. The magnet produced with 45 minutes of milling (45-B) presented $B_{r}=1.38 \mathrm{~T}$, intrinsic coercivity ${ }_{i} \mathrm{H}_{\mathrm{c}}=880 \mathrm{KA} \cdot \mathrm{m}^{-1}$, maximum energy product $\mathrm{BH}_{\mathrm{MÁx}}=330 \mathrm{KJ} \cdot \mathrm{m}^{-1}$, squareness factor $\mathrm{SF}=0,95$ and alignment degree $<\cos \theta>=0,96$.
\end{abstract}




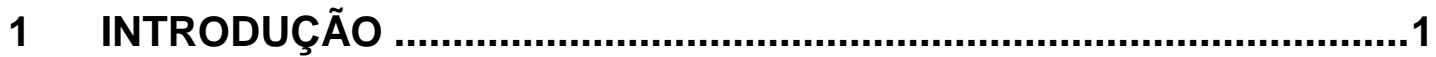 \\ Sumário}

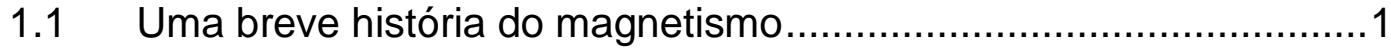

1.2 Um breve histórico dos ímãs permanentes ...............................4

1.3 Terras-Raras: contexto atual e aplicações nos ímãs permanentes..6

1.3.1 Aplicações dos ímãs permanentes de NdFeB ...........................8

1.3.2 O uso de terras-raras pesados na produção dos ímãs permanentes

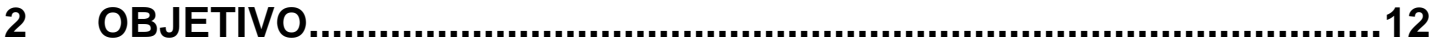

3 REVISÃO DE LITERATURA ........................................................12

3.1 Propriedades magnéticas dos materiais ..................................12

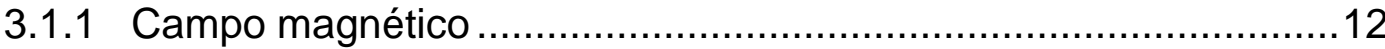

3.1.2 Momento magnético.......................................................12

3.1.3 Dipolo magnético ..........................................................

3.1.4 Magnetização e Indução Magnética..........................................13

3.1.5 Permeabilidade e Susceptibilidade Magnética...........................14

3.1.6 Classificação dos Materiais ................................................. 15

3.1.7 Os Domínios Magnéticos e as Paredes de Bloch ........................16

3.1.8 Anisotropia Magnetocristalina ........................................... 18

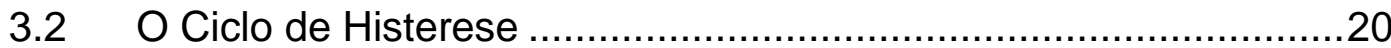

3.3 O processo de Decrepitação por Hidrogênio (HD) .........................25

3.4 A Moagem de Alta Energia (MAE) nos ímãs permanentes de

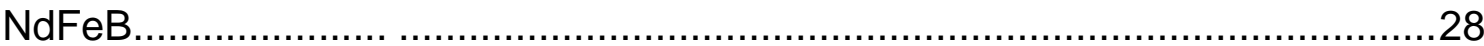

4 MATERIAIS E MÉTODOS...................................................................30

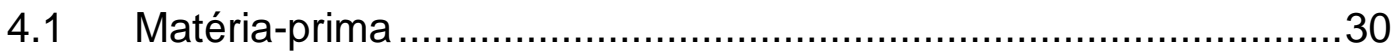

4.2 Processo de Produção dos Ímãs ........................................... 31

4.2.1 Decrepitação por Hidrogênio (HD) .......................................31

4.2.2 Moagem Planetária de Alta Energia..........................................32 
4.2.3 Secagem e Transferência .................................................33

4.2.4 Alinhamento de Partículas e Compactação .................................34

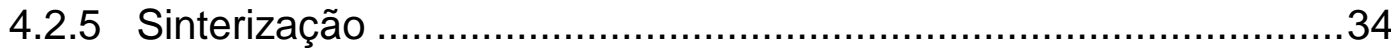

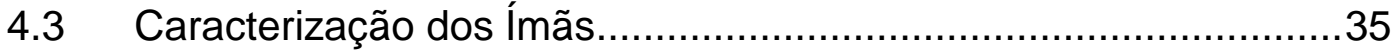

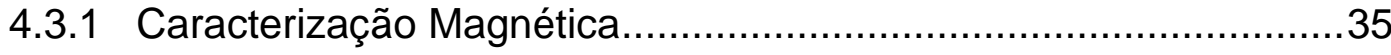

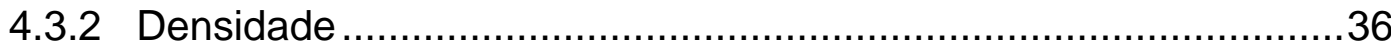

4.3.3 Caracterização Metalográfica........................................... 36

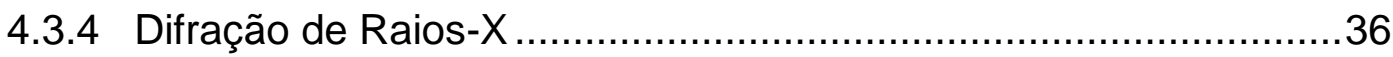

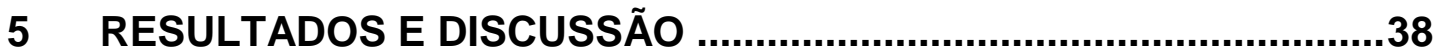

5.1 Caracterização Magnética................................................. 38

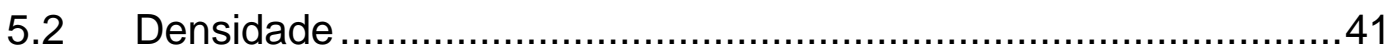

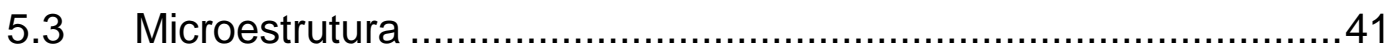

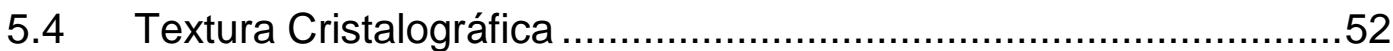

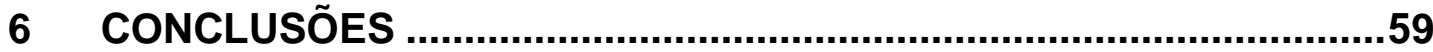

7 REFERÊNCIAS BIBLIOGRÁFICAS ...............................................62 


\section{LISTA DE TABELAS}

Tabela 1: Utilização dos terras-raras por aplicação, dados em porcentagem (\%). Adaptado de [9]

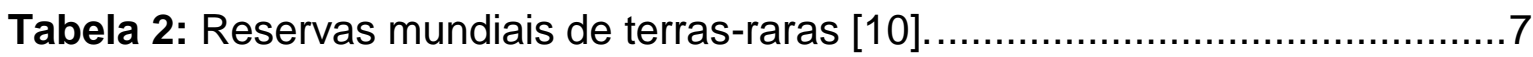

Tabela 3: Composição química da liga strip-cast. .................................... 30

Tabela 4: Propriedades magnéticas dos ímãs produzidos. ..............................38

Tabela 5: Densidade hidrostática dos ímãs sinterizados produzidos. ................41

Tabela 6: Diâmetro médio dos grãos e seus respectivos desvios.....................51

Tabela 7: Cálculo do grau de alinhamento dos ímãs produzidos. ......................55

Tabela 8: Valores de remanência $\left(B_{r}\right)$ calculados em função do grau de

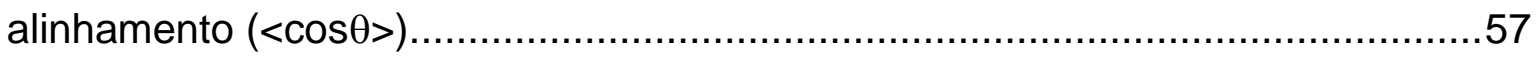

Tabela 9: Valores da fração volumétrica de fase magnética calculada a partir das propriedades magnéticas dos ímãs produzidos. .58 


\section{LISTA DE FIGURAS}

Figura 1: Evolução dos ímãs.

Figura 2: Distribuição das reservas de terras-raras no Brasil.

Figura 3: Gerador magnético de uma turbina eólica.

Figura 4: Îmãs permanentes em um motor de um veículo elétrico (Toyota Prius).

Figura 5: Movimentação dos domínios magnéticos e das paredes de Bloch......17

Figura 6: Processo de saturação magnética de um material ferromagnético. .....18

Figura 7: Ciclo de histerese de um material ferromagnético. .........................21

Figura 8: Curva de desmagnetização de um ímã permanente .........................23

Figura 9: Processo de dcrepitação por hidrogênio (HD) .............................26

Figura 10: Sítios intersticiais ocupados pelo $\mathrm{H}_{2}$ na estrutura do composto $\mathrm{Nd}_{2} \mathrm{Fe}_{14} \mathrm{~B}$ 28

Figura 11: Curvas de desmagnetização dos ímãs sinterizados produzidos. 38

Figura 12: Microscopia eletrônica de varredura (elétrons retroespalhados) do ímã produzido com 30 minutos de moagem.

Figura 13: Microscopia eletrônica de varredura (elétrons retroespalhados) do ímã produzido com 45 minutos (45-A) de moagem.

Figura 14: Microscopia eletrônica de varredura (elétrons retroespalhados) do ímã produzido com 45 minutos (45-B) de moagem. .43

Figura 15: Microscopia eletrônica de varredura (elétrons retroespalhados) do ímã produzido com 60 minutos de moagem. .43

Figura 16: Microscopia eletrônica de varredura (elétrons retroespalhados) do ímã produzido com 75 minutos de moagem. .44 
Figura 17: Microscopia eletrônica de varredura (elétrons retroespalhados) do ímã produzido com 30 minutos de moagem. Ataque superficial: solução $0,2 \mathrm{~mol}$ de $\mathrm{HNO}_{3}$. .45

Figura 18: Microscopia eletrônica de varredura (elétrons retroespalhados) do ímã produzido com 45 minutos de moagem (45-A). Ataque superficial: solução $0,2 \mathrm{~mol}$ de $\mathrm{HNO}_{3}$. .45

Figura 19: Microscopia eletrônica de varredura (elétrons retroespalhados) do ímã produzido com 45 minutos de moagem (45-B). Ataque superficial: solução $0,2 \mathrm{~mol}$ de $\mathrm{HNO}_{3}$ 46

Figura 20: Microscopia eletrônica de varredura (elétrons retroespalhados) do ímã produzido com 60 minutos de moagem. Ataque superficial: solução $0,2 \mathrm{~mol}$ de $\mathrm{HNO}_{3}$ .46

Figura 21: Microscopia eletrônica de varredura (elétrons retroespalhados) do ímã produzido com 75 minutos de moagem. Ataque superficial: solução $0,2 \mathrm{~mol}$ de $\mathrm{HNO}_{3}$

Figura 22: Distribuição dos tamanhos de grãos do ímã produzido com 30 minutos de moagem.

Figura 23: Distribuição dos tamanhos de grãos do ímã produzido com 45 minutos de moagem (45-A). .49

Figura 24: Distribuição dos tamanhos de grãos do ímã produzido com 45 minutos de moagem (45-B). 49

Figura 25: Distribuição dos tamanhos de grãos do ímã produzido com 60 minutos de moagem. .50

Figura 26: Distribuição dos tamanhos de grãos do ímã produzido com 75 minutos de moagem. .50 
Figura 27: Padrão de difração de raios-X do ímã produzido com 30 minutos de moagem. .53

Figura 28: Padrão de difração de raios-X do ímã produzido com 45 minutos de moagem (45-A). .53

Figura 29: Padrão de difração de raios-X do ímã produzido com 45 minutos de moagem (45-B). 54

Figura 30: Padrão de difração de raios-X do ímã produzido com 60 minutos de moagem. .54

Figura 31: Padrão de difração de raios-X do ímã produzido com 75 minutos de moagem. 55 


\section{LISTA DE ABREVIATURAS}

$\mathrm{FQ}$

$\mathrm{HD}$

MAE

MEV

TR

TR-Fe-B

$\mathrm{TR}_{2} \mathrm{Fe}_{14} \mathrm{~B}$
Fator de Quadratura;

Decrepitação por Hidrogênio (Hydrogen Decrepitation);

Moagem de Alta Energia;

Microscopia Eletrônica de Varredura;

Terras-Raras;

Ímãs ou ligas compostos majoritariamente por um elemento terra-rara, ferro e boro;

Fase magnética (matriz) em ímãs de terras-raras. 


\section{LISTA DE SÍMBOLOS}
A
Ampère;
Área.
B
Indução magnética ou densidade de fluxo.
$(\mathrm{BH})_{\mathrm{MÁX}}$
Produto de Energia Máximo.
$\mathrm{B}_{\mathrm{r}}$ Remanência.
Fração volumétrica de fase magnética em um ímã permanente.
$\mathrm{H} \quad$ Intensidade de campo magnético aplicado.
- $\mathrm{H} \quad$ Intensidade de campo magnético reverso.
$\mathrm{H}_{\mathrm{A}} \quad$ Campo de anisotropia magnetocristalina.
${ }_{b} \mathrm{H}_{\mathrm{C}} \quad$ Coercividade indutiva.
${ }_{\mathrm{i}} \mathrm{H}_{\mathrm{c}} \quad$ Coercividade intrínseca.
$\mathrm{H}_{\mathrm{k}} \quad$ Campo reverso aplicado para reduzir a remanência em 10\%.
lobs Intensidade das reflexões (hkl) observadas nas amostras anisotrópicas.
I// Intensidade relativa das reflexões (hkl) de um ímã isotrópico.
J Intensidade de corrente;
Polarização magnética.
$\mathrm{J}_{\mathrm{s}} \quad$ Polarização de saturação.
K Kelvin.
$\mathrm{K}_{1}, \mathrm{~K}_{2}, \mathrm{~K}_{3} \ldots \quad$ Constantes anisotrópicas.
M Magnetização.
$\mathrm{M}_{\mathrm{s}} \quad$ Magnetização de saturação.
m Metro;
Momento magnético.
$\mathrm{m}_{\mathrm{i}} \quad$ Massa imersa do ímã em água deionizada para determinação da densidade.
$\mathrm{m}_{\mathrm{s}} \quad$ Massa seca do ímã para determinação da densidade.
$\mathrm{m}_{\mathrm{u}} \quad$ Massa úmida do ímã para determinação da densidade.
P Fator de empacotamento;
Densidade relativa. 
$\mathrm{T}$

$\mathrm{T}_{\mathrm{C}}$

$\mathrm{V}$

$<\cos \theta>$

$\Phi$

$\alpha$

$\lambda$

$\mu$

$\mu 0$

$\rho$

$\varphi$

$\chi$
Tesla.

Temperatura de Curie.

Volume.

Grau de alinhamento (textura) cristalográfico.

Identificação da fase matriz $\left(\mathrm{Nd}_{2} \mathrm{Fe}_{14} \mathrm{~B}\right)$.

Ângulo entre o eixo c da estrutura tetragonal da fase Nd2Fe14B e a direção do campo magnético aplicado para orientação das partículas.

Ângulo de rotação da amostra em relação a um eixo normal a sua superfície.

Comprimento de onda.

Identificação da fase rica em $\mathrm{Nd}$ (Nd3FeCo);

Permeabilidade Magnética.

Permeabilidade Magnética no vácuo.

Densidade.

Ângulo entre um plano (hkl) e o plano (00l).

Susceptibilidade Magnética. 


\section{INTRODUÇÃO}

\subsection{Uma breve história do magnetismo}

A história do magnetismo e dos materiais magnéticos começou há mais de 2500 anos, com um material que apresentava características magnéticas, denominado magnetita $\left(\mathrm{Fe}_{3} \mathrm{O}_{4}\right)$. Este material foi o primeiro contato que o homem teve com o magnetismo $[1,2]$.

$\mathrm{Na}$ antiguidade, este material era encontrado em uma região chamada Magnésia (o que corresponde atualmente ao território da Turquia) e por isso foi batizado de magnetita. Nessa mesma época, também era conhecido pelos gregos, que um pedaço de ferro que tivesse sido atritado pela magnetita, se tornaria magnético [1,2].

Civilizações localizadas na Suméria, Grécia, China e na América précolombiana já estava familiarizadas com os ímãs naturais. Os chineses desenvolveram um dispositivo magnético, que era composto por uma peça de lodestone em formato de colher, que apontava para o sul [2].

Tales de Mileto, Platão e Aristóteles já sabiam da existência dos ímãs naturais e de sua atração pelo ferro. Muitos outros filósofos e pensadores antigos descreviam tais fenômenos, porém quase nada se sabia sobre o magnetismo, até o período medieval [2].

Messahalla (ou Masha'allah, 762-815), um importante astrólogo persa postulou em um de seus estudos, uma interessante abordagem a respeito do magnetismo, associando-o à influência astrológica. Messahalla escreveu que "a ação dos planetas sobre este mundo é semelhante a do magneto sobre o ferro; pois assim como o ferro é atraído por essa pedra até uma distância conhecida, da mesma forma toda criatura e todas as coisas que estão sobre a Terra são produzidas pelo movimento dos planetas [...]" [3].

Na sua obra De quindecim stellis, quindecim lapidibus, quindecim herbis et quindecim imaginibus, Messahalla estabelece uma conexão entre a magnetita e o brilho de uma das estrelas da Ursa Maior (no texto chamada de Benenays), indicando que os pensadores árabes já sabiam que os ímãs giravam e apontavam para o norte [3]. 
Os estudos mais antigos referentes à bussola surgiram na Europa entre o final do século XII e o início do século XIII. Os três estudos considerados os mais antigos sobre a bússola são de Alexandre Neckam (1157-1217), Guyot de Provins (1184-1210) e Jacques de Vitry (1165-1240) [3,4].

No século XIII, um passo muito importante no desenvolvimento do magnetismo foi dado. Pierre de Maricourt (ou Petrus Peregrinus), um dos mais importantes pesquisadores medievais, publicou em 1269 a sua obra intitulada Epistola Petri Peregrini De Magnete, com estudos experimentais que esclareceram muitos aspectos ainda não estudados - como a descoberta dos polos magnéticos, explicações sobre a atração entre polos opostos e repulsão entre polos do mesmo tipo, e até o termo "polo" parece ser original desta obra [3].

Após um hiato de quase 400 anos, William Gilbert publicou seu trabalho em 1600 intitulado De Magnete, considerado por muitos o primeiro trabalho científico sobre o magnetismo. Em sua obra, Gilbert desmistificou muitos conceitos relacionados ao magnetismo [5].

Através de suas experiências com uma esfera de lodestone (ou terella), Gilbert foi capaz de identificar e mapear a origem da força magnética que alinhava a agulha de uma bússola com a Terra em si, e inferiu que a Terra também era um enorme ímã, explicando o motivo pelo qual a bússola se orienta na direção nortesul [5].

Por quase dois séculos, o trabalho de Gilbert permaneceu como única contribuição científica relevante sobre o magnetismo. A maior contribuição técnica sobre o magnetismo na época ocorreu em 1743 por Daniel Bernouilli, que descobriu que o formato ideal para um ímã seria o formato de "ferradura", resolvendo o problema da desmagnetização em barras de ferro. Porém somente em 1755 esta solução foi realmente empregada por Johann Dietrich [5].

Em 1790, Alessandro Volta descobriu a pilha, possibilitando a geração de corrente elétrica. Impulsionado pela descoberta de Volta, Hans Oersted em 1820, descobriu que uma corrente elétrica passando por um fio de cobre gera um campo magnético ao redor deste fio. A descoberta de Oersted impulsionou os estudos no campo do eletromagnetismo, permitindo a produção do primeiro eletroímã em 1825, por William Sturgeon [5]. 
A ciência experimental do século XIX foi revolucionada por Michael Faraday e seus estudos. Trabalhando quase totalmente de forma experimental, Faraday desenvolveu o conceito de "campo magnético". Também desenvolveu a classificação dos materiais conforme o comportamento magnético que apresentavam, introduzindo os conceitos de paramagnetismo e diamagnetismo [5].

Trabalhando com um eletroímã, Faraday descobriu o fenômeno da "indução magnética", postulando que cargas elétricas podem ser induzidas por uma variação no campo magnético [5].

Quase que de forma simultânea, uma teoria clássica que relacionava o magnetismo e a eletricidade surgiu em 1824, desenvolvida por Poisson. Wilhelm Weber apresentou formalmente a ideia de que os átomos de ferro eram capazes de se alinhar conforme a presença de um campo magnético, dando início às explicações sobre a histerese [5].

Em 1873, James Clerk Maxwell em seu trabalho Treatise on Electricity and Magnetism formalmente definiu a relação entre eletricidade e magnetismo - que uma carga elétrica oscilando produz um campo eletromagnético. Em seu trabalho, Maxwell considerava uma onda eletromagnética se propagando à velocidade da luz. Em 1888, Heinrich Hertz mostrou que as ondas eletromagnéticas descritas por Maxwell eram idênticas as ondas de luz, de rádio e etc [5].

Em 1895, Pierre Curie descobre o ponto de Curie (ou temperatura de Curie), sendo a temperatura crítica onde acima desta os materiais perdem suas características ferromagnéticas [5]

A descoberta do elétron no final do século XIX permitiu um gigantesco avanço em direção à compreensão fundamental do magnetismo. Em 1900, George Francis Fitzgerald sugere que o magnetismo é uma consequência da rotação dos elétrons nos átomos [5].

Quando a física clássica já não era mais capaz de explicar os fenômenos magnéticos, a mecânica quântica surge e amplia os horizontes nos estudos sobre o magnetismo. Uma nova compreensão sobre o magnetismo foi criada a partir da física quântica formulada por Einstein, Bohr, Pauli, Dirac, Schrödinger e Heisenberg. A partir daí, foi possível identificar a fonte do magnetismo nos 
materiais como sendo o momento angular de partículas elementares como o elétron [5].

Em 1932, Louis Neél e sua extensão da teoria de Pierre Weiss difunde o conceito de antiferromagnetismo. Weiss, que introduziu o conceito de domínios magnéticos, teve sua teoria confirmada após Bitter visualizar tais regiões, em 1931. Ainda em 1932, Bloch introduziu a ideia de paredes de domínios [5].

\subsection{Um breve histórico dos ímãs permanentes}

A partir dos anos 1920, o desenvolvimento de materiais magnéticos começou a evoluir mais rapidamente. No começo do século $X X$, os ímãs utilizados eram compostos de aço endurecido por carbono. Esses ímãs perdiam grande parte de sua energia devido à defeitos microestruturais e discordâncias, apresentando propriedades magnéticas muito reduzidas $\left((\mathrm{BH})_{\operatorname{máx}} \approx 8 \mathrm{KJ} / \mathrm{m}^{3}\right)[6]$.

Em 1932, a primeira série de ligas compostas por alumínio, níquel e cobalto foi descoberta por Mishima. Essa composição ternária foi batizada de Alnico referente aos componentes da liga. Os Alnicos 1-4 foram a primeira série de materiais dessa classe, onde o teor de cobalto variava de 3 a 20\%. Por serem isotrópicos, apresentavam propriedades magnéticas reduzidas $\left((\mathrm{BH})_{\mathrm{MÁX}}=10-16\right.$ $\left.\mathrm{KJ} / \mathrm{m}^{3}\right)$. Nos anos seguintes, outras séries dos Alnicos surgiram e suas propriedades magnéticas eram cada vez maiores. Os Alnico 8 possuiam teores de titânio variando entre 4 e $8 \%\left((\mathrm{BH})_{\text {MÁx }}=40-48 \mathrm{KJ} / \mathrm{m}^{3}\right)$ e os Alnico 9 colunares continham ainda $0,3 \%$ de enxofre $\left((\mathrm{BH})_{\text {MÁx }}=60-75 \mathrm{KJ} / \mathrm{m}^{3}\right)[6]$.

Já na década de 50, a Phillips desenvolveu ímãs cerâmicos feitos de óxidos de ferro, de bário e de estrôncio, que foram denominados ferrites ou ferritas. Os ferrites tornaram-se os ímãs mais utilizados comercialmente devido ao baixo custo de produção $[6,7]$.

No final dos anos 60, foi desenvolvido por pesquisadores americanos da Phillips, o primeiro ímã permanente utilizando-se de ligas de terras-raras com metal de transição $\left(\mathrm{SmCO}_{5}\right)$. Suas propriedades magnéticas são atribuídas a alta anisotropia magnetocristalina, sendo o eixo de fácil magnetização paralelo ao eixo $c$ da estrutura hexagonal. Estes ímãs apresentavam propriedades magnéticas muito superiores aos antecessores $\left((\mathrm{BH})_{\mathrm{MÁX}}=180 \mathrm{KJ} / \mathrm{m}^{3}\right)$. Com a crise do cobalto 
nos anos 70, a produção em larga escala dos ímãs de $\mathrm{SmCo}_{5}$ tornou-se inviável e a pesquisa por alternativas ao samário e cobalto foram se intensificando [6].

Em 1983 chegou-se a composição ternária NdFeB. Este novo material apresentou propriedades muito superiores e menor custo de fabricação em relação aos seus antecessores à base de Sm-Co [4]. Devido a sua alta anisotropia magnetocristalina da fase tetragonal $\mathrm{Nd}_{2} \mathrm{Fe}_{14} \mathrm{~B}$, foi possível obter propriedades magnéticas elevadas jamais alcançadas até então $\left((\mathrm{BH})_{\text {MÁX }}>400\right.$ $\left.\mathrm{KJ} / \mathrm{m}^{3}\right)$. A Fig.1 apresenta a evolução do produto de energia máximo $\left((\mathrm{BH})_{\mathrm{MÁX}}\right)$ dos ímãs com o tempo [6].

Figura 1: Evolução dos ímãs.

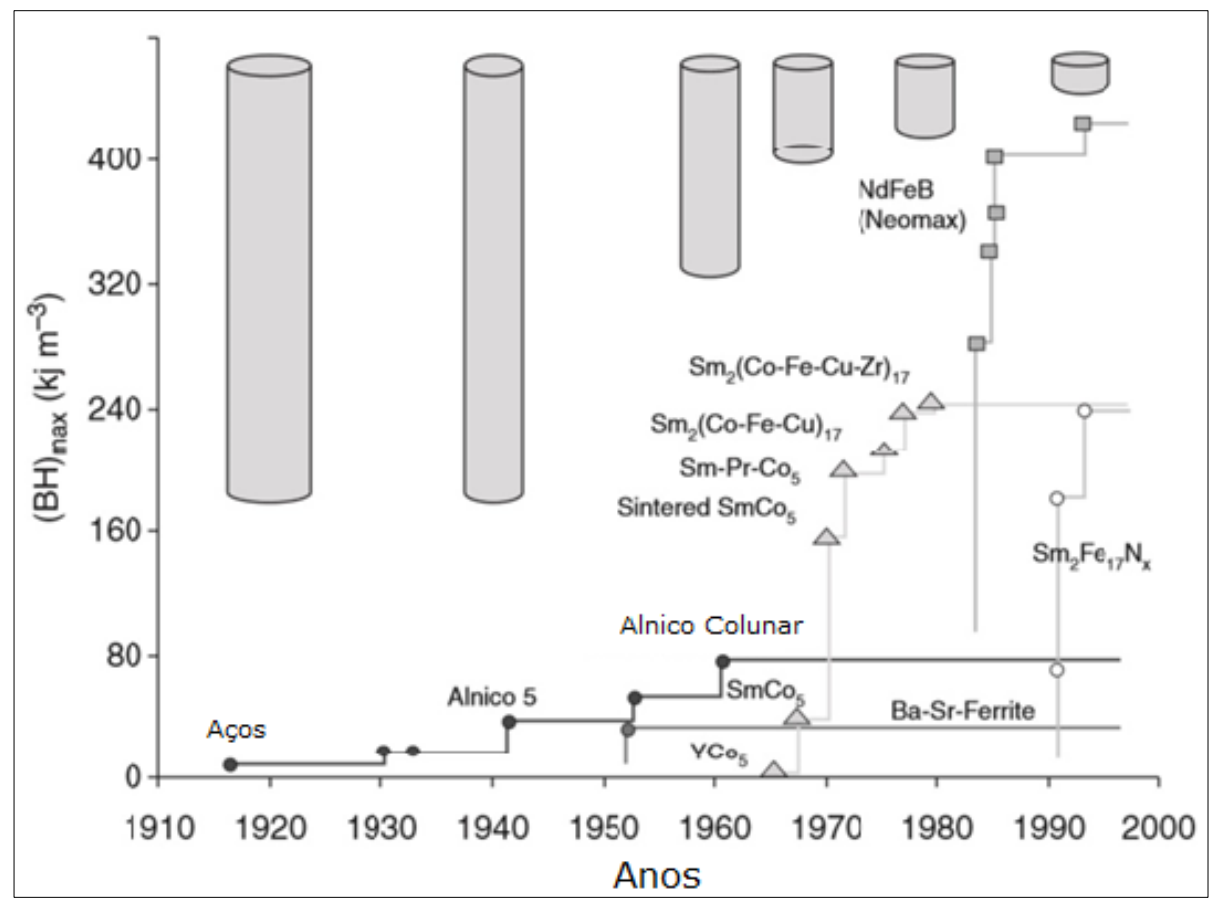

Fonte: Adaptado de [8].

Ao longo do século, os processos de produção e a descoberta de novos materiais magnéticos provocaram um aumento das propriedades magnéticas dos ímãs. Ao mesmo tempo em que os ímãs possuíam cada vez mais energia magnética armazenada, seu volume foi diminuindo na mesma proporção. Essas mudanças possibilitaram a criação de dispositivos eletrônicos cada vez menores e mais potentes [6-8]. 


\subsection{Terras-Raras: contexto atual e aplicações nos ímãs permanentes}

Os elementos terras-raras são aplicados em muitos setores industriais, como por exemplo, na produção de vidros e cerâmicos, como catalisadores no refino de petróleo, iluminação e metalurgia. A Tab.1 apresenta a porcentagem de elementos de terras-raras utilizada em cada aplicação [9].

Tabela 1: Utilização dos terras-raras por aplicação, dados em porcentagem (\%). Adaptado de [9]

\begin{tabular}{|c|c|c|c|c|c|c|c|c|c|c|}
\hline Aplicação & La & Ce & Pr & Nd & Sm & Eu & Gd & Tb & Dy & Y \\
\hline $\begin{array}{c}\text { Ímãs } \\
\text { permanentes }\end{array}$ & - & - & 23,4 & 69,4 & - & - & 2 & 0,2 & 5 & - \\
\hline $\begin{array}{c}\text { Ligas para } \\
\text { baterias }\end{array}$ & 50 & 33,4 & 3,3 & 10 & 3,3 & - & - & - & - & - \\
\hline $\begin{array}{c}\text { Metalurgia } \\
\text { relacionada à } \\
\text { baterias }\end{array}$ & 26 & 52 & 5,5 & 16,5 & - & - & - & - & - & - \\
\hline $\begin{array}{c}\text { Catalisadores } \\
\text { automotivos }\end{array}$ & 5 & 90 & 2 & 3 & - & - & - & - & - & - \\
\hline $\begin{array}{c}\text { Catalisadores } \\
\text { para refino de } \\
\text { combustível }\end{array}$ & 90 & 10 & - & - & - & - & - & - & - & - \\
\hline $\begin{array}{c}\text { Aditivos para } \\
\text { vidros }\end{array}$ & 24 & 66 & 1 & 3 & - & - & - & - & - & 2 \\
\hline $\begin{array}{c}\text { Fósforos } \\
\text { aplicações }\end{array}$ & 19 & 39 & 4 & 15 & 2 & - & 1 & - & - & 19 \\
\hline
\end{tabular}


Atualmente, a China é o maior produtor e exportador de elementos de terrasraras, dominando $90 \%$ do mercado e totalizando cerca de 55 milhões de toneladas em reservas. Em 2010, a China restringiu as exportações e aumentou o preço dos terras-raras, representando um risco ao abastecimento mundial [10].

Esse cenário promoveu uma procura por alternativas ao mercado chinês. O Brasil possui a segunda maior reserva desses elementos, totalizando 22 milhões de toneladas, tornando-o um forte candidato a participar do mercado de extração e separação de terras-raras, bem como na produção de ímãs permanentes [10].

A Tab.2 apresenta as reservas mundiais de terras-raras e a Fig.2 apresenta a distribuição das reservas de terras-raras no Brasil.

Tabela 2: Reservas mundiais de terras-raras [10].

\begin{tabular}{cc}
\hline País & Reservas (t) \\
\hline China & 55.000 .000 \\
Brasil & 22.000 .000 \\
Austrália & 3.200 .000 \\
Índia & 3.100 .000 \\
Estados Unidos & 1.800 .000 \\
Malásia & 30.000 \\
Outros países & 41.000 .000 \\
Total & 130.000 .000
\end{tabular}


Figura 2: Distribuição das reservas de terras-raras no Brasil.

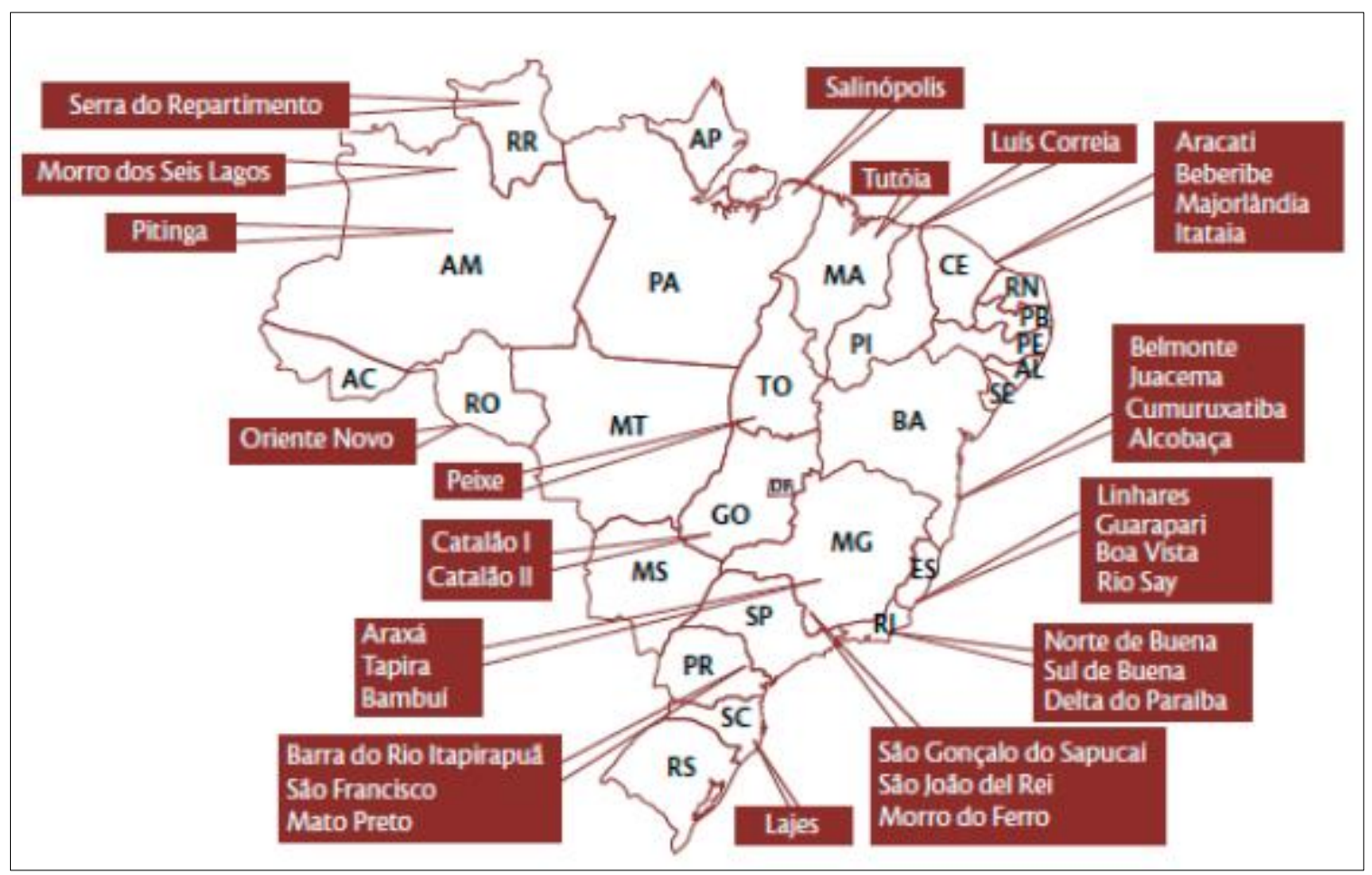

Fonte: [10].

\subsubsection{Aplicações dos ímãs permanentes de $\mathrm{NdFeB}$}

As aplicações dos ímãs permanentes de $\mathrm{NdFeB}$ são diversas, compreendendo desde separadores magnéticos aplicados na agricultura, na indústria farmacêutica e reciclagem, até aplicações no setor médico, como por exemplo, em equipamentos de ressonância magnética. Porém, a aplicação dos ímãs permanentes de $\mathrm{NdFeB}$ é majoritária no setor de motores elétricos para indústria automobilística e de geradores eólicos [11,17].

A demanda por ímãs permanentes de $\mathrm{NdFeB}$ irá crescer nas próximas décadas devido ao aumento na produção de geradores magnéticos e motores elétricos. Estima-se que em 2040, os veículos elétricos representem $1 / 3$ da frota mundial. Do ponto de vista ambiental, 8 milhões de barris de petróleo por dia deixarão de ser utilizados (número superior aos 7 milhões de barris de petróleo exportados diariamente pela Arábia Saudita)[11,12].

A Volvo declarou que a partir de 2019, produzirá apenas 3 tipos de veículos - 100\% elétricos, híbridos recarregáveis e os híbridos "leves", que combinarão um grande motor elétrico a um pequeno motor à gasolina. A meta é produzir 1 milhão de veículos destes tipos até 2025 [12-15]. 
Outra empresa surgiu recentemente com uma gama de veículos 100\% elétricos é a Tesla, que somente no ano de 2016 produziu 75 mil veículos elétricos. A Tesla apresentou planos de produção de 1 milhão de veículos elétricos por ano à partir de 2020 [12-15] .

O Reino Unido e a França anunciaram recentemente que irão banir todos os veículos de motores à combustão até 2040, seguidos por outros países europeus como a Holanda e Noruega (estima-se que até 2025 estes dois países possuam $100 \%$ de sua frota composta por veículos elétricos), pela Índia e China, que pretende extinguir tais veículos até 2050 [12-15].

Considerando que, em média, 1 kg de ímãs permanentes de NdFeB são utilizados apenas no motor de um veículo elétrico, a demanda será de 150 mil toneladas destes ímãs para esta aplicação em 2050 [11,15].

Outra aplicação extremamente importante dos ímãs permanentes de NdFeB são nos geradores eólicos. Na mesma proporção do setor automobilístico, a substituição de fontes emissoras de $\mathrm{CO}_{2}$ para a produção de energia elétrica também aumenta a cada ano. A previsão para o ano de 2017 é que sejam instalados $60 \mathrm{GW}$ eólicos mundialmente, e que em 2021 atinja-se a marca de 800 GW eólicos globalmente, representando o dobro da energia atual [16].

O Brasil ocupa o $9^{\circ}$ lugar no ranking global em potência eólica instalada, chegando à marca de 10,7 GW eólicos, reduzindo as emissões de $\mathrm{CO}_{2}$ em 16 milhões de toneladas por ano [16].

Estima-se que a capacidade global em 2050 seja de 2500 GW eólicos. Considerando que cada gerador eólico utilize cerca de $600 \mathrm{~kg}$ de ímãs permanentes de NdFeB por cada mega-watt gerado, serão necessários cerca de 2 milhões de toneladas de ímãs permanentes de NdFeB em 2050 [11,16].

A utilização dos ímãs permanentes de NdFeB nos geradores eólicos permite que esses sistemas sejam cada vez menores e mais potentes. As Figs.3 e 4 apresentam exemplos das aplicações dos ímãs de NdFeB em geradores magnéticos de turbinas eólicas e em motores de veículos elétricos e híbridos, respectivamente. 
Figura 3: Gerador magnético de uma turbina eólica.

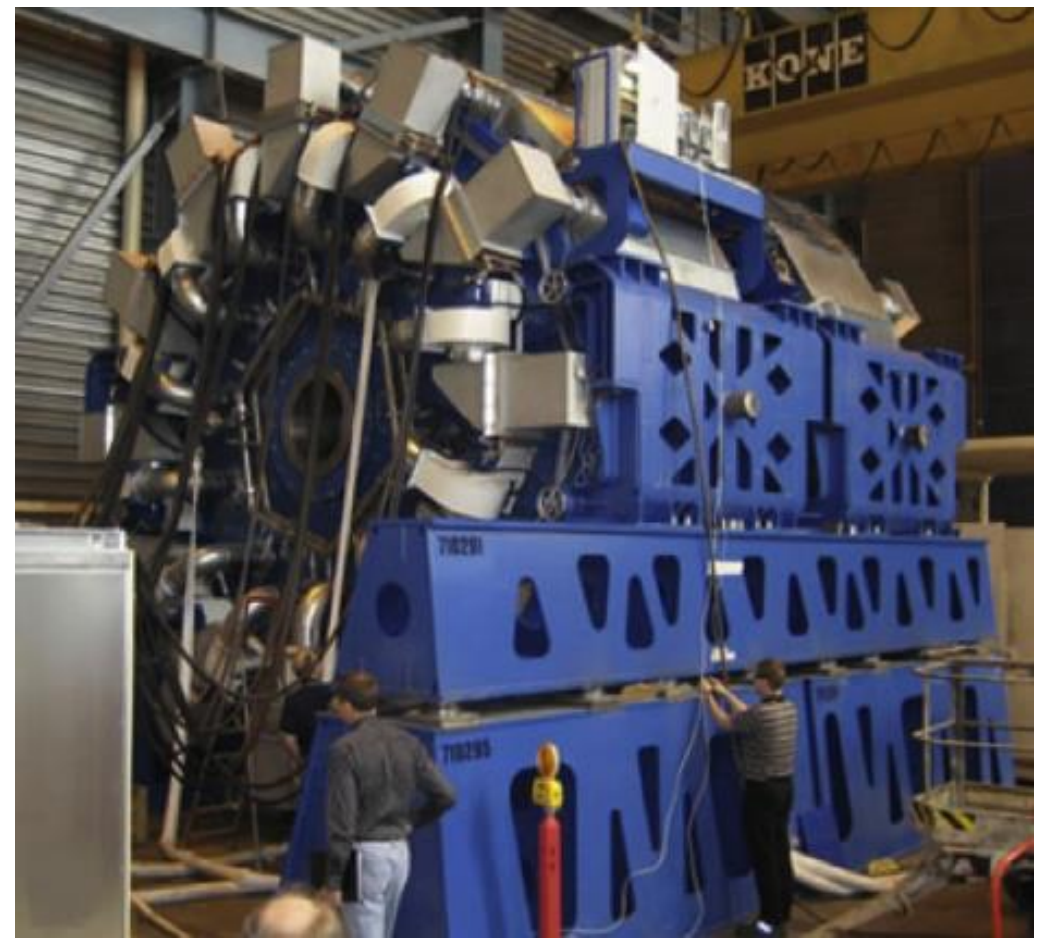

Fonte: [17].

Figura 4: Ímãs permanentes em um motor de um veículo elétrico (Toyota Prius).

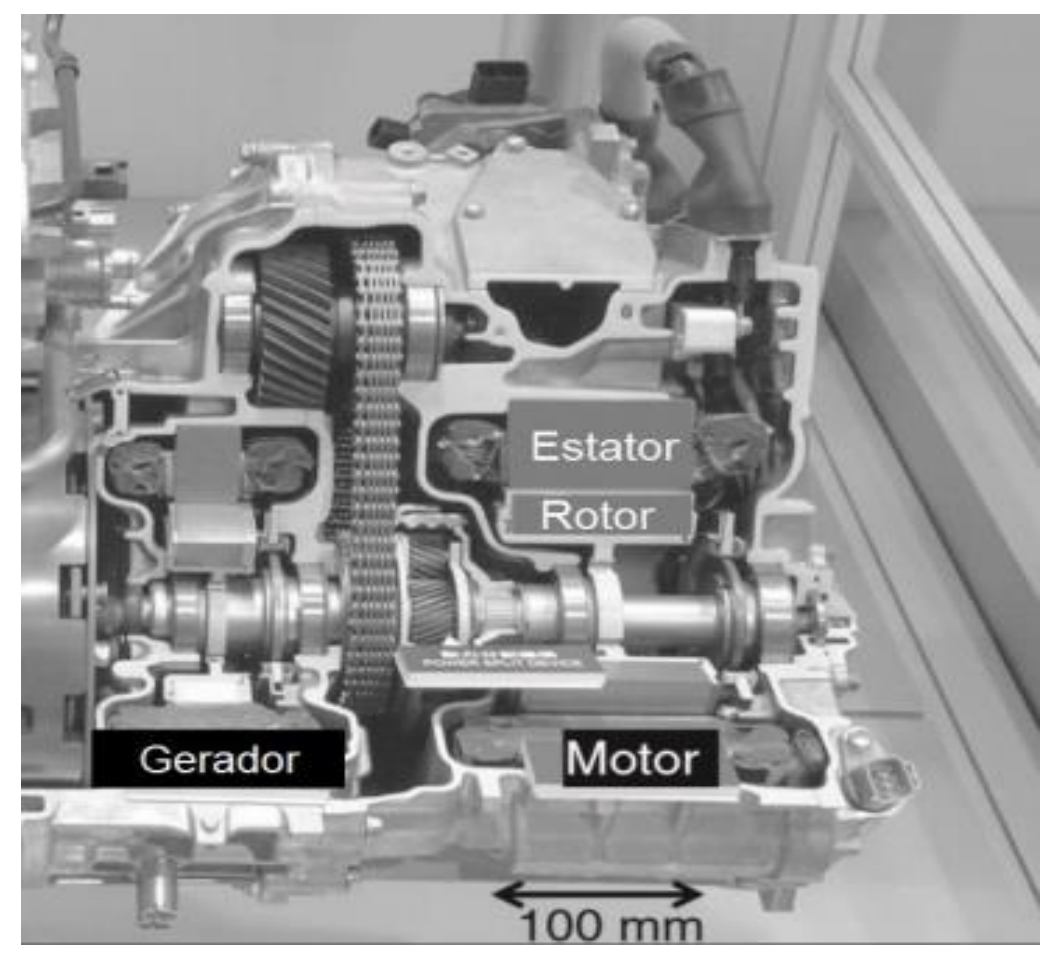

Fonte 1: Adaptado de [8]. 


\subsubsection{O uso de terras-raras pesados na produção dos ímãs permanentes}

Apesar das propriedades magnéticas dos ímãs de NdFeB serem superiores aos antecessores compostos por $\mathrm{SmCo}$, a estabilidade térmica do $\mathrm{NdFeB}$ é um fator determinante na sua aplicação. A temperatura de Curie dos ímãs de NdFeB localiza-se em torno de $350^{\circ} \mathrm{C}$, enquanto que para os compostos de Sm-Co esta temperatura localiza-se em torno de $750^{\circ} \mathrm{C}$ [11].

Um dos grandes problemas dos ímãs de NdFeB é a degradação acentuada da coercividade com o aumento da temperatura. Por causa disso, as aplicações desses ímãs se limitam à temperaturas de até $100^{\circ} \mathrm{C}$ [11].

Um dos métodos mais utilizados para evitar a degradação da coercividade à altas temperaturas é a adição de terras-raras pesados, como o disprósio (Dy) ou térbio $(\mathrm{Tb})$ na composição NdFeB. Adições de disprósio (cerca de 5\% em massa) aumentam significativamente a anisotropia magnetocristalina da fase magnética $\mathrm{Nd}_{2} \mathrm{Fe}_{14} \mathrm{~B}$, compensando o efeito negativo da temperatura [11].

Porém o uso do disprósio tem muitas desvantagens, uma vez que este elemento está em estado crítico na natureza e encarece muito a produção dos ímãs à base de NdFeB. Muitos esforços têm sido realizados para reduzir ou até eliminar o disprósio da composição dos ímãs de NdFeB [11].

Um dos métodos para reduzir o uso do disprósio é a deposição localizada de pequenas quantidades de Dy na superfície do material e promover um ciclo de tratamento térmico para a difusão. Esse método é conhecido como Grain Boundary Diffusion. Este processo permite utilizar teores muito reduzidos de Dy (cerca de 1\% em massa) [11].

Outro método é o controle microestrutural. O tamanho de grão do material exerce muita influência sobre as propriedades magnéticas, principalmente na coercividade. O controle e o refino da microestrutura pode ser realizado a partir da deformação à quente do material, da adição de elementos refinadores de microestrutura, como por exemplo o nióbio e otimizando parâmetros do processo de moagem [11]. 


\section{OBJETIVO}

O objetivo do presente trabalho é a obtenção de ímãs permanentes sinterizados à base de $(\mathrm{Nd}, \mathrm{Pr}) \mathrm{FeB}$ produzidos via rota convencional de metalurgia do pó a partir de diferentes tempos de moagem de alta energia para estudar a influência deste parâmetro na microestrutura e nas propriedades magnéticas.

\section{REVISÃO DE LITERATURA}

Para uma melhor compreensão do trabalho, a revisão de alguns conceitos relacionados aos materiais magnéticos e seu processamento torna-se necessária. Além disso, uma revisão sobre os trabalhos publicados na área relacionados à moagem de alta energia na produção de ímãs permanentes de terras-raras-ferroboro também será apresentada a seguir.

\subsection{Propriedades magnéticas dos materiais}

\subsubsection{Campo magnético}

Uma das ideias mais fundamentais do magnetismo é o conceito de campo magnético. Não existe uma definição concreta do que é campo magnético, porém esse conceito pode ser definido como a força exercida sobre uma carga elétrica no espaço [18-20].

Campos magnéticos são produzidos por cargas elétricas em movimentos. A lei de Biot-Savart permite que seja calculado o campo magnético $H$ gerado por uma corrente elétrica i por um fio de comprimento $I$, pela equação 1 [18-20]:

$$
\delta H=\frac{1}{4 \pi r^{2}} i \delta l \times u[\mathrm{~A} / \mathrm{m}]
$$

O campo magnético é expresso em termos de ampère por metro, o que significa que uma corrente elétrica de 1 ampère percorrendo um fio condutor de 1 metro gera um campo magnético tangencial de $1 / 4 \pi$ ampères por metro à uma distância radial de 1 metro [18-20].

\subsubsection{Momento magnético}

Quando uma corrente elétrica $i$ percorre um condutor de área $A$, o momento magnético $m$ gerado é expresso por [18-20]: 


$$
m=i . A[\mathrm{~A} / \mathrm{m}]
$$

onde o momento magnético é expresso por ampères por metro. Momento magnético também pode ser definido como sendo o torque que um dipolo magnético está sujeito quando exposto à um campo magnético, expresso pela equação 3 [18-20]:

$$
m=\frac{\tau_{\text {máx }}}{B} \quad[\mathrm{~A} / \mathrm{m}]
$$

Considerando o modelo atômico de Bohr, elétrons transladando em torno do núcleo atômico é uma fonte geradora de campo magnético. Além disso, o movimento de rotação dos elétrons em relação ao seu eixo (spin) também é uma fonte de campo magnético. A combinação destes dois fenômenos resulta em um momento magnético, produzindo um campo magnético externo (ou indução magnética B) exibido por muitos materiais, mesmo na ausência de um campo magnético externo $(\mathrm{H})$ [18-20].

\subsubsection{Dipolo magnético}

Ao dividirmos um ímã ao meio, cada uma das metades irá apresentar as mesmas características do ímã original, possuindo os polos norte e sul. Se continuarmos a dividir cada metade, chegaríamos à espécies infinitesimais que não poderiam mais ser divididas. Essas espécies são chamadas de ímãs elementares [18-20].

Isso faz com que a unidade fundamental do magnetismo seja o dipolo magnético [18-20].

\subsubsection{Magnetização e Indução Magnética}

A magnetização de um material $M$ pode ser definida como o momento magnético por volume em um sólido, expresso pela equação 4 [18-20]:

$$
M=\frac{m}{V}
$$


Relacionando o momento magnético $m$ com o fluxo magnético $\Phi$, pode-se achar uma correlação entre magnetização $M$ e indução magnética $B$. A magnetização pode ser pela equação 5 [18-20]:

$$
M=\frac{\Phi}{\mu_{0} A}
$$

e a indução magnética $B$ sendo definida como [18-20]:

$$
B=\frac{\Phi}{A}
$$

pode-se relacionar a magnetização $M$ e a indução magnética $B$ pela expressão 7 [18-20]:

$$
M=\frac{B}{\mu_{0}}
$$

A indução magnética $B$ consiste de duas contribuições: uma do campo magnético $H$ e outra da magnetização $M$. A indução magnética é uma simples soma vetorial de $H$ e $M$, expressa pela equação 8 [18-20]:

$$
B=\mu_{0}(H+M)[T]
$$

Onde $B$ é dado em tesla $(\mathrm{T}), H$ e $M$ são dados em ampère por metro $(\mathrm{A} / \mathrm{m}) \mathrm{e}$ $\mu_{0}=4 \pi \cdot 10^{-7}(\mathrm{~T} \cdot \mathrm{m} / \mathrm{A})[18-20]$.

\subsubsection{Permeabilidade e Susceptibilidade Magnética}

Os materiais podem ser classificados de acordo com o seu comportamento frente um campo magnético externo. Existem duas grandezas que classificam esse comportamento, que são chamadas de permeabilidade magnética $(\mu)$ e susceptibilidade magnética $(X)$. A primeira mensura o campo magnético no interior de um material e a segunda mensura a capacidade de um material se magnetizar [18-20]. 
A permeabilidade e a susceptibilidade magnética são expressas pelas equações 9 e 10 [18-20]:

$$
\begin{aligned}
& \mu=\frac{B}{H} \\
& \chi=\frac{M}{H}
\end{aligned}
$$

Tanto a permeabilidade magnética quanto a susceptibilidade magnética variam de acordo com o material [18-20].

\subsubsection{Classificação dos Materiais}

Como dito no tópico anterior, os materiais são classificados de acordo com a permeabilidade e susceptibilidade magnética. Os materiais podem ser classificados em [18-20]:

- Materiais Ferromagnéticos: Esses materiais apresentam susceptibilidades positivas e muito maiores do que $1, x \approx 50$ a 10.000. Quando um campo externo é aplicado, os momentos magnéticos se alinham paralelamente ao campo aplicado e permanecem orientados mesmo após a retirada do campo. Esses materiais perdem seu alinhamento quando são elevados à uma temperatura crítica, conhecida como temperatura de Curie. Alguns exemplos de materiais ferromagnéticos são o ferro, cobalto e níquel.

- Materiais Paramagnéticos: Esses materiais apresentam susceptibilidades magnéticas positivas, porém muito pequenas, $x \approx 10^{-3}$ a $10^{-5}$. Essa classe de material possui um número ímpar de elétrons desemparelhados, que quando submetidos a um campo externo, magnetizam-se fracamente e produzem seu próprio campo magnético, de forma paralela ao campo externo aplicado. Exemplos de elementos desta classe são a platina, alumínio, oxigênio e muitos sais dos metais de transição. 
- Materiais Diamagnéticos: São materiais que possuem uma susceptibilidade muito pequena e negativa, $X \approx-10^{-5}$. Essa classe de material não exibe campo magnético externo, pois não possuem elétrons desemparelhados. Porém, o movimento dos elétrons ao redor dos núcleos atômicos produz um campo magnético interno. Quando submetidos a um campo magnético externo, esses materiais tendem a se afastar da região onde esse campo é mais forte. Materiais como o ouro, prata, cobre, berílio e bismuto são exemplos dessa classe.

- Materiais Ferrimagnéticos: É uma variação dos materiais ferromagnéticos. Essa classe apresenta dois tipos de momentos magnéticos diferentes. Uma parte desses momentos magnéticos se alinha de forma antiparalela ao campo magnético externo, porém o outro tipo de momento magnético se alinha de forma paralela, produzindo uma resultante não nula. Os ferrítes são um exemplo.

- Materiais Antiferromagnéticos: Também é uma variação dos materiais ferromagnéticos. Quando são expostos a um campo magnético externo, os momentos magnéticos alinham-se de forma antiparalela, resultantes de interações de troca entre átomos vizinhos. Essa configuração resulta em um campo magnético externo muito pequeno ou nulo.

\subsubsection{Os Domínios Magnéticos e as Paredes de Bloch}

Domínios magnéticos são regiões onde os dipolos magnéticos estão alinhados espontaneamente em uma direção preferencial. Essas regiões ocorrem em materiais ferromagnéticos e dependem dos elétrons desemparelhados dos átom os. Materiais como o ferro, o cobalto, o níquel e ligas destes elementos com alguns terras-raras possuem esta estrutura de domínios magnéticos [18-20].

Em um material policristalino, cada grão do material pode conter mais do que um domínio magnético. Quando o material está desmagnetizado, os domínios magnéticos estão alinhados de forma aleatória, diminuindo a energia global do sistema. Quando o material é submetido a um campo magnético externo, esses domínios magnéticos respondem a esse campo, alinhando-se paralelamente ao campo aplicado, aumentando a energia do sistema [18-20]. 
Quando o material alinhado é aquecido, os domínios magnéticos começam a desorientarem-se e este estado de desordem é proporcional ao aumento da temperatura. O estado ferromagnético desaparece à uma temperatura específica devido à desordem térmica progressiva. Esta temperatura é chamada de temperatura de Curie $\left(T_{c}\right)$ [18-20].

As regiões de interface entre domínios magnéticos são chamadas de paredes de domínio ou paredes de Bloch. Durante o processo de magnetização do material, a orientação dos domínios magnéticos ocorre de forma gradual conforme as paredes de Bloch se movimentam. A Fig.5 esquematiza o processo de magnetização [18-20].

Figura 5: Movimentação dos domínios magnéticos e das paredes de Bloch.

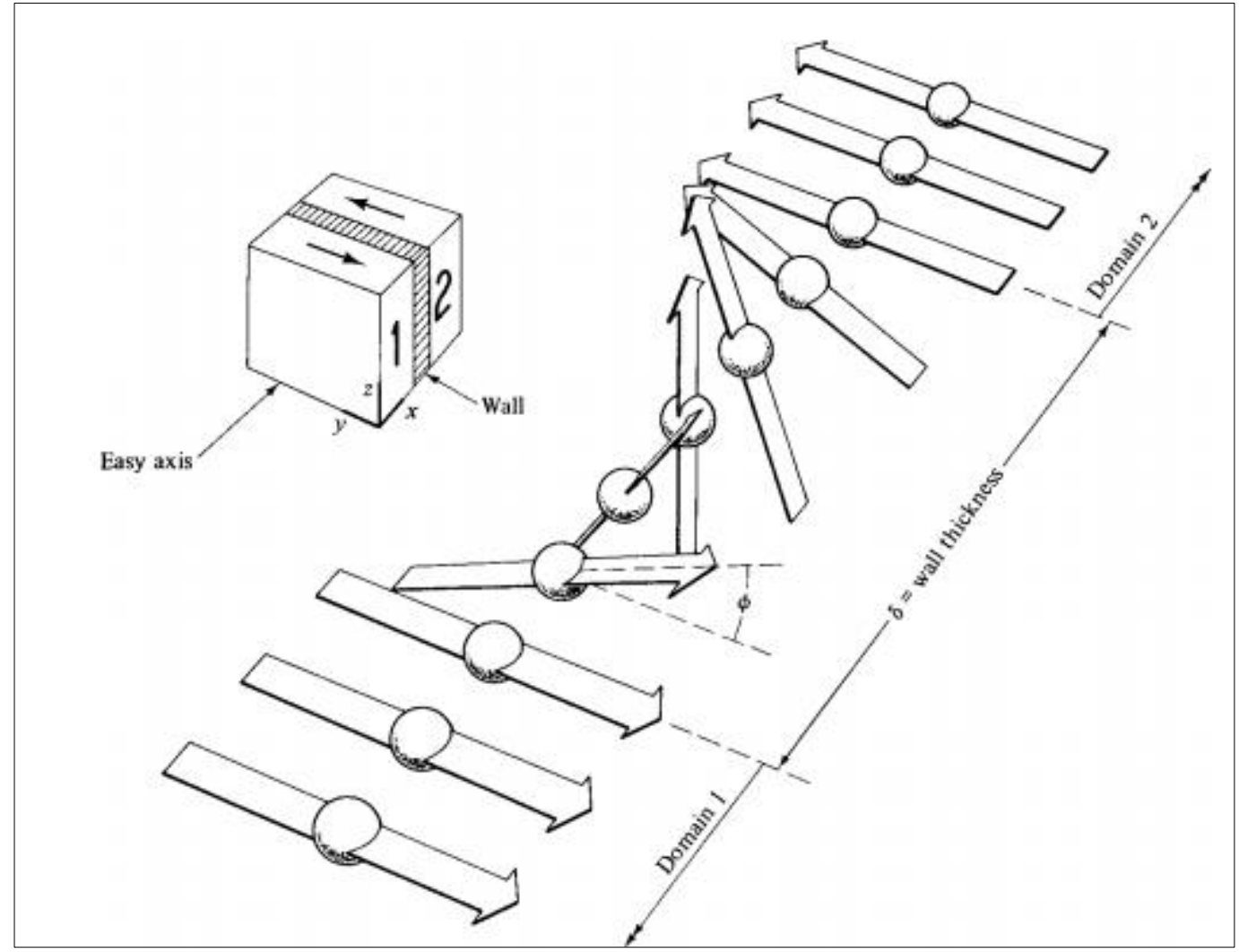

Fonte: [19].

Os domínios que estão alinhados paralelamente com o campo externo crescem às custas dos domínios desalinhados, até que prevaleça a presença de um único domínio magnético no material alinhado ao campo externo. Quando esse domínio é formado, diz-se que o material atingiu a magnetização de 
saturação $\left(M_{s}\right)$ ou polarização de saturação $\left(J_{s}\right)$. A Fig.6 apresenta este processo. [18-20].

Figura 6: Processo de saturação magnética de um material ferromagnético.

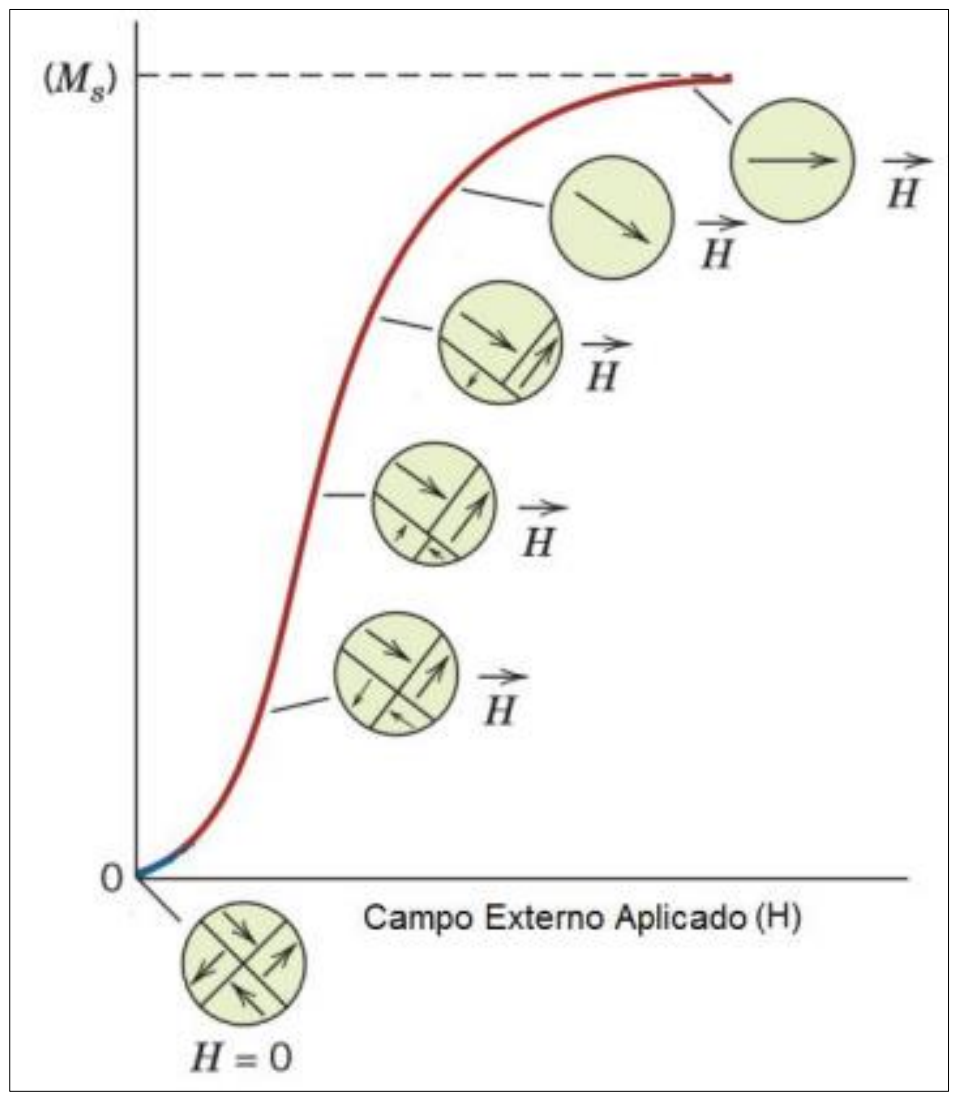

Fonte: [21]

Quando um material ferromagnético atinge a saturação completa e o campo magnético externo é retirado, observa-se que o fluxo magnético $B$ não se torna zero.

\subsubsection{Anisotropia Magnetocristalina}

O termo anisotropia magnética é usado para descrever a dependência da energia interna do material na direção da magnetização espontânea, energia essa chamada de energia anisotrópica magnética. Em geral, a energia anisotrópica magnética tem a mesma simetria da estrutura cristalina do material, e é conhecida como anisotropia magnetocristalina[18-20].

Em termos gerais, a anisotropia magnetocristalina depende do acoplamento entre os spins e os momentos orbitais dos elétrons nos átomos [18-20]. 
No caso de metais como o ferro, cobalto e níquel, o acoplamento spin-orbital dos elétrons $3 d$ é fraco. Por outro lado, os elementos de terras-raras apresentam o um acoplamento muito mais intenso de seus spins $4 \mathrm{f}$, gerando uma anisotropia magnetocristalina maior [18-20].

A consequência desse acoplamento spin-orbital é o surgimento de uma direção de fácil magnetização dentro de uma estrutura cristalina. Tomando como exemplo o ferro, que se cristaliza no sistema cúbico, apresenta três eixos cristalográficos. O eixo preferencial de magnetização no sistema cúbico é o eixo $c$ da estrutura cristalina [18-20].

Para alinhar a magnetização em um eixo menos favorável (eixo de difícil magnetização) é necessária uma quantidade de energia. A diferença de energia entre a magnetização no eixo preferencial e na direção de difícil magnetização é chamada de anisotropia magnetocristalina [18-20].

A anisotropia magnetocristalina pode ser calculada a partir da expansão [1820]:

$$
E=K_{1} \operatorname{sen}^{2} \theta+K_{2} \operatorname{sen}^{4} \theta+K_{3} \operatorname{sen}^{6} \theta+\ldots
$$

Onde $K_{1}$ e $K_{2}$ são constantes anisotrópicas e $\theta$ é o ângulo entre o eixo de fácil magnetização e o eixo $c$ da estrutura cristalina. Na prática, apenas $K_{1}$ é considerado para avaliar a anisotropia magnetocristalina [18-20].

Se as constantes $K_{1}$ e $K_{2}$ são positivas, significa que a magnetização espontânea para um determinado $\theta$ é estável e essa direção de magnetização é chamada de eixo de fácil magnetização. Se $K_{1}$ e $K_{2}$ forem negativos, a magnetização é instável para um determinado $\theta$ e essa direção é chamada de eixo de difícil magnetização [18-20].

Outra grandeza utilizada para descrever a anisotropia é o campo anisotrópico $\left(\mathrm{H}_{\mathrm{A}}\right)$, que representa o campo necessário para mover a magnetização do eixo fácil para outro eixo determinado. O campo anisotrópico é descrito por [18-20]:

$$
H_{A}=\frac{2 K_{1}}{\mu_{0} M_{S}}
$$


Onde $M_{s}$ é a magnetização de saturação para a direção especificada a uma determinada temperatura [18-20].

Apesar do fenômeno de crescimento dos domínios magnéticos não ser afetado pela anisotropia magnetocristalina, a rotação incoerente (irreversível) e coerente (reversível) dos domínios magnéticos é determinada principalmente pela anisotropia magnetocristalina. É por esse motivo que muitos materiais - os ímãs permanentes, por exemplo - produzem seu próprio campo magnético após a retirada de um campo magnético externo [18-20].

\subsection{O Ciclo de Histerese}

Quando um material ferromagnético é exposto a um campo magnético externo variante $(H)$, exibe uma resposta em termos de indução magnética $(B)$ em função deste campo. Uma relação entre H e B pode ser descrita por um gráfico, que é chamado de curva de histerese [18-20].

A Fig.7 representa o ciclo de histerese de um material ferromagnético. 
Figura 7: Ciclo de histerese de um material ferromagnético.

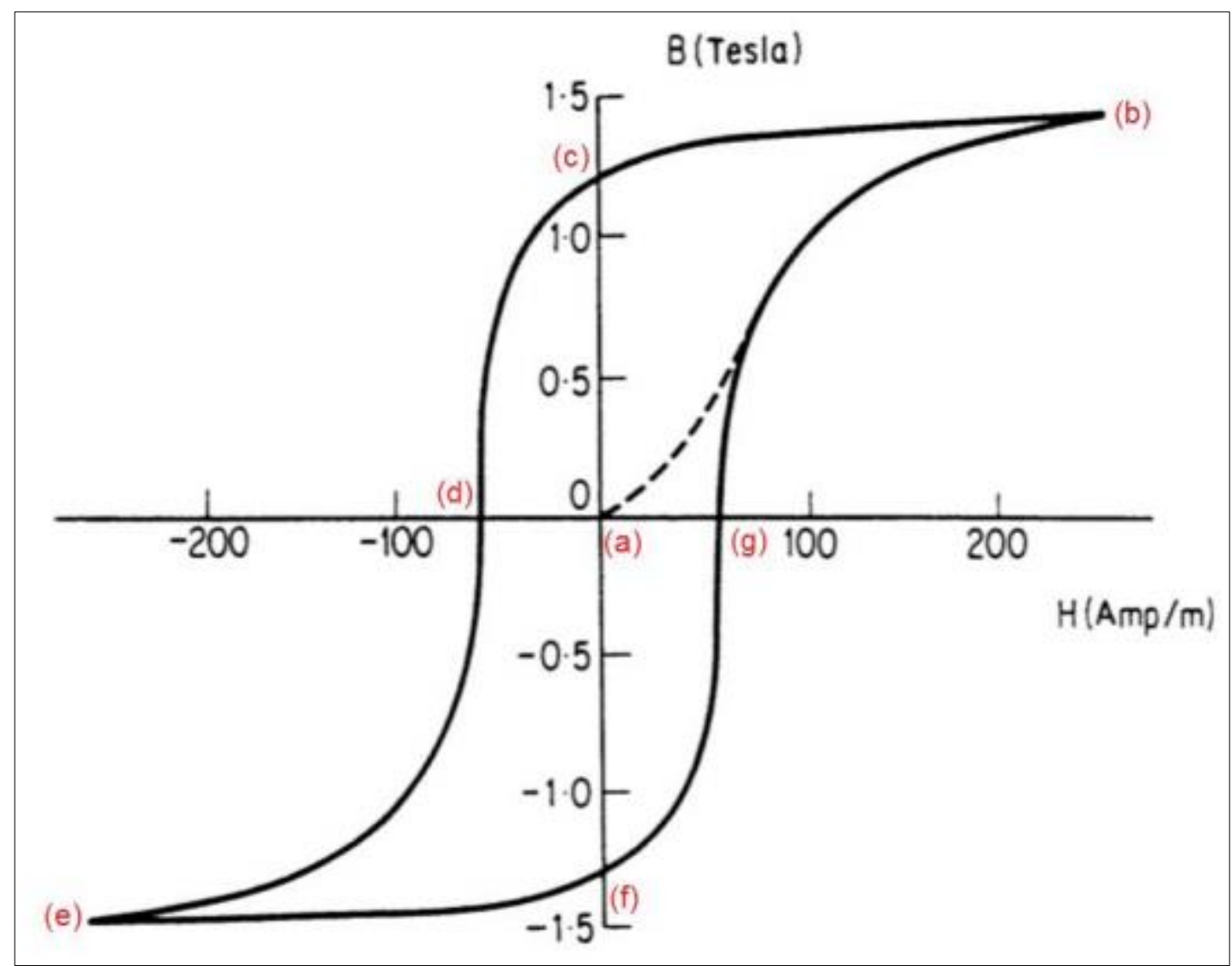

Fonte: Adaptado de [18]. 
A curva tracejada no primeiro quadrante do ciclo de histerese representa o processo de magnetização de saturação. No ponto (a), o campo externo aplicado H é zero. Neste ponto, os domínios magnéticos do material estão desalinhados.

Conforme a intensidade do campo externo aplicado aumenta, chega-se no ponto (b), que representa a magnetização de saturação $\left(M_{s}\right)$ do material. Quando o campo externo é retirado, chega-se ao ponto (c), que representa a remanência $\left(B_{r}\right)$ do material, que é o campo magnético remanescente no material [18-20].

Aplicando um campo externo desmagnetizante $(-\mathrm{H})$, o ponto (d) é alcançado, representando a coercividade intrínseca $\left({ }_{\mathrm{i}} \mathrm{H}_{\mathrm{c}}\right)$. Este ponto indica a intensidade de campo desmagnetizante necessário para reduzir a indução magnética a zero [1820].

Continuando com a aplicação do campo desmagnetizante $(-\mathrm{H})$, o ponto (e) é alcançado, representando a magnetização de saturação do material, porém com a polaridade inversa observada no ponto (a). De forma análoga, o processo repetese nos pontos (f) e (g), formando o ciclo de histerese completo [18-20].

O segundo quadrante da curva de histerese compreendido entre os pontos (c) e (d) é o quadrante mais utilizado para obter as propriedades magnéticas dos materiais. A Fig.8 apresenta de forma mais detalhada a curva de desmagnetização, com a indicação das propriedades magnéticas obtidas a partir da mesma [18-20]. 
Figura 8: Curva de desmagnetização de um ímã permanente.

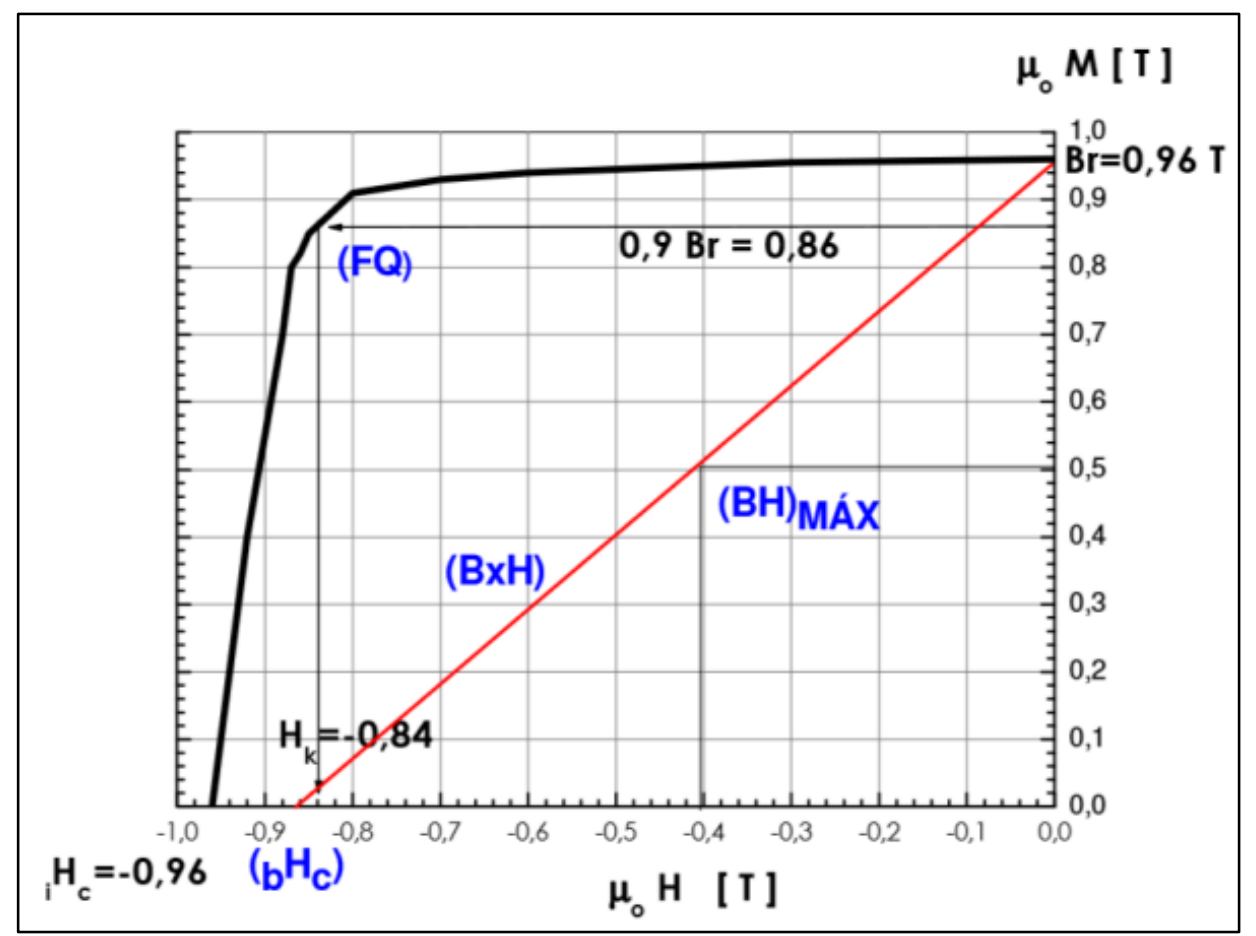

Fonte: [22].

Da curva de desmagnetização, além da remanência $\left(B_{r}\right)$ e da coercividade intrínseca $\left(\mathrm{H}_{\mathrm{C}}\right)$, obtém-se também a coercividade indutiva $\left({ }_{\mathrm{b}} \mathrm{H}_{\mathrm{c}}\right)$, produto de energia máximo $\left((\mathrm{BH})_{\mathrm{MÁx}}\right)$ e o fator de quadratura (FQ). As propriedades magnéticas são explicadas de forma mais detalhada a seguir [22]:

Remanência $\left(B_{r}\right)$ : indica o campo magnético residual armazenado no material após ter sido magnetizado até sua saturação quando o campo magnético externo é retirado.

A remanência depende de fatores intrínsecos de cada material como, por exemplo, a magnetização de saturação $\left(\mathrm{M}_{\mathrm{s}}\right)$, e de fatores microestruturais, como o grau de textura do material $(<\cos \theta>)$, da densidade relativa do material $(\mathrm{P})$ e da fração volumétrica de grãos magnéticos (f). A remanência é expressa em tesla $(T)$ no Sistema Internacional. A remanência pode ser calculada pela equação (11) [18-22]:

$$
B_{r}=<\cos \theta>f P \mu_{0} M_{s}[\mathrm{~T}]
$$


Onde $\mu_{0}=4 \pi \cdot 10^{-7} \mathrm{~T} \cdot \mathrm{m} \cdot \mathrm{A}^{-1}$ é a permeabilidade magnética no vácuo.

Coercividade Intrínseca $\left({ }_{\mathrm{i}} \mathrm{H}_{\mathrm{c}}\right)$ : indica a resistência que o material oferece frente a desmagnetização. Quanto maior a coercividade intrínseca maior será o campo reverso necessário para desmagnetizar o material. No Sistema Internacional, a coercividade intrínseca é expressa em ampère por metro $(\mathrm{A} / \mathrm{m})$, e pode ser calculada pela equação (12) [18-22]:

$$
\mu_{o} i H c=c \mu_{0} H_{A}-N \mu_{0} M_{S}[\mathrm{KA} / \mathrm{m}]
$$

A coercividade intrínseca também depende de fatores microestruturais como, por exemplo, distribuição de tamanho de grão. Essa dependência é representada pelos fatores $c$ e $N$. Também é proporcional ao campo anisotrópico $\left(\mathrm{H}_{\mathrm{A}}\right)[18-22]$.

Coercividade Indutiva $\left({ }_{b} H_{c}\right)$ : indica o campo magnético necessário para reduzir a indução magnética à zero [18-22].

Produto de Energia Máximo ((BH) $)_{\text {MÁx }}$ : indica o maior valor máximo de energia magnética armazenada por volume de material. Esse valor é obtido realizando a multiplicação de valores de indução magnética pelo campo desmagnetizante, na curva de desmagnetização. Esta propriedade é inversamente proporcional ao volume de material e é, com frequência, utilizado como parâmetro de qualidade de um ímã. No Sistema Internacional, é expresso em joules por metro cúbico $\left(\mathrm{J} / \mathrm{m}^{3}\right)$ [18-22].

Fator de Quadratura (FQ): é um parâmetro que reflete a estabilidade de um ímã frente a um campo desmagnetizante. Físicamente representa o número de grãos magnéticos que reverteram sua magnetização para um mesmo valor de campo externo aplicado. Este fator está intimamente relacionado à microestrutura, podendo ser afetado pela distribuição de grãos e sua homogeneidade e pela presença de fases magneticamente moles presentes. Uma microestrutura mais homogênea eleva os valores de fator de quadratura [18-22]. 
O fator de quadratura é obtido pela equação (13):

$$
F Q=\frac{H_{K}}{i H c}
$$

Onde $\mathrm{H}_{\mathrm{K}}$ representa o valor do campo desmagnetizante responsável pela redução de 10\% da remanência [18-22].

\subsection{O processo de Decrepitação por Hidrogênio (HD)}

O uso do hidrogênio no processamento dos ímãs de terras-raras foi primeiramente introduzido na produção dos ímãs de $\mathrm{SmCo}_{5}$, iniciado por Harris e colaboradores em 1978. O processo de absorção e eliminação de hidrogênio antecedia as etapas de alinhamento magnético e compactação [23].

Posteriormente, a decrepitação por hidrogênio estendeu-se para a produção de ímãs de composição $\mathrm{Sm}_{2} \mathrm{Co}_{17}$. Para esta composição verificou-se a necessidade da combinação entre altas temperaturas (cerca de $200^{\circ} \mathrm{C}$ ) e altas pressões de hidrogênio [23].

Após o desenvolvimento das ligas ternárias compostas por TR-Fe-B, os estudos sobre o comportamento deste material sob atmosfera de hidrogênio se iniciaram.

Harris e colaboradores estudaram o comportamento da liga $\mathrm{Nd}_{15} \mathrm{Fe}_{77} \mathrm{~B}_{8}$ no processo de hidrogenação a uma pressão de 33 bar e temperatura ambiente. Verificou-se que o processo de absorção de hidrogênio era realizado em duas etapas, primeiramente pela fase de contornos de grão e posteriormente pela fase matriz $\mathrm{Nd}_{2} \mathrm{Fe}_{14} \mathrm{~B}$. A absorção de hidrogênio pela fase matriz causa uma expansão do seu retículo cristalino. A Fig.9 apresenta o esquema deste processo [24].

A eliminação de hidrogênio também foi estudada para uma amostra em pó. Verificou-se que para uma faixa de temperaturas entre $423 \mathrm{~K}$ e $533 \mathrm{~K}\left(150^{\circ} \mathrm{C}\right.$ e $260^{\circ} \mathrm{C}$ ), ocorria a primeira etapa de eliminação de hidrogênio da liga $\mathrm{Nd}_{15} \mathrm{Fe}_{77} \mathrm{~B}_{8}$, proveniente da fase matriz. Numa faixa de temperaturas mais alta, compreendida entre $623 \mathrm{~K}$ e $923 \mathrm{~K}\left(350^{\circ} \mathrm{C}\right.$ e $\left.650^{\circ} \mathrm{C}\right)$, observou-se a segunda etapa de eliminação de hidrogênio, proveniente da fase rica em Nd (localizada nos contornos de grão) [24]. 
Figura 9: Processo de dcrepitação por hidrogênio (HD).

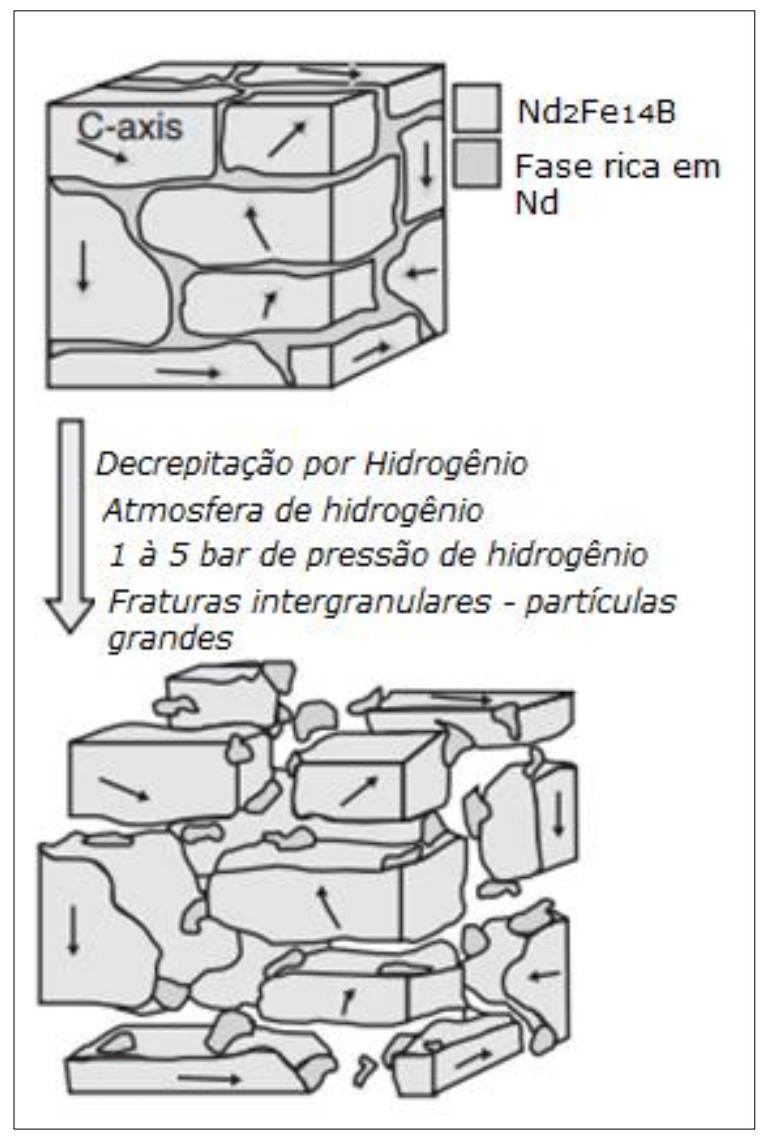

Fonte: Adaptado de [8].

O efeito do hidrogênio absorvido nas propriedades magnéticas da fase $\mathrm{TR}_{2} \mathrm{Fe}_{14} \mathrm{~B}(\mathrm{TR}=\mathrm{Ce}, \mathrm{Pr}, \mathrm{Nd}, \mathrm{Sm}$ ou $\mathrm{Y})$ foi estudado por Pourarian e colaboradores [25]. Foi constatado que os compostos estudados absorvem cerca de 4,4 a 6 átomos de hidrogênio por fórmula unitária, acompanhada de sua expansão volumétrica que varia entre $4 \%$ e $6 \%$. O hidrogênio absorvido provoca um aumento do momento magnético dos átomos de $\mathrm{Fe}$, em todos os hidretos estudados. Também exercia influência na direção de fácil magnetização (à temperatura ambiente) dos compostos contendo $\mathrm{Y}$ e $\operatorname{Pr}$ [25].

As fases $\mathrm{Nd}_{2} \mathrm{Fe}_{14} \mathrm{~B}$ e $\mathrm{Ce}_{2} \mathrm{Fe}_{14} \mathrm{~B}$ tiveram uma redução da anisotropia magnetocristalina, indicando que a anisotropia do ferro e dos elementos terrasraras é alterada na presença de hidrogênio.

Harris e McGuiness descrevem o uso do hidrogênio no processamento dos ímãs do tipo TR-Fe-B. Os autores relacionam o estado inicial da matéria-prima e o pó resultante do HD [26]. 
Caso a liga contenha grandes teores de fase de ferro- $\alpha$, partículas em formato de "flake" são obtidas após o HD. Os autores descrevem que esse processo é devido ao grau de ductilidade que a matéria-prima apresenta. hidrogênio se difunde até uma determinada profundidade e devido à variação volumétrica associada com a solubilidade do hidrogênio, fraturas ocorrem gerando partículas em formado de "flake" [26].

Caso a matéria-prima esteja homogeneizada, a fase de ferro- $\alpha$ não existirá na liga, de tal forma que o processo HD não vai gerar uma partícula em formato de "flake", devido ao aspecto mais frágil da liga [26].

As reações químicas provenientes da reação de hidrogenação para compostos de NdFeB são [26]:

$$
T R+\left(\frac{y}{2}\right) H_{2} \longrightarrow T R H_{y}+\Delta H
$$

referente à fase rica em terra-rara, onde $y$ depende da pressão de $\mathrm{H}_{2}$. Já para a fase magnética, tem-se:

$$
T R_{2} F e_{14} B+\left(\frac{x}{2}\right) H_{2} \longrightarrow T R_{2} F e_{14} B H_{x}+\Delta H
$$

onde $x$ depende da temperatura e pressão e $\Delta H$ indica que as reações são exotérmicas (cada reação produzindo a energia necessária para que a próxima reação ocorra). A estrutura cristalina tetragonal da fase magnética permanece inalterada com a formação do hidreto, apenas com um acréscimo nos parâmetros de rede. Os autores também apresentam as vantagens do processo HD, descritas a seguir [26]:

I. A liga é transformada rapidamente em um material friável, onde possíveis dificuldades associadas à dureza da liga são eliminadas;

II. A eliminação do hidrogênio durante o aquecimento na etapa de sinterização produz uma camada redutora e protetora contra a oxidação; 
Isnard e colaboradores estudaram a localização dos átomos de hidrogênio na célula cristalina do composto $\mathrm{Nd}_{2} \mathrm{Fe}_{14} \mathrm{~B}$ utilizando a técnica de difração de nêutrons em amostras em pó [27].

Os autores verificaram que a inserção de hidrogênio envolve a ocupação de 4 sítios intersticiais diferentes. Verificaram também que o preenchimento destes sítios no composto $\mathrm{Nd}_{2} \mathrm{Fe}_{14} \mathrm{~B}$ é semelhante aquele verificado para a série $\mathrm{Ce}_{2} \mathrm{Fe}_{14} \mathrm{BH}_{\mathrm{x}}$. A inserção de hidrogênio reduz a distância entre os átomos de neodímio e boro. Os autores também relacionaram o aumento da distância entre os átomos de ferro com a variação na temperatura de Curie $\left(T_{c}\right)$. A Fig.10 apresenta as posições intersticiais ocupadas pelos átomos de hidrogênio na célula cristalina do composto $\mathrm{Nd}_{2} \mathrm{Fe}_{14} \mathrm{~B}$ [27].

Figura 10: Sítios intersticiais ocupados pelo $\mathrm{H}_{2}$ na estrutura do composto $\mathrm{Nd}_{2} \mathrm{Fe}_{14} \mathrm{~B}$.
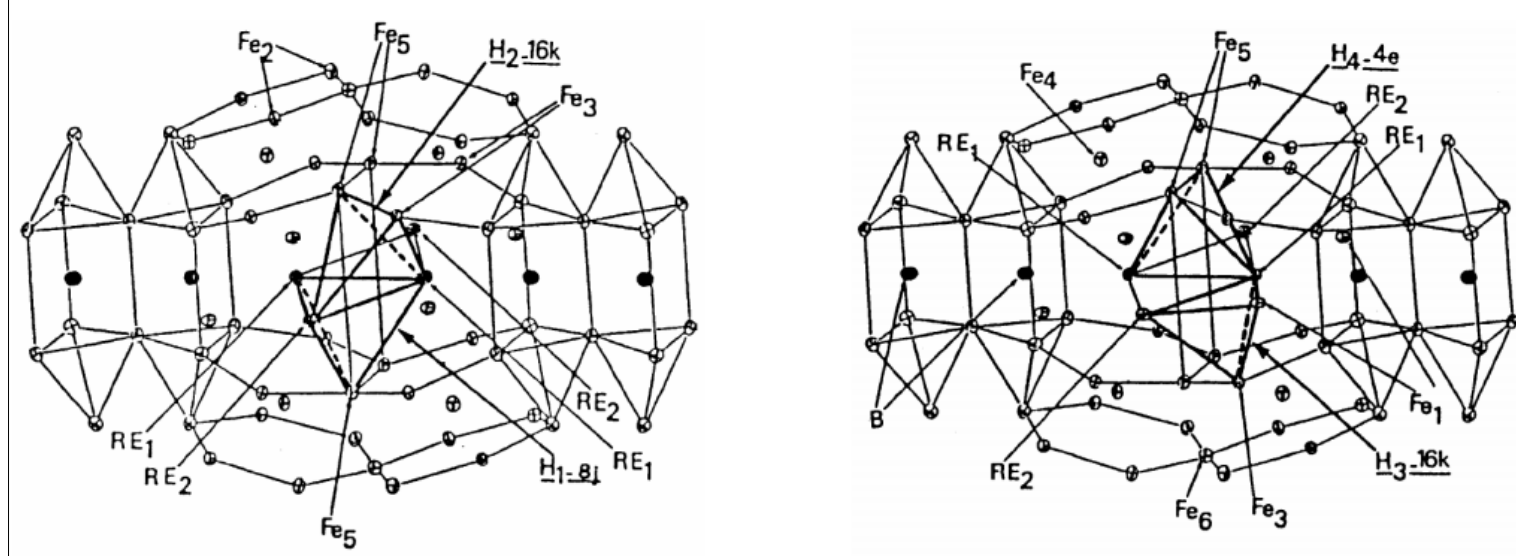

Fonte: [27].

\subsection{A Moagem de Alta Energia (MAE) nos ímãs permanentes de NdFeB}

O processo de moagem de alta energia (MAE) na produção de ímãs permanentes sinterizados de NdFeB é um tema pouco abordado e estudado na literatura, visto a quantidade reduzida de trabalhos científicos sobre o assunto. Muitos trabalhos utilizam a MAE como parte do processo de produção dos ímãs, porém o tema central de estudo é outro.

Nothnagel e colaboradores estudaram a influência de corpos moedores com diferentes diâmetros durante o processo de moagem por atrito na produção de ímãs permanentes de $\mathrm{Nd}_{16} \mathrm{Fe}_{78} \mathrm{~B}_{6} \mathrm{Al}_{0,4}$ [28]. 
Produziram ímãs com $B_{r}=1,23 \mathrm{~T},{ }_{i} \mathrm{H}_{\mathrm{C}}=1,24 \mathrm{~T}$ e $(\mathrm{BH})_{\mathrm{MÁx}}=283 \mathrm{KJ} / \mathrm{m}^{3} \mathrm{com}$ as esferas que possuíam o menor diâmetro utilizado $(d=3 \mathrm{~mm})$ [28].

Hosseini e Kianvash investigaram a influência da atmosfera de moagem nas propriedades magnéticas de ímãs de $\mathrm{Nd}_{12,8} \mathrm{Fe}_{79,8} \mathrm{~B}_{7,4}$. Os autores investigaram três tipos de meios de moagem de bolas: atmosfera de nitrogênio, meio de ciclohexano e atmosfera de nitrogênio em meio de ciclohexano. Após sinterizarem os ímãs à $1080^{\circ} \mathrm{C}$ por 1 hora, concluíram que as melhores propriedades magnéticas foram obtidas para o pó produzido sob atmosfera de $\mathrm{N}_{2}$ em meio de ciclohexano, devido ao melhor controle da oxidação dos pós durante o processo de moagem [29].

Faria e colaboradores avaliaram a influência do tempo de moagem convencional nas propriedades magnéticas de ímãs sinterizados de $\operatorname{Pr}_{16} \mathrm{Fe}_{76} \mathrm{~B}_{8} \mathrm{e}$ $\operatorname{Pr}_{17} \mathrm{Fe}_{79} \mathrm{~B}_{4}$. A moagem dos pós foi realizada sob meio de ciclohexano entre 9 e 36 horas. Concluíram que para as ligas $\operatorname{Pr}_{16} \mathrm{Fe}_{76} \mathrm{~B}_{8}$ e $\operatorname{Pr}_{17} \mathrm{Fe}_{79} \mathrm{~B}_{4}$ os melhores tempos de moagem foram $18\left(\mathrm{~B}_{\mathrm{r}}=1,19 \mathrm{~T} ;{ }_{\mathrm{i}} \mathrm{H}_{\mathrm{C}}=1,44 \mathrm{~T}\right.$ e $\left.(\mathrm{BH})_{\mathrm{MÁX}}=280 \mathrm{KJ} / \mathrm{m}^{3}\right)$ e 27 horas $\left(\mathrm{B}_{\mathrm{r}}=1,14 \mathrm{~T} ;{ }_{i} \mathrm{H}_{\mathrm{C}}=1,16 \mathrm{~T}\right.$ e $\left.(\mathrm{BH})_{\text {MÁx }}=217 \mathrm{KJ} / \mathrm{m}^{3}\right)$, respectivamente [30].

Harris e Kianvash investigaram o processo de moagem vibratória atmosfera de $\mathrm{H}_{2}$ como possível substituto da moagem de rolos na produção de ímãs sinterizados de $\mathrm{Nd}_{16} \mathrm{Fe}_{76} \mathrm{~B}_{8}$. Concluíram que a moagem vibratória sob atmosfera de $\mathrm{H}_{2}$ foi mais eficiente em produzir partículas mais finas em um tempo menor, além do controle de oxidação ser superior [31]. 


\section{MATERIAIS E MÉTODOS}

O presente trabalho foi realizado nas dependências do Laboratório de Materiais Magnéticos, localizado na Divisão de Caracterização de Materiais do Centro de Ciência e Tecnologia de Materiais (CCTM) desta instituição - IPEN. A caracterização magnética dos ímãs produzidos também foi realizada nas dependências do Laboratório de Materiais Magnéticos da Universidade Federal de Santa Catarina (MAGMA-UFSC).

\subsection{Matéria-prima}

A liga metálica utilizada no presente estudo foi adquirida da Less Common Metals. Esta liga foi produzida pelo processo de lingotamento em tiras (stripcasting).

Este processo de produção consiste na solidificação rápida da liga fundida, produzindo tiras. Um dos grandes benefícios deste processo de produção da liga é que, devido ao resfriamento rápido, existe a supressão da fase de $\mathrm{Fe}-\alpha$, que é comumente encontrada nas ligas magnéticas no estado bruto de fusão. Esta fase de Fe- $\alpha$ é prejudicial às propriedades magnéticas e requer um ciclo térmico de aproximadamente 20 horas para a eliminação completa desta fase [32]. A composição química da liga é apresentada na Tab.3.

Tabela 3: Composição química da liga strip-cast.

\begin{tabular}{cc}
\hline Composição química & $\begin{array}{c}\text { Porcentagem atômica } \\
(\%)\end{array}$ \\
\hline $\mathbf{N d} / \mathbf{P r}$ & 13,49 \\
$\mathbf{F e}$ & 77,72 \\
$\mathbf{B}$ & 6,00 \\
$\mathbf{A l}$ & 1,20 \\
$\mathbf{N b}$ & 0,28 \\
$\mathbf{C u}$ & 0,20 \\
$\mathbf{C o}$ & 1,10 \\
Total & 100,00 \\
\hline
\end{tabular}




\subsection{Processo de Produção dos Ímãs}

Os ímãs permanentes sinterizados foram produzidos via rota convencional de metalurgia do pó aliada ao processo de Decrepitação por Hidrogênio (HD). As etapas de produção dos ímãs estão detalhadas a seguir.

\subsubsection{Decrepitação por Hidrogênio (HD)}

Cerca de $15 \mathrm{~g}$ de liga metálica foram alocados em um cadinho $(\phi=15 \mathrm{~mm}-$ aço inoxidável $316 \mathrm{~L}$ ) e inserido em um vaso de hidrogenação.

Introduziu-se hidrogênio $\left(\mathrm{H}_{2}\right)$ com pressão de $0,2 \mathrm{MPa}$ (2,0bar), que foi absorvido pela liga, formando hidretos. Estes hidretos formados causam uma expansão do retículo cristalino no material, resultando na formação de trincas intra e intergranulares [24].

Com o início da reação de hidrogenação, é possível observar diminuição na pressão de hidrogênio introduzida inicialmente e aumento de temperatura no vaso de hidrogenação, indicando que o processo de formação dos hidretos metálicos é exotérmico.

Após o final deste processo o material torna-se friável, facilitando a obtenção de pós finos. A Fig.11 apresenta o aspecto da matéria-prima antes e após o processo de hidrogenação, respectivamente. 
Figura 11: Matéria-prima antes e após o processo de decrepitação por hidrogênio (HD), respectivamente.

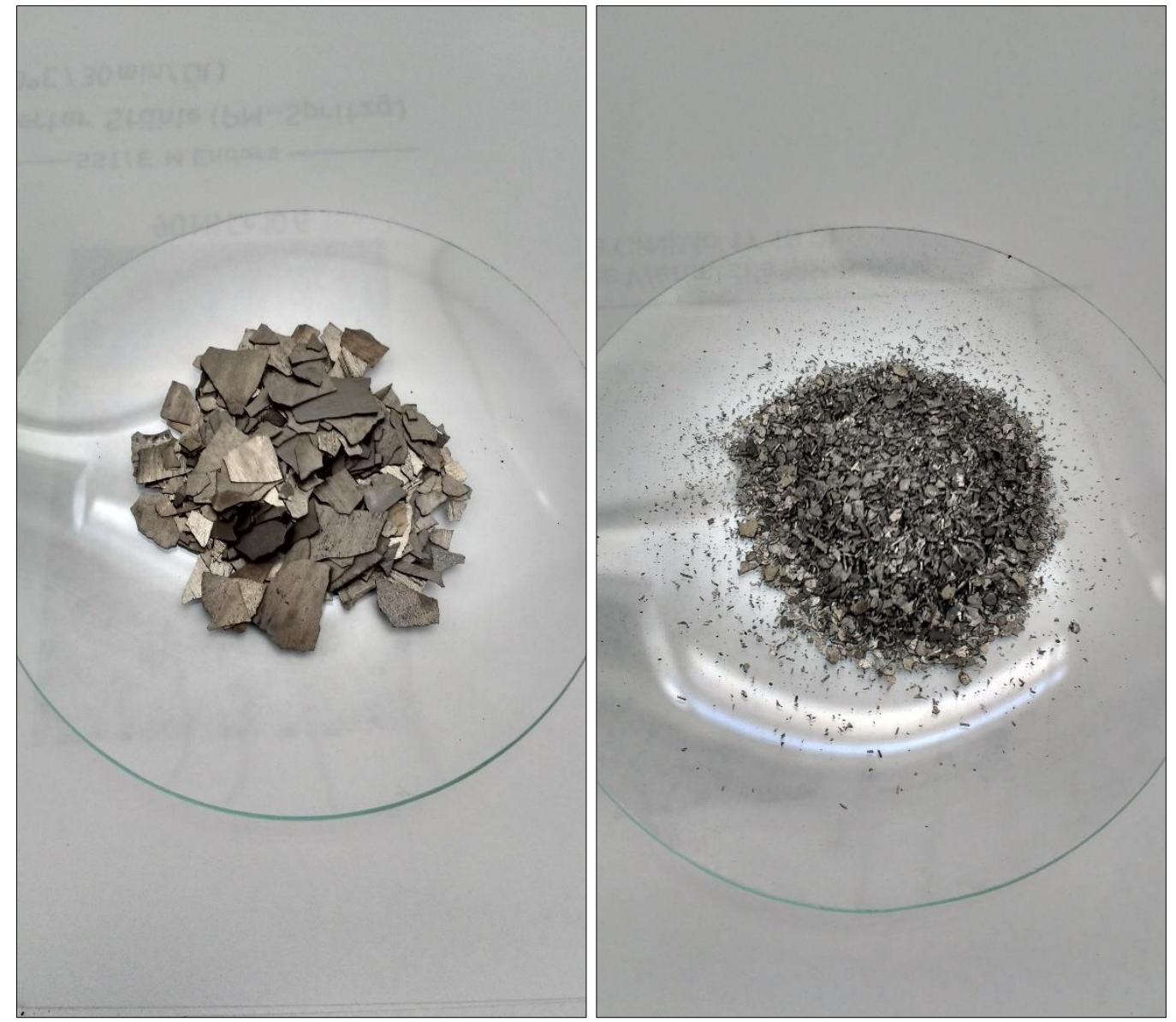

\subsubsection{Moagem Planetária de Alta Energia}

Nesta etapa, o material resultante do processo HD foi transferido para um vaso de moagem de aço inoxidável contendo esferas de moagem do mesmo material com diâmetro de $3 \mathrm{~mm}$. A proporção esferas:massa de amostra foi de 10:1.

O processo de moagem foi realizado em meio líquido com $20 \mathrm{ml}$ de ciclohexano, utilizado para evitar a aglomeração do material e oxidação do pó durante esta etapa.

Para avaliar a influência da moagem de alta energia na microestrutura e nas propriedades magnéticas dos ímãs produzidos, foi estudado um período de processamento definido entre 30 e 75 minutos, com intervalos regulares de 15 minutos, à uma velocidade constante de $200 \mathrm{rpm}$. O moinho de alta energia utilizado nesta etapa do trabalho foi o Fritsch Pulverisette P5. 


\subsubsection{Secagem e Transferência}

Ao término da moagem, um dispositivo de secagem foi acoplado ao pote de moagem, e esse sistema foi conectado a uma bomba de vácuo (Edwards modelo 5). Então, a secagem do pó foi realizada por cerca de 15 minutos.

Após a evaporação do ciclohexano, adaptou-se ao pote de moagem um dispositivo que possibilita a transferência do pó para um molde de borracha, sob atmosfera inerte $\left(\mathrm{N}_{2}\right)$ [33].

A Fig.12 apresenta o sistema de secagem e transferência do pó, desenvolvido por Takiishi e colaboradores.

Figura 12: Sistema de secagem e transferência do pó.

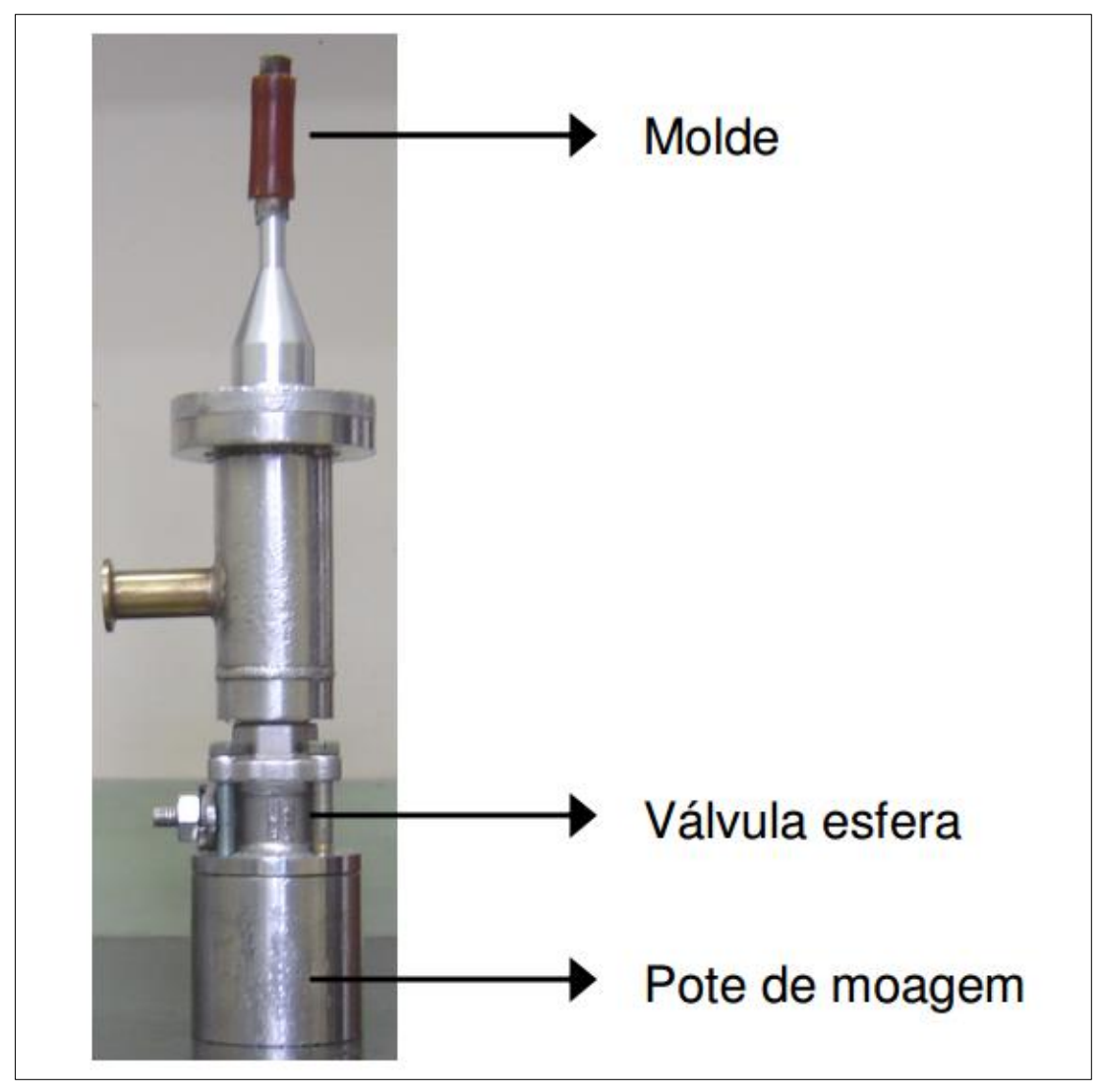

Fonte: [41] 


\subsubsection{Alinhamento de Partículas e Compactação}

Após a transferência do pó para o molde, o material foi submetido a um campo magnético de $6 \mathrm{~T}$ por meio de um magnetizador (LDJ modelo 450-20C) para o alinhamento das partículas do pó com o campo aplicado, conforme apresentado na Fig.13.

Figura 13: Magnetizador modelo LDJ 450-20C [ELIO].

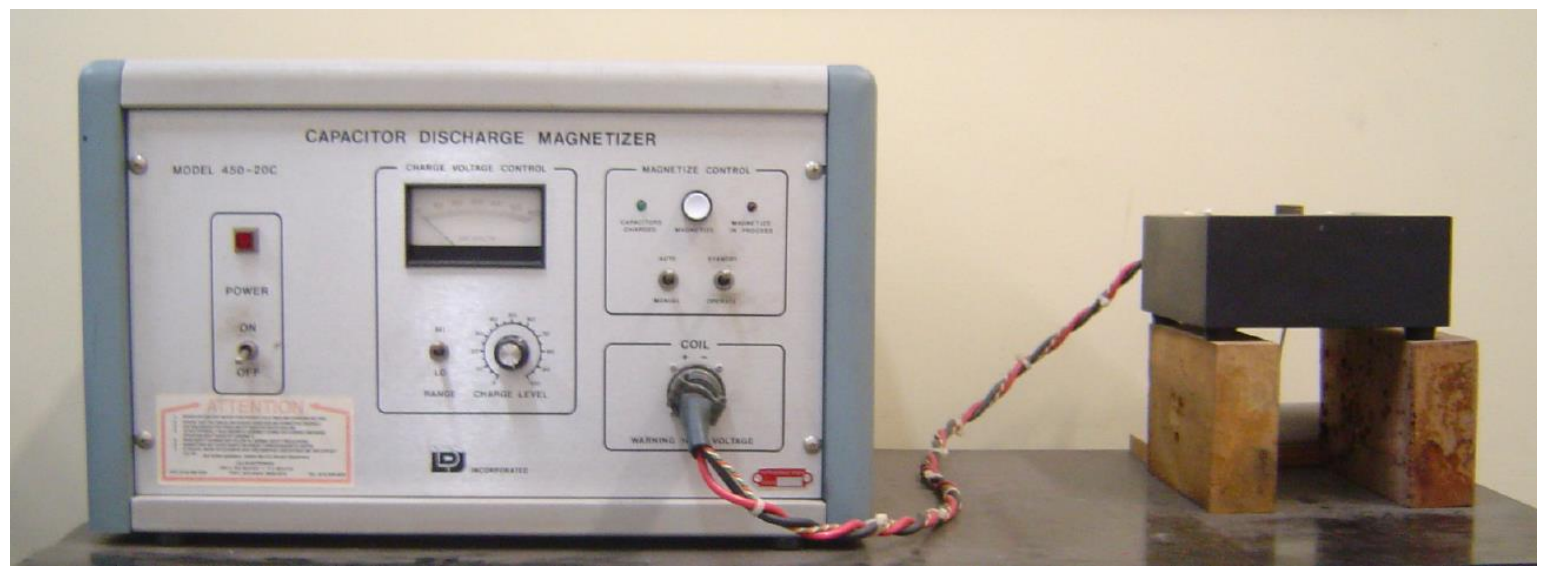

Fonte: [41].

O alinhamento orienta os eixos de fácil magnetização das partículas de forma paralela ao campo, induzindo uma direção preferencial de alinhamento (textura cristalográfica), produzindo assim um material anisotrópico. Este alinhamento promove um aumento das propriedades magnéticas dos ímãs.

Em seguida, o pó foi compactado isostaticamente a uma pressão de 200MPa.

\subsubsection{Sinterização}

O compactado verde foi alocado em um cadinho de aço inoxidável e inserido em uma retorta do mesmo material, conectada a um sistema de vácuo constituído por uma bomba mecânica acoplada a uma bomba difusora (Edwards - modelo SB63). Todo o processo de sinterização ocorre sob vácuo de 0,01Pa.

O processo de sinterização é realizado em rampa contínua até a temperatura de sinterização, à uma taxa de aquecimento de $5^{\circ} \mathrm{C} /$ minuto $(5 \mathrm{~K} / \mathrm{min})$.

Durante a etapa de aquecimento, ocorre a desidrogenação do material. Em cerca de $200^{\circ} \mathrm{C}$ (473K) ocorre o primeiro estágio de desidrogenação, onde o $\mathrm{H}_{2}$ é liberado da fase matriz $\left(\mathrm{Nd}_{2} \mathrm{Fe}_{14} \mathrm{~B}\right)$. Por volta de $650^{\circ} \mathrm{C}(923 \mathrm{~K})$ ocorre o segundo 
estágio de desidrogenação, onde $\mathrm{o}^{\mathrm{H}_{2}}$ é liberado da fase rica em neodímo, presente nos contornos de grão.

Por fim, os compactos verdes foram sinterizados à uma temperatura de $1100^{\circ} \mathrm{C}$ (1373K) por uma hora, seguidos de resfriamento ao ar fora do forno.

\subsection{Caracterização dos Ímãs}

\subsubsection{Caracterização Magnética}

Os ímãs produzidos foram caracterizados em um permêametro LDJ modelo BH-5000 e em um histeresígrafo Brockhaus modelo Hystograph HG 200, conforme apresentado na Fig.14, fornecendo os valores de remanência $\left(B_{r}\right)$ e coercividade intrínseca $\left(\mathrm{i}_{\mathrm{c}}\right)$, por meio da curva de desmagnetização.

A partir de cálculos baseados na curva de desmagnetização, outras propriedades magnéticas de grande importância são obtidas. São elas: coercividade indutiva $\left({ }_{b} H_{c}\right)$, produto de energia máximo $\left((\mathrm{BH})_{M A ́ x}\right)$ e fator de quadratura (SF).

Figura 14: Permeâmetro BH 5000.

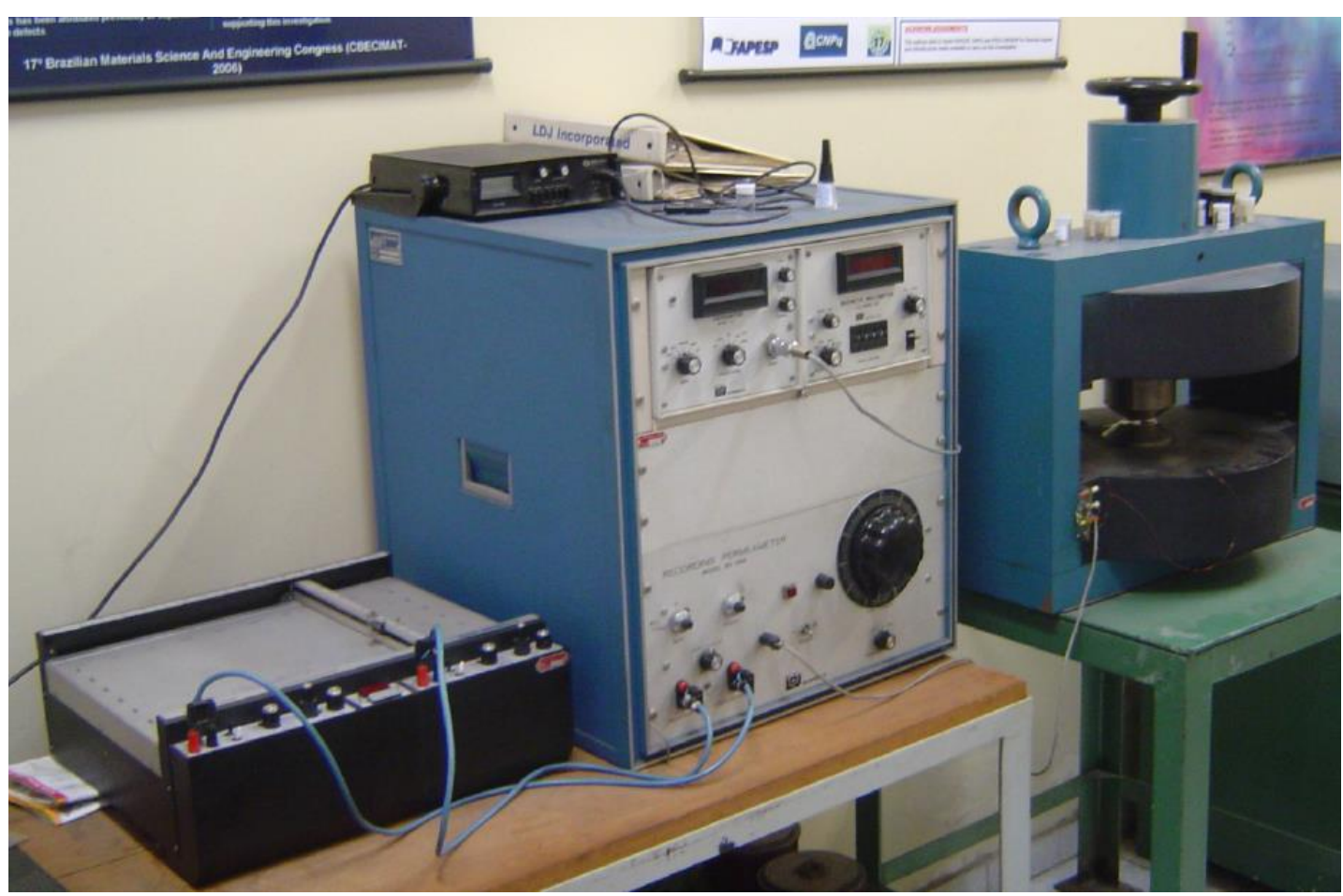

Fonte: [41]. 


\subsubsection{Densidade}

Utilizou-se o método de Arquimedes para determinar a densidade de cada ímã produzido. Por este método, foram medidas as massas da amostra seca $\left(m_{\mathrm{s}}\right)$, úmida $\left(\mathrm{m}_{\mathrm{u}}\right)$ e imersa $\left(\mathrm{m}_{\mathrm{i}}\right)$ em água deionizada, utilizando uma balança Shimadzu modelo AX200. A densidade é calculada pela equação 16:

$$
\rho=\left(\frac{m s}{m u-m i}\right) \rho_{\text {Água }}
$$

\subsubsection{Caracterização Metalográfica}

Para a caracterização da matéria-prima e dos ímãs produzidos, técnicas convencionais de embutimento a frio em resina, lixamento e polimento foram empregadas. Para avaliar a estrutura de grãos dos ímãs, uma solução 0,2 mol de ácido nítrico foi utilizada para realizar o ataque químico superficial das amostras.

As imagens foram obtidas por um microscópio eletrônico de varredura (MEV), Hitachi modelo TM-3000 com tensão de aceleração de $15 \mathrm{keV}$.

A partir das micrografias das amostras superficialmente atacadas pelo reagente, o analisador de imagens ImageJ foi utilizado para calcular o diâmetro médio de grãos. Para cada amostra, foram analisados, no mínimo, 600 grãos.

Foram determinados os valores médios de diâmetro de grão e seus respectivos desvios padrões aproximando os dados obtidos à uma distribuição logarítimica normal, conforme descrito por Ramesh e colaboradores [34].

\subsubsection{Difração de Raios-X}

No presente trabalho, a técnica de difração de raios-X foi utilizada para quantificar o grau de alinhamento cristalográfico dos ímãs produzidos. Nesta etapa, utilizou-se um difratômetro Bruker modelo D8 Advance $3 k W$. Os parâmetros utilizados nesta análise são:

- Radiação: cobre-K $\alpha, \lambda=1,5406 \AA$;

- Faixa angular: $20^{\circ} \leq 2 \theta \leq 70^{\circ}, 4$ segundos por passo de $0,04^{\circ}$. 
O método consiste na relação entre a razão da intensidade de uma reflexão (hkl) de um ímã anisotrópico e a intensidade apresentada por um ímã isotrópico versus o ângulo formado entre um certo plano (hkl) e um plano (00l).

Os dados foram ajustados para uma distribuição gaussiana, e a integração da curva, utilizando a equação 17, proposta por Herbst e Tracy [35]:

$$
<\cos \theta>=\frac{\int_{0}^{\pi / 2} f(\alpha) \operatorname{sen}(\alpha) \cos (\alpha) d \alpha}{\int_{0}^{\pi / 2} f(\alpha) \operatorname{sen}(\alpha) d a}
$$

onde $\alpha$ é o ângulo formando entre o eixo $c$ da estrutura cristalina da fase $\mathrm{Nd}_{2} \mathrm{Fe}_{14} \mathrm{~B}$ e a direção do campo magnético empregado na orientação amostra.

A integração da função gaussiana descrita acima fornece um valor que simboliza o grau de alinhamento $(<\cos \theta>)$, onde $<\cos \theta>=0,5$ indica alinhamento aleatório e $<\cos \theta>=1$ indica totalmente alinhado [36]. 


\section{RESULTADOS E DISCUSSÃO}

\subsection{Caracterização Magnética}

As curvas de desmagnetização dos ímãs produzidos são apresentadas na Fig.15. Para o melhor entendimento das curvas de desmagnetização, as propriedades magnéticas obtidas estão sumarizadas na Tab.3.

Figura 15: Curvas de desmagnetização dos ímãs sinterizados produzidos.

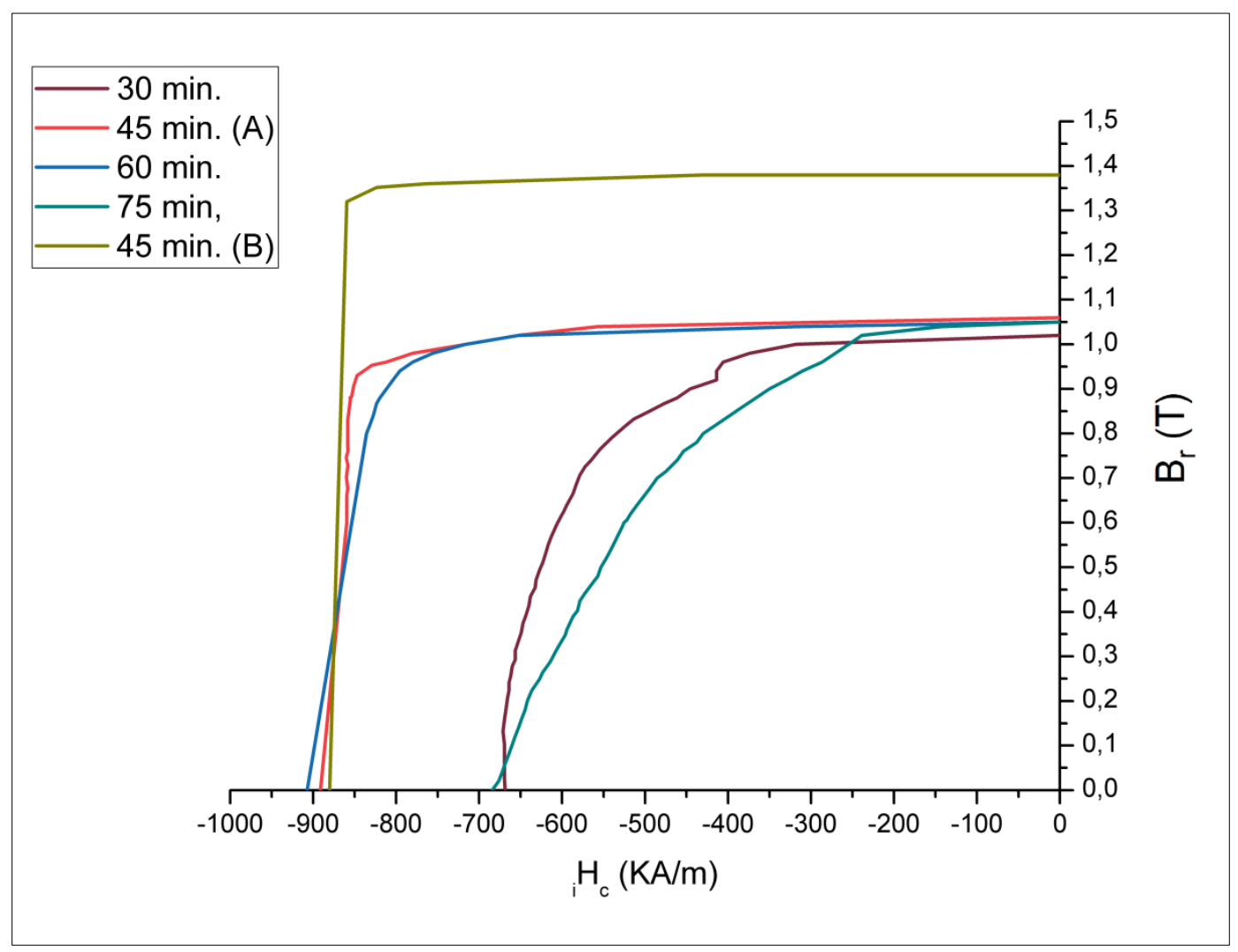

Tabela 4: Propriedades magnéticas dos ímãs produzidos.

$\begin{array}{llllll}\text { Amostra } & \mathrm{Br}(\mathrm{T}) & { }_{\mathrm{i}} \mathrm{H}_{\mathrm{c}} & { }_{\mathrm{b}} \mathrm{H}_{\mathrm{c}} & (\mathrm{BH})_{\text {máx }} & \mathrm{SF}\end{array}$




\begin{tabular}{cccccc}
\hline & & KA.m $\left.^{-1}\right)$ & (KA.m $\left.^{-1}\right)$ & (KJ.m $\left.^{-3}\right)$ & (razão) \\
\hline $\begin{array}{c}\mathbf{3 0} \text { minutos de } \\
\text { moagem }\end{array}$ & 1,02 & 652,5 & 572,9 & 143 & 0,66 \\
$\begin{array}{c}\mathbf{4 5} \text { minutos de } \\
\text { moagem (A) }\end{array}$ & 1,06 & 891,3 & 779,8 & 211 & 0,92 \\
$\mathbf{4 5}$ minutos de \\
moagem (B)
\end{tabular}

As propriedades magnéticas apresentam uma evolução conforme o tempo de moagem aumenta, atingindo um ponto máximo. Após esse máximo, as propriedades magnéticas começam a decrescer novamente. Fica evidente que existe um tempo adequado de processamento da liga, que é de 45 minutos de moagem.

Amostras produzidas com o mesmo tempo de moagem (45 minutos de processamento) apresentaram propriedades magnéticas muito distintas. Enquanto amostra 45-A apresentou uma remanência de 1,06 T, a amostra 45-B apresentou uma remanência 30\% superior $(\mathrm{Br}=1,38 \mathrm{~T})$. O ganho de propriedades não se limitou apenas à remanência, porém estendeu-se à todas outras propriedades, com excessão da coercividade intrínseca.

A amostra 45-B apresentou uma coercividade indutiva, produto de energia máximo e fator de quadratura 7, 56 e 2\% superiores, respectivamente.

Esta superioridade de propriedades magnéticas que a amostra 45-B apresentou em relação a amostra 45-A pode ter origem em muitos fatores. Um deles é a oxidação do pó durante o processo de moagem, que para amostra 45-B pode ter não ocorrido. Um fator que pode ter colaborado para o ganho de remanência é o grau de alinhamento. Como foi apresentado na equação 11 , a remanência depende do grau de alinhamento da amostra $(<\cos \theta>)$, da densidade relativa $(P)$, da fração volumétrica de fase magnética (f) e da magnetização de saturação da fase $\mathrm{Nd}_{2} \mathrm{Fe}_{14} \mathrm{~B}\left(\mathrm{I}_{\mathrm{s}}\right)$. A partir do grau de alinhamento do ímã, pode-se 
estimar a remanência $(\mathrm{Br})$, bem como a fração volumétrica de fase magnética (f) [18-22,45]. Esta discussão será aprofundada no tópico 5.4.

As amostras produzidas com de 30 e 75 minutos de moagem apresentaram uma redução de propriedades magnéticas quando comparadas às amostras produzidas com 45 minutos de moagem. Observa-se o surgimento de um "joelho" na curva de desmagnetização destas amostras. Este defeito na curva indica que defeitos microestruturais estão presentes no material, como por exemplo, uma distribuição ampla de diâmetros de grão e a presença de grãos anômalos.

No caso dos ímãs produzidos com 30 minutos de moagem, este "joelho" pode ter sua origem na heterogeneidade do tamanho de partícula devido ao tempo insuficiente de moagem, produzindo uma distribuição de grãos muito ampla [37-40].

No caso dos imãs produzidos com 75 minutos de moagem, a redução das propriedades magnéticas tem sua origem também em defeitos microestruturais. Tempos muito longos de moagem promovem uma destruição da superfície do grão. Outro fator é a própria granulometria no pó produzido, que não é adequada à temperatura de sinterização, favorecendo o fenômeno de crescimento anormal de grãos, produzindo também uma distribuição muito ampla de diâmetros de grãos. [37-40].

Outra propriedade muito importante extraída da curva de desmagnetização é o fator de quadratura (SF). Este fator é um indicativo da qualidade de um ímã. Fisicamente, este representa a quantidade de grãos magnéticos que revertem sua polarização sob um determinado valor de campo externo. Em um ímã ideal, este fator assumiria valor unitário e apresentaria uma curva perfeitamente quadrada, indicando que todos os seus grãos magnéticos reverteram sua polarização sob o mesmo valor de campo desmagnetizante [41]

Esta propriedade magnética está diretamente relacionada à microestrutura, podendo sofrer alterações de acordo com alguns fatores como, por exemplo, diâmetro médio e distribuição de tamanhos de grão, ficando evidente no perfil da curva de desmagnetização [41].

Os maiores fatores de quadratura foram obtidos para os ímãs produzidos com 45 minutos de moagem (amostras 45-A e 45-B, SF = 0,92 e 0,95, respectivamente), sendo $115 \%$ superior ao fator do imã produzido com 75 
minutos de moagem $(S F=0,43)$. Este valor elevado de fator de quadratura indica que defeitos microestruturais foram reduzidos nesta condição de processamento, sugerindo uma homogeneidade microestrutural superior às demais condições exploradas [41]. Esta discussão será aprofundada no tópico 5.3.

\subsection{Densidade}

As densidades obtidas dos ímãs sinterizados estão listadas na Tab.4.

Tabela 5: Densidade hidrostática dos ímãs sinterizados produzidos.

\begin{tabular}{cc}
\hline Tempo de moagem (min.) & Densidade $\left(\mathbf{g} / \mathbf{c m}^{3}\right)$ \\
\hline 30 & 7,27 \\
$45-A$ & 7,40 \\
$45-B$ & 7,42 \\
60 & 7,41 \\
75 & 7,40 \\
\hline
\end{tabular}

A densidade de um ímã é uma medida de grande importância, pois é um indicativo da qualidade da sinterização. Além disso, a remanência está intimamente ligada à densidade e em geral costuma apresentar altos valores para ímãs com densidades mais próximas da densidade teórica $\left(7,6 \mathrm{~g} / \mathrm{cm}^{3}\right)$. As amostras produzidas apresentaram densidades semelhantes, com exceção da amostra produzida com 30 minutos de moagem. Isto pode ter ocorrido devido ao tamanho de partícula que não está adequado à temperatura de sinterização. Intervalos insuficientes de moagem podem não reduzir o tamanho de partícula ideal para a sinterização [37-40].

\subsection{Microestrutura}

As Figs.16-20 apresentam as micrografias obtidas por MEV dos ímãs produzidos a partir dos diferentes tempos de moagem. 
Figura 16: Microscopia eletrônica de varredura (elétrons retroespalhados) do ímã produzido com 30 minutos de moagem.

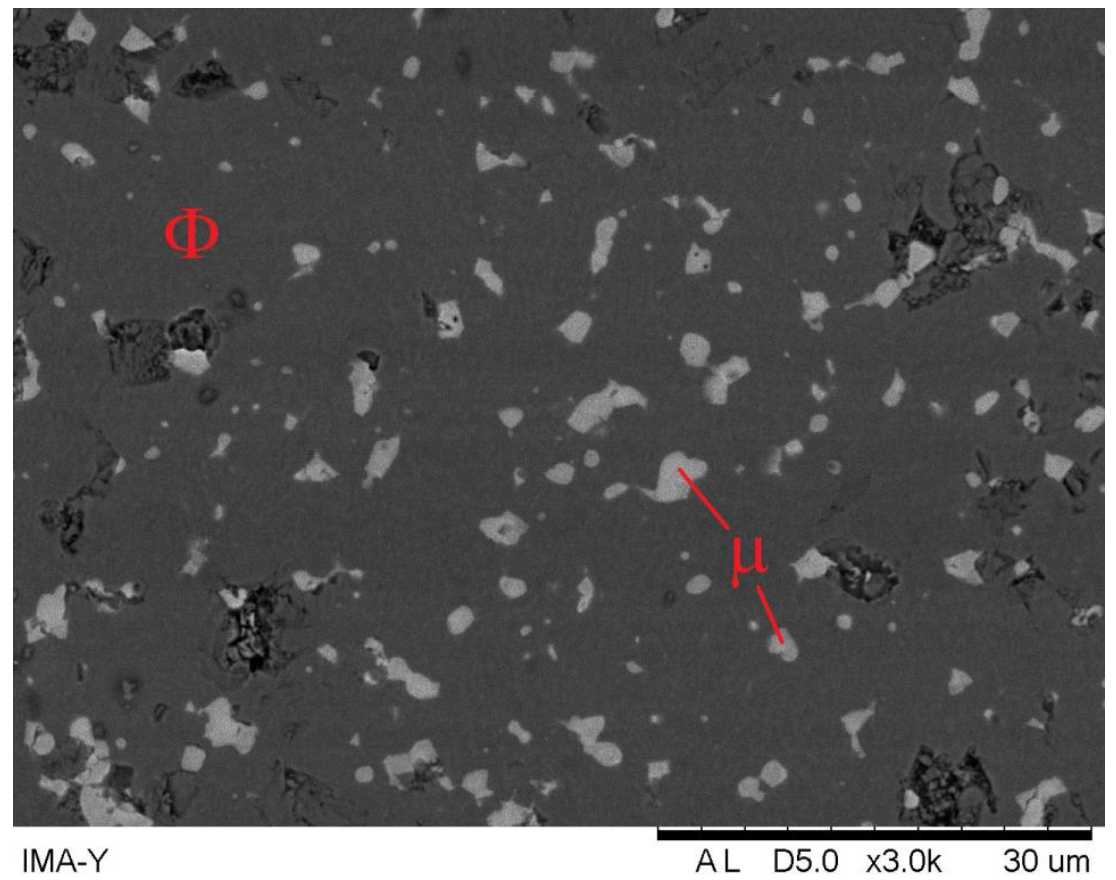

Figura 17: Microscopia eletrônica de varredura (elétrons retroespalhados) do ímã produzido com 45 minutos (45-A) de moagem.

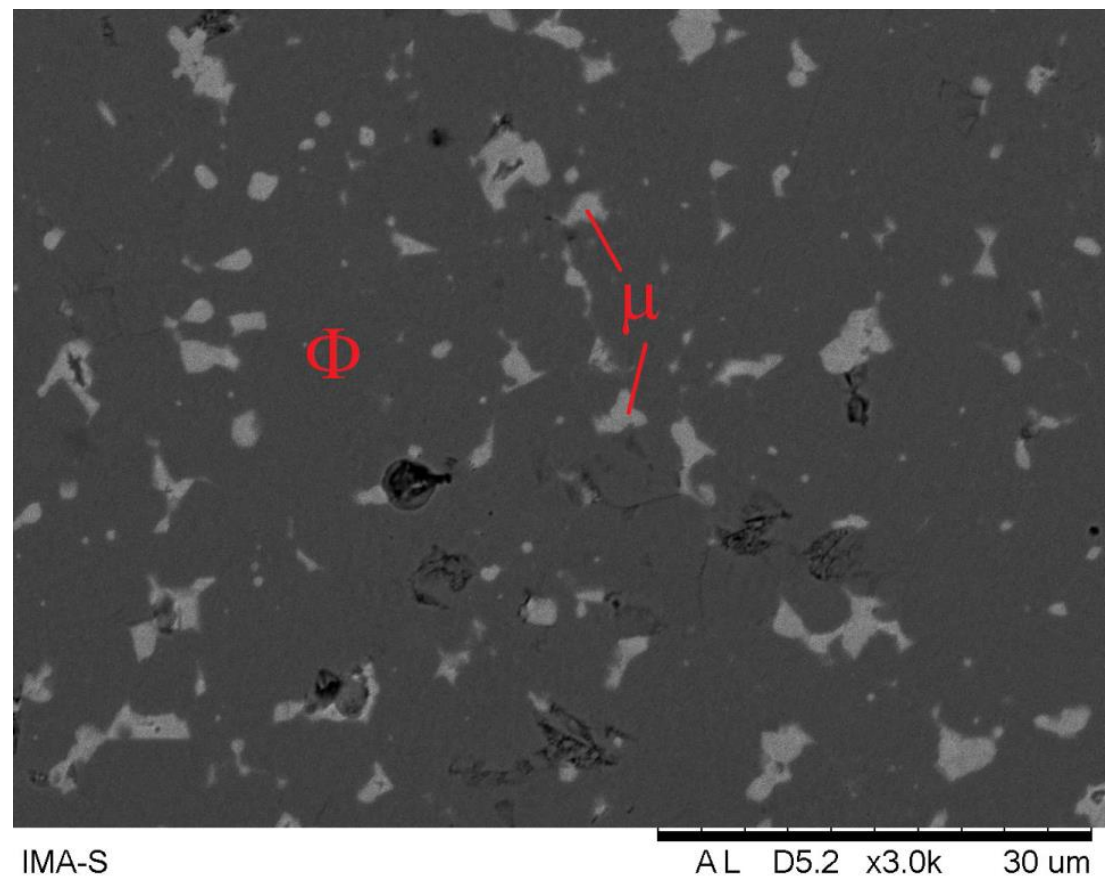


Figura 18: Microscopia eletrônica de varredura (elétrons retroespalhados) do ímã produzido com 45 minutos (45-B) de moagem.

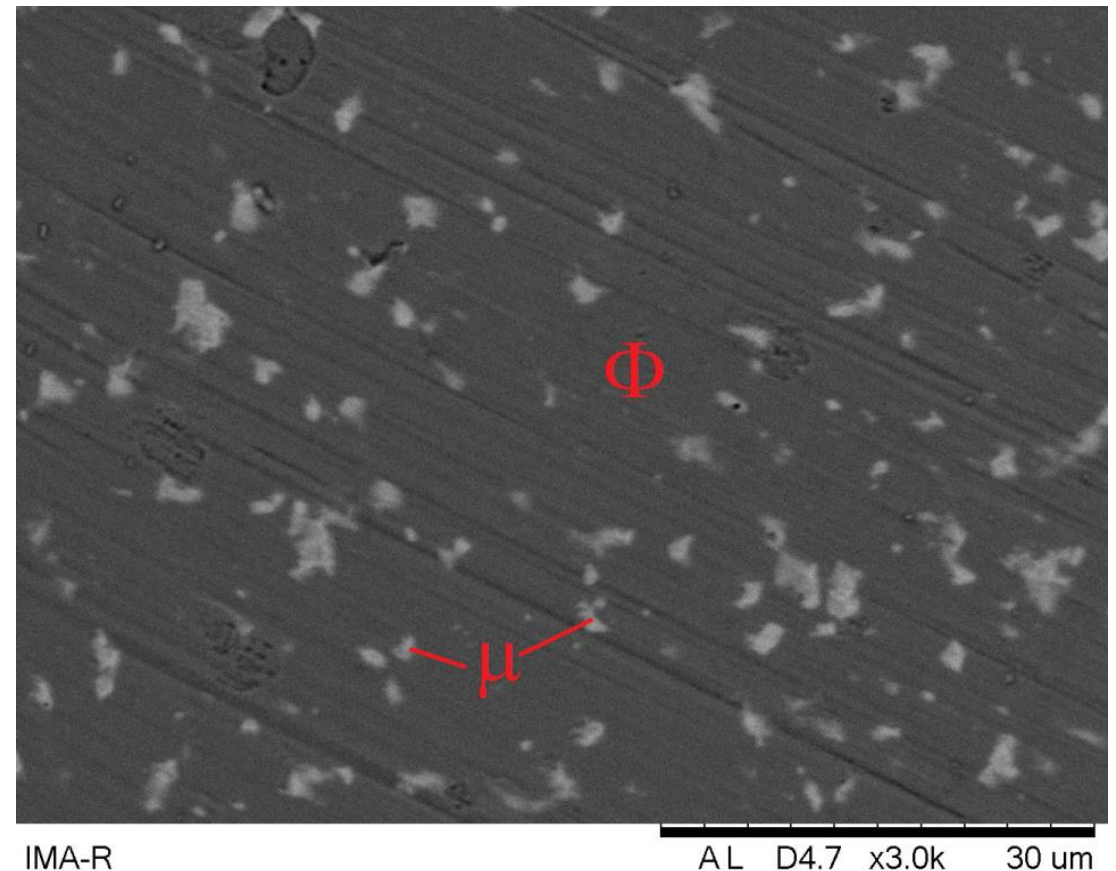

Figura 19: Microscopia eletrônica de varredura (elétrons retroespalhados) do ímã produzido com 60 minutos de moagem.

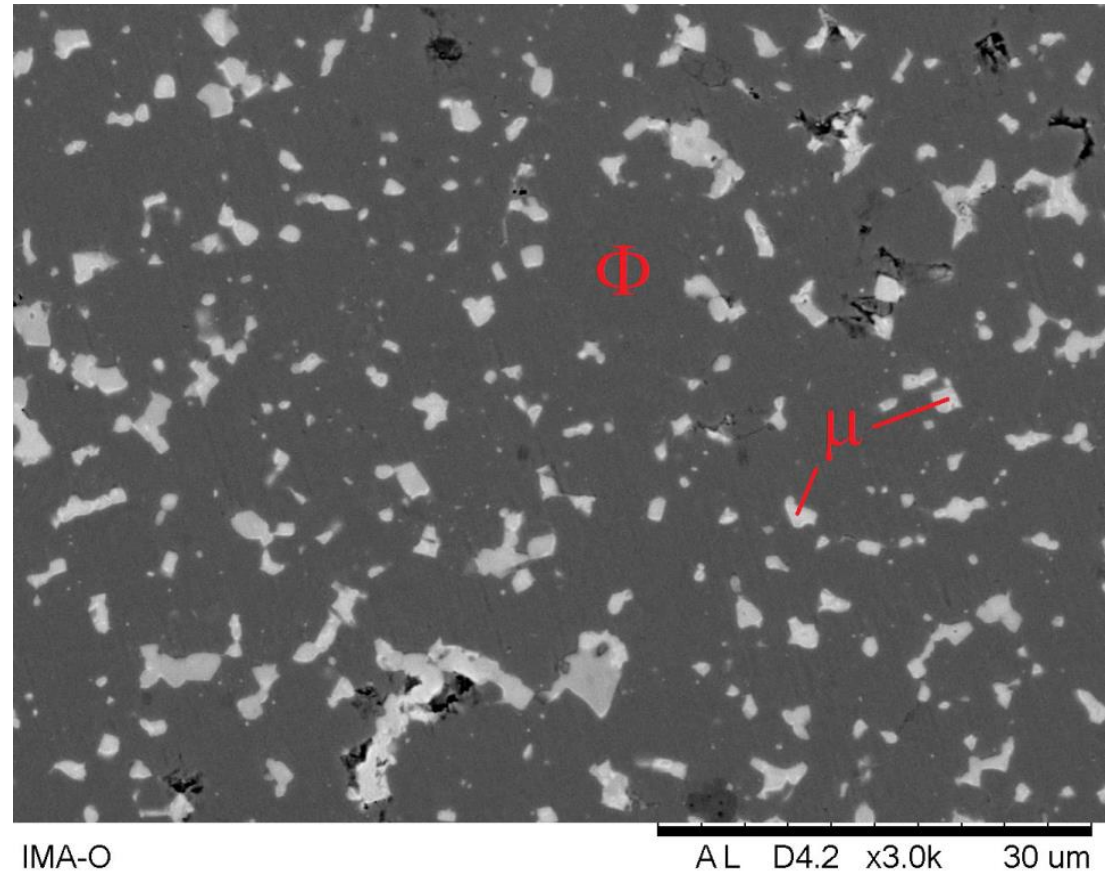


Figura 20: Microscopia eletrônica de varredura (elétrons retroespalhados) do ímã produzido com 75 minutos de moagem.

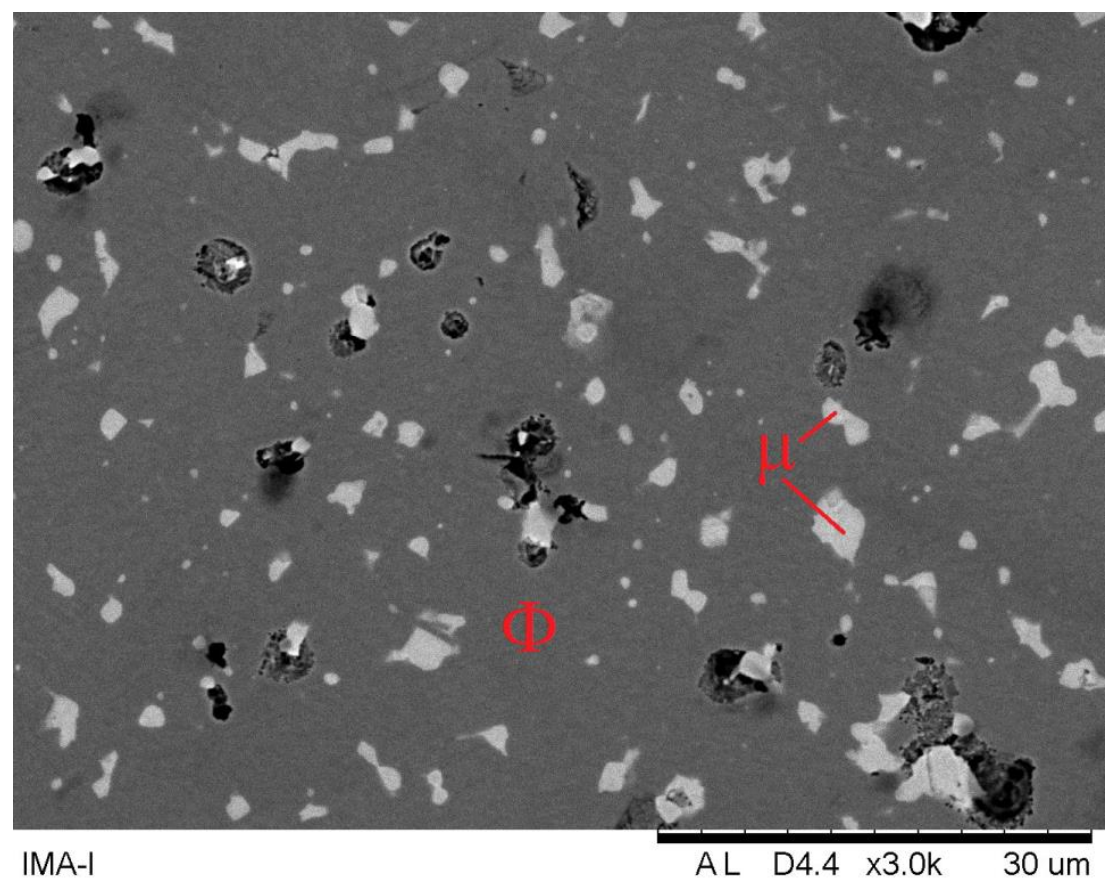

As micrografias acima apresentam a microestrutura típica de ímãs de TR-Fe$B$, com suas duas principais fases: a fase matriz $\left(\mathrm{Nd}_{2} \mathrm{Fe}_{14} \mathrm{~B}-\Phi\right)$ e a fase rica em $\mathrm{Nd}\left(\mathrm{Nd}_{2}(\mathrm{FeCo})-\mu\right)$ [42-44]. Não foram observadas mudanças microestruturais com a variação do tempo de moagem.

As Figs.21-25 apresentam as microestruturas de grãos dos ímãs produzidos. Estas amostras são as mesmas apresentadas na Figs.15-20, porém foram atacadas superficialmente com uma solução de $\mathrm{HNO}_{3} 0,2 \mathrm{~mol}$, com a finalidade de revelar tal estrutura. 
Figura 21: Microscopia eletrônica de varredura (elétrons retroespalhados) do ímã produzido com 30 minutos de moagem. Ataque superficial: solução 0,2 mol de $\mathrm{HNO}_{3}$.

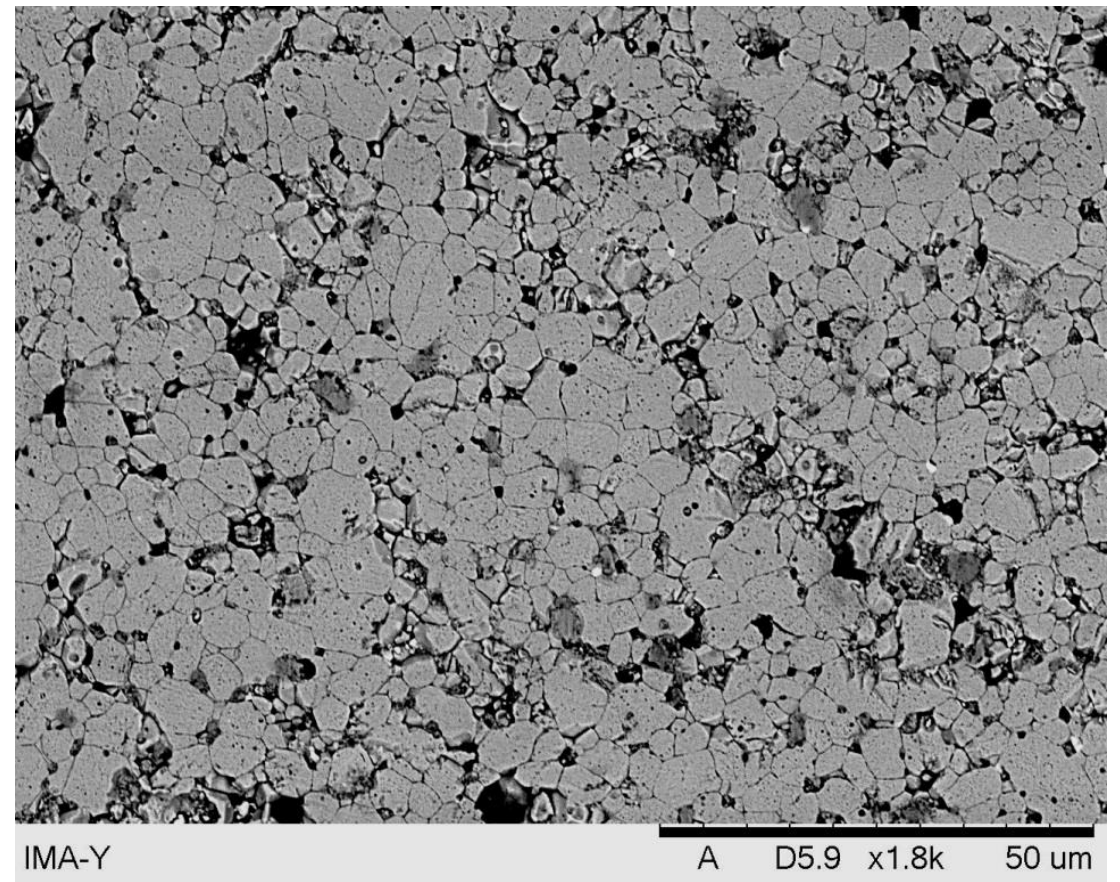

Figura 22: Microscopia eletrônica de varredura (elétrons retroespalhados) do ímã produzido com 45 minutos de moagem (45-A). Ataque superficial: solução 0,2 mol de $\mathrm{HNO}_{3}$.

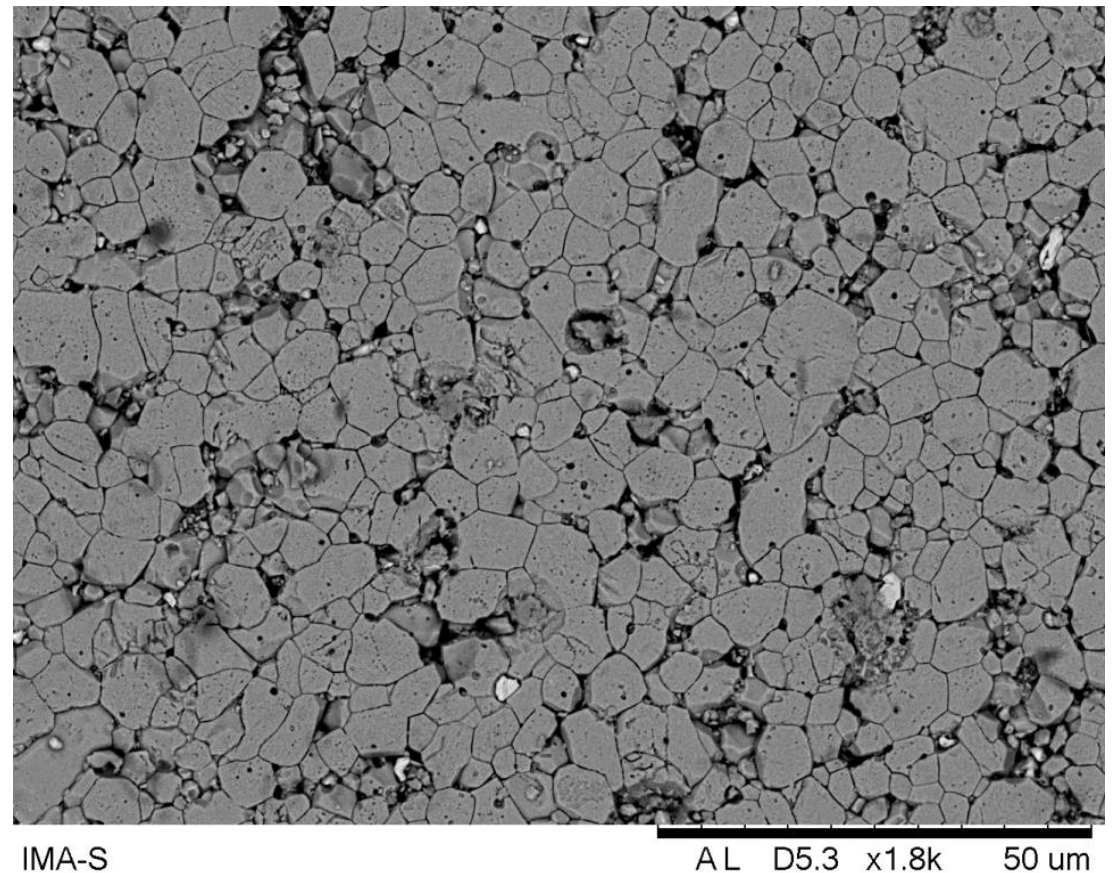


Figura 23: Microscopia eletrônica de varredura (elétrons retroespalhados) do ímã produzido com 45 minutos de moagem (45-B). Ataque superficial: solução 0,2 mol de $\mathrm{HNO}_{3}$.

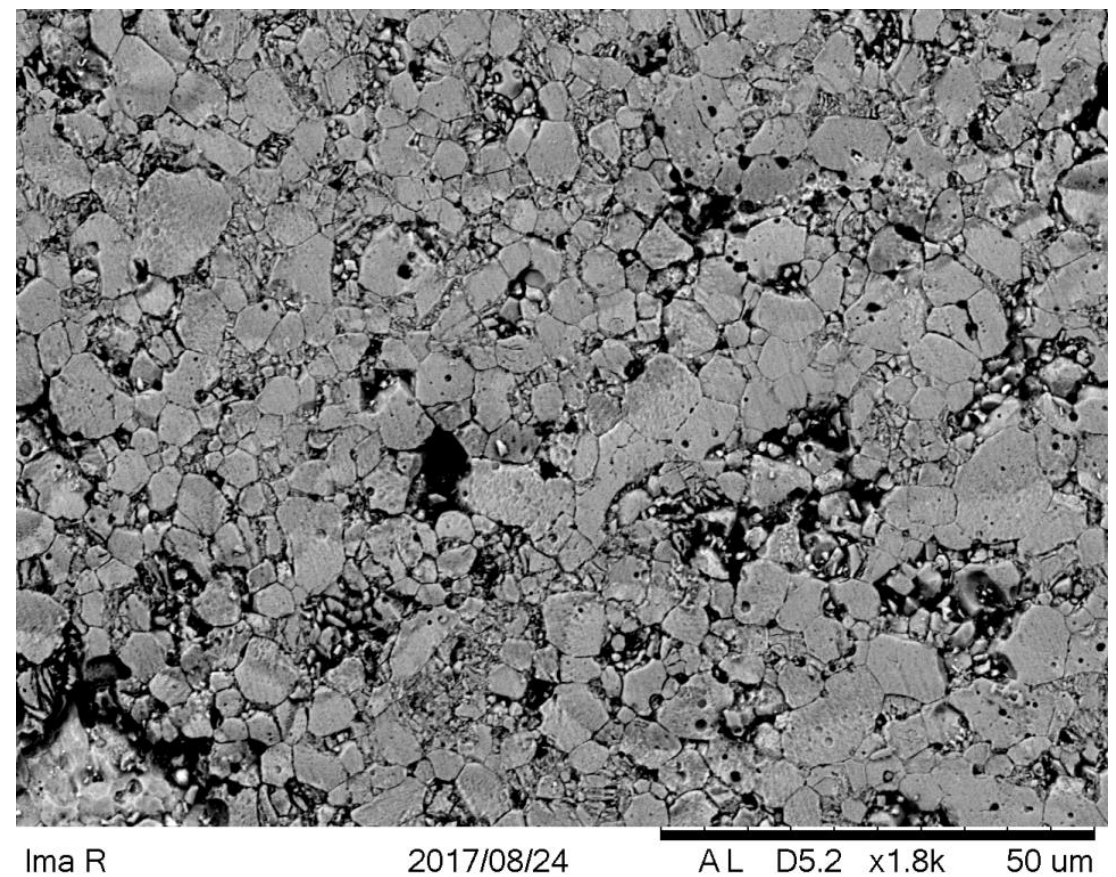

Figura 24: Microscopia eletrônica de varredura (elétrons retroespalhados) do ímã produzido com 60 minutos de moagem. Ataque superficial: solução 0,2 mol de $\mathrm{HNO}_{3}$.

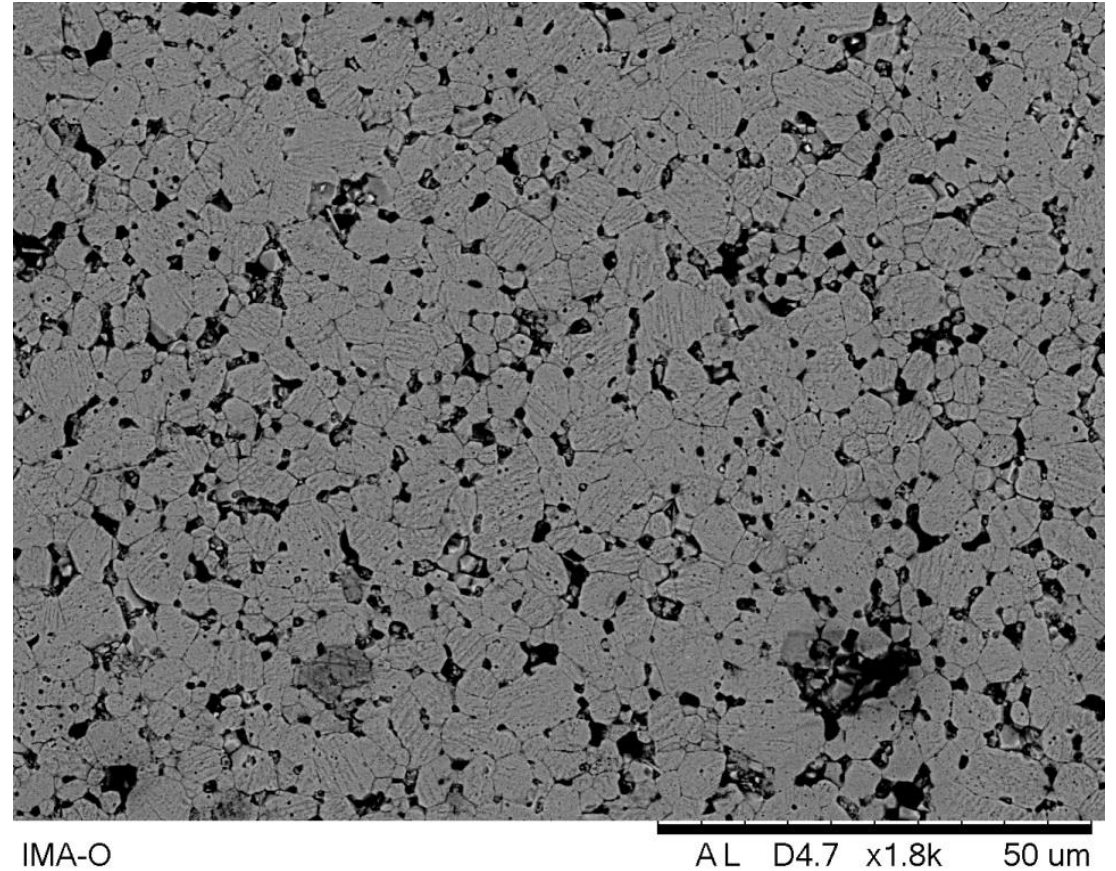


Figura 25: Microscopia eletrônica de varredura (elétrons retroespalhados) do ímã produzido com 75 minutos de moagem. Ataque superficial: solução 0,2 mol de $\mathrm{HNO}_{3}$.

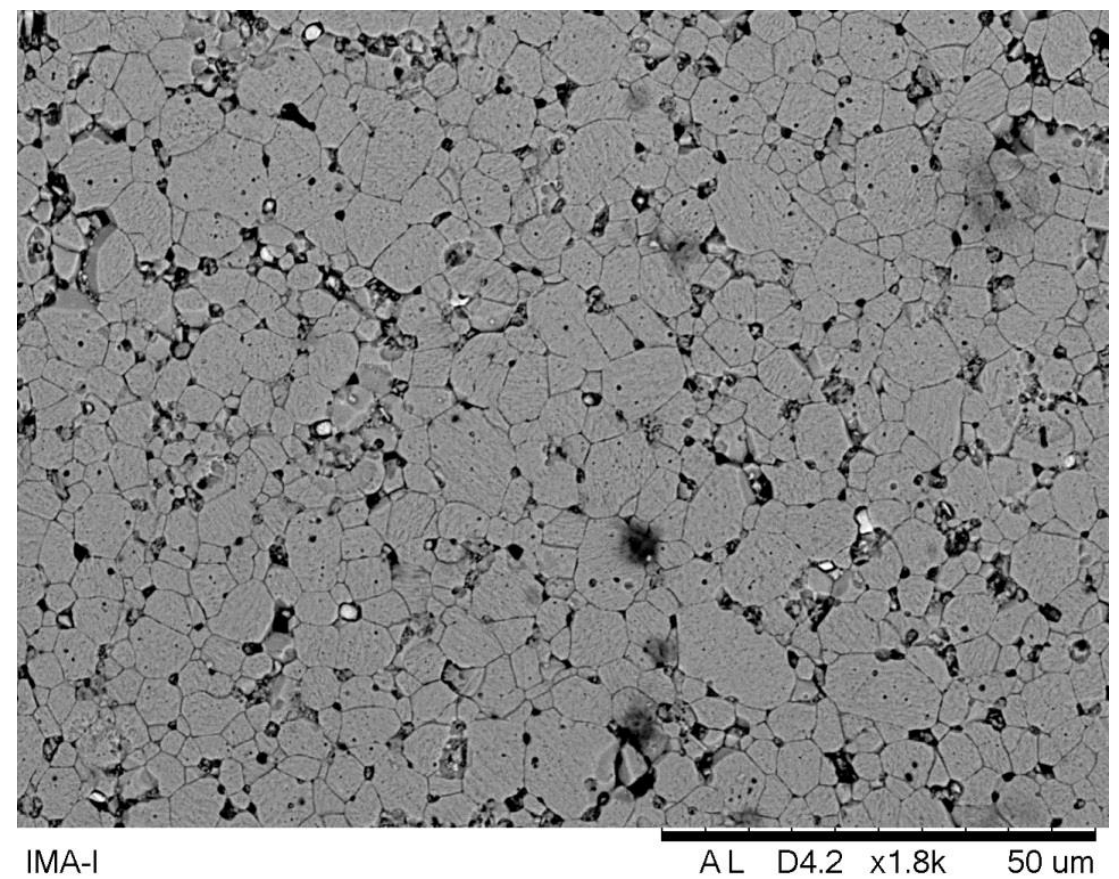

Observa-se que a microestrutura de grão é semelhante para cada amostra.

Utilizando o analisador de imagens ImageJ (versão 1.50i) foram realizadas análises de tamanho médio de grão e sua distribuição com base nas imagens obtidas. Foram analisados 600 grãos de cada amostra nesta análise. Como descrito anteriormente no tópico 4.3, a distribuição de diâmetro médio de grão de cada amostra foi aproximada para uma distribuição logarítmica de normal, como proposto por Ramesh [34].

A Figs.26-30 apresentam as curvas de distribuição obtidas para cada amostra. 
Figura 26: Distribuição dos tamanhos de grãos do ímã produzido com 30 minutos de moagem.

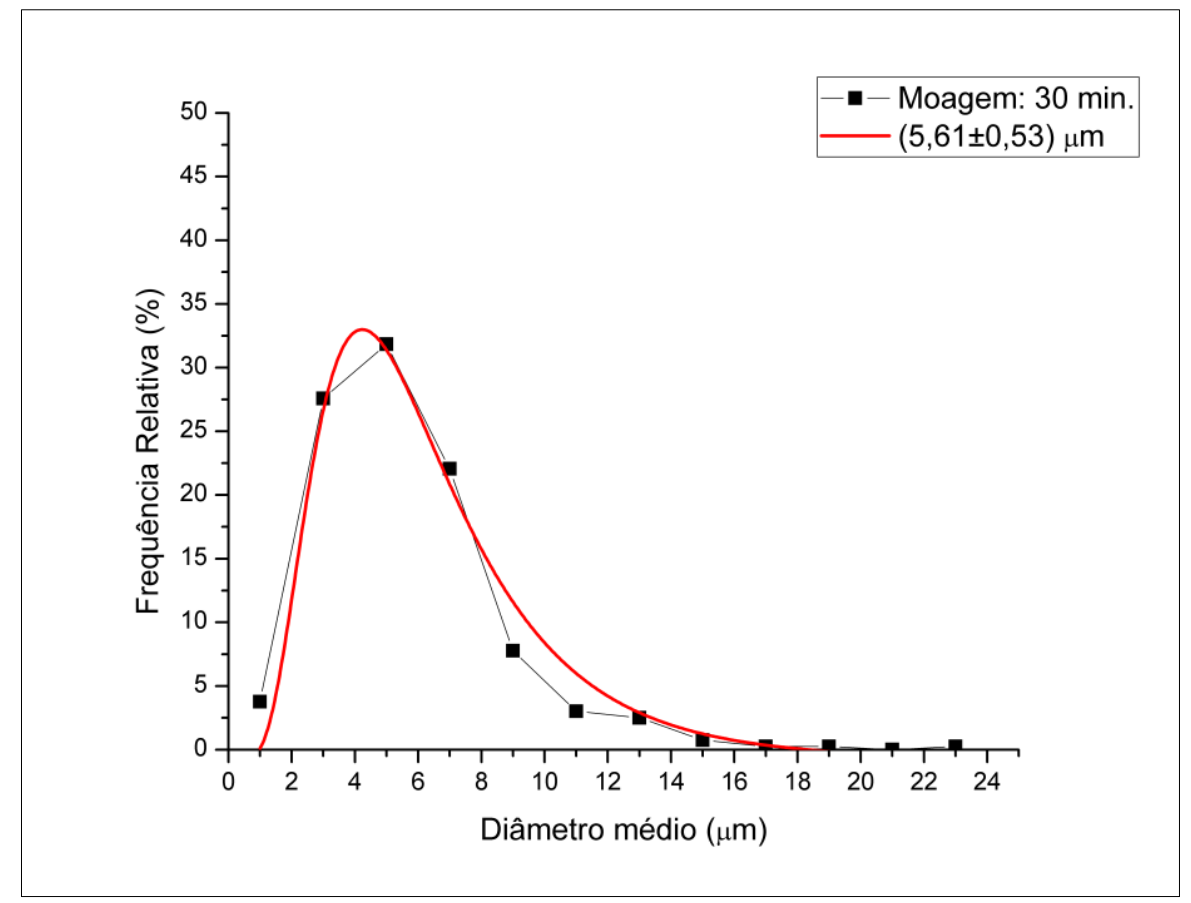


Figura 27: Distribuição dos tamanhos de grãos do ímã produzido com 45 minutos de moagem (45-A).

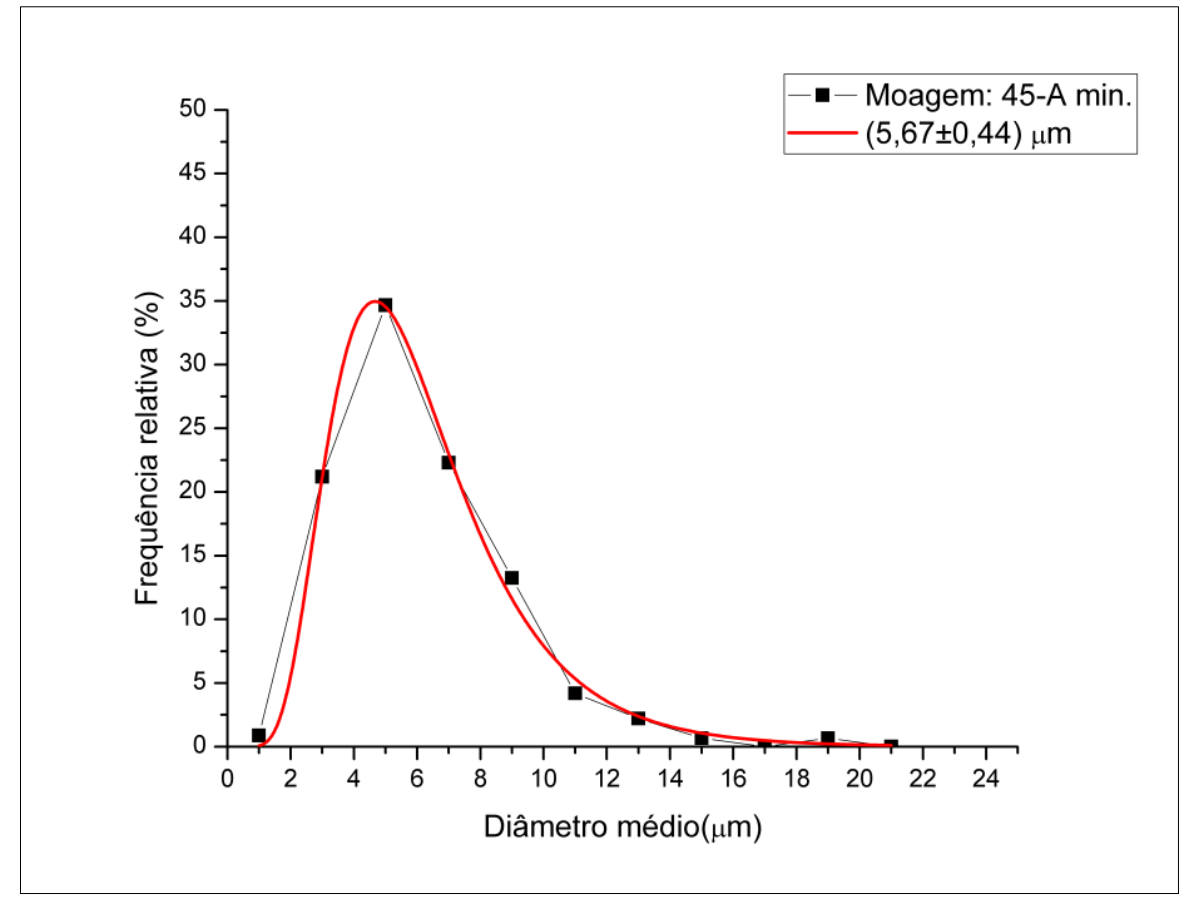

Figura 28:Distribuição dos tamanhos de grãos do ímã produzido com 45 minutos de moagem (45-B).

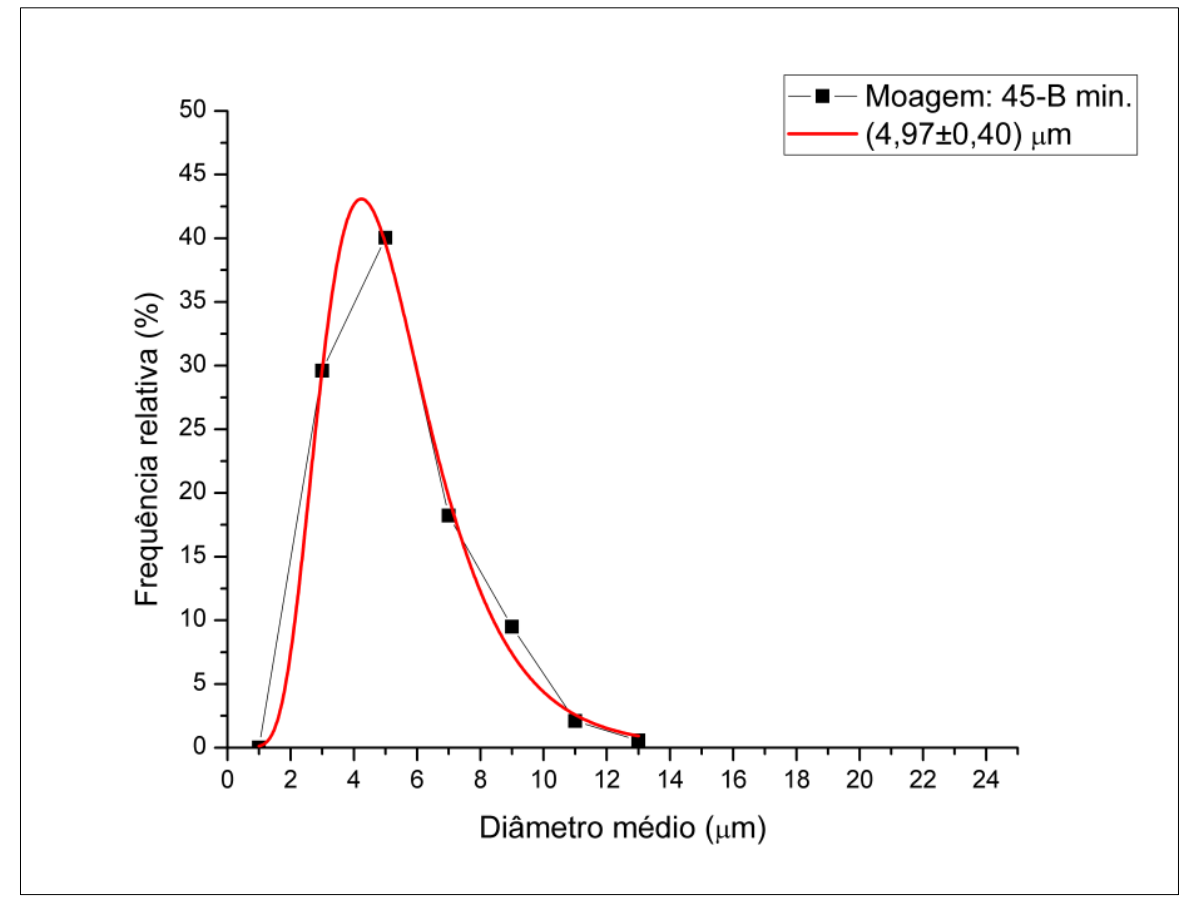


Figura 29: Distribuição dos tamanhos de grãos do ímã produzido com 60 minutos de moagem.

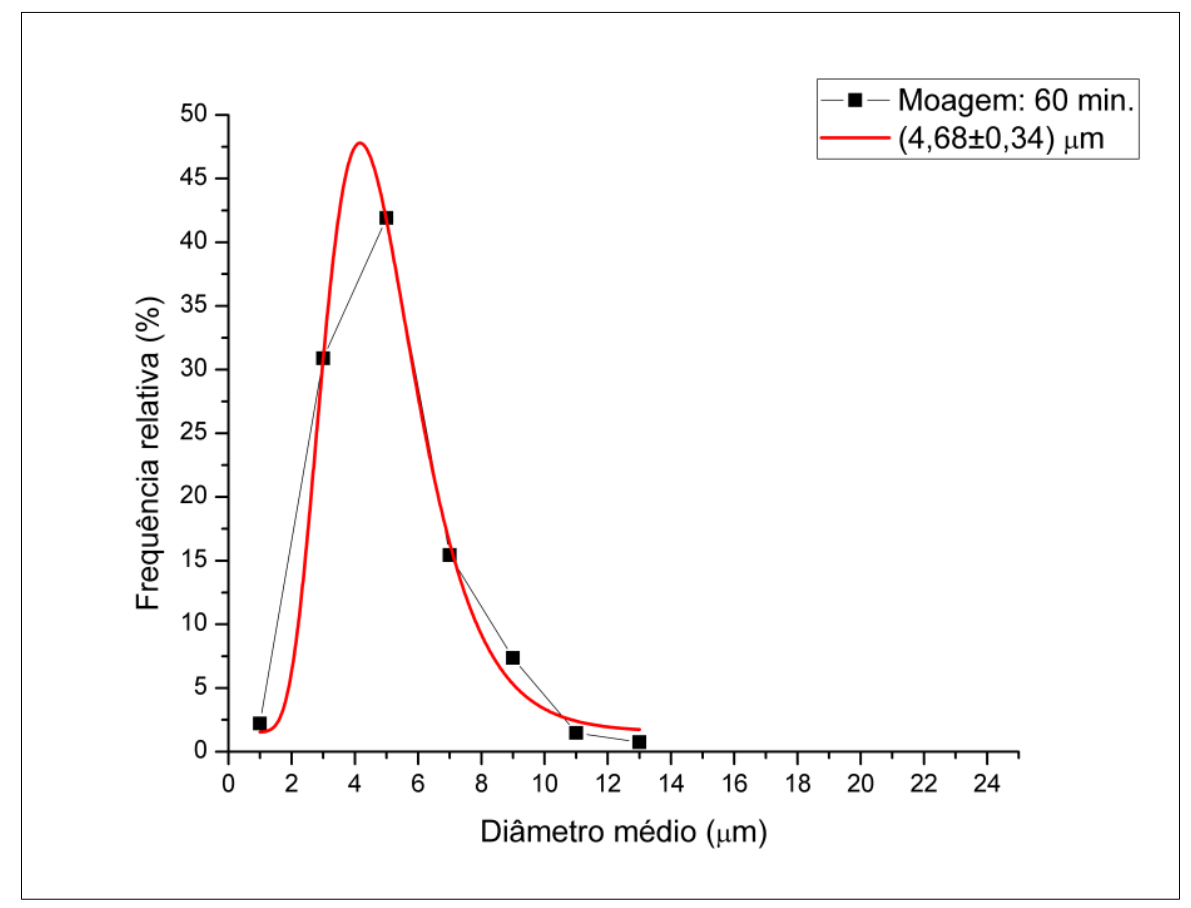

Figura 30: Distribuição dos tamanhos de grãos do ímã produzido com 75 minutos de moagem.

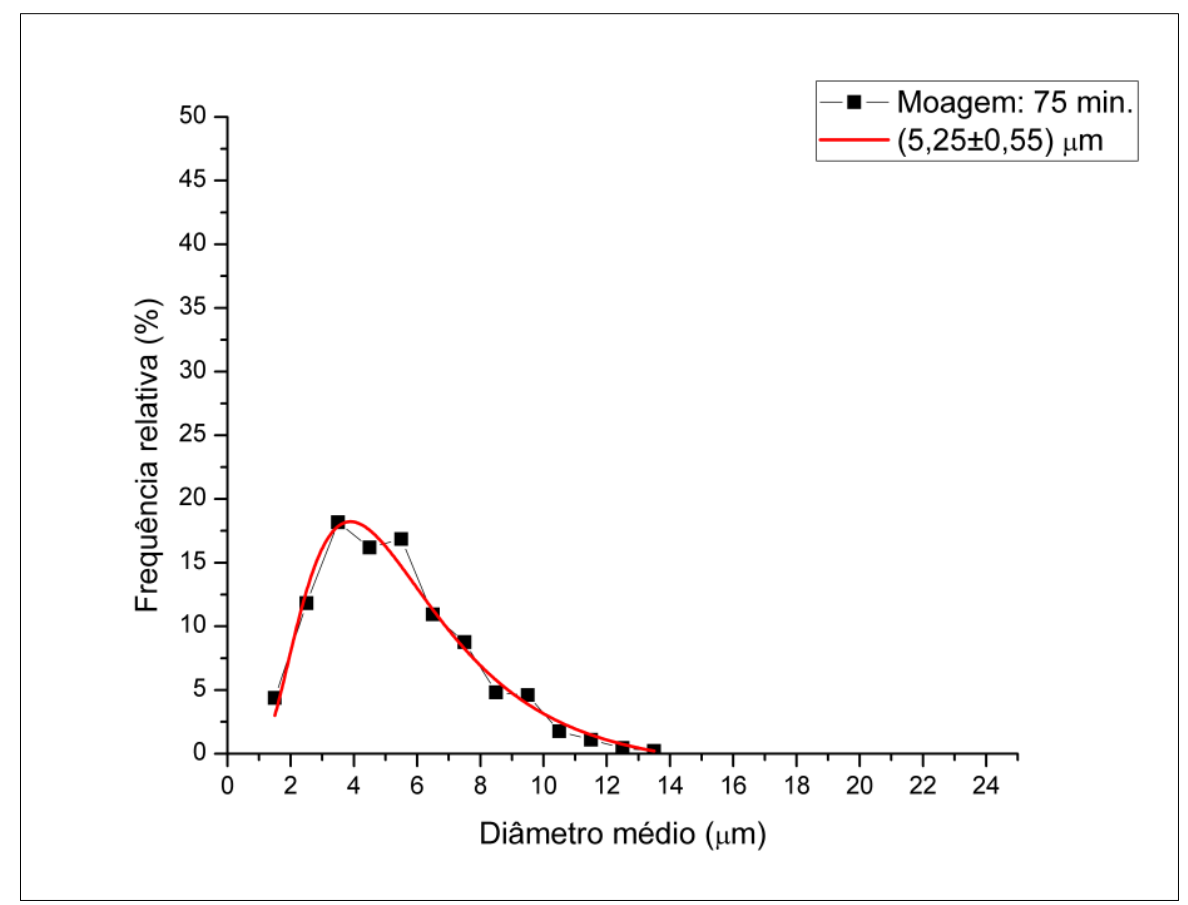


A Tab.6 sumariza os dados obtidos de diâmetro médio e seus respectivos desvios.

Tabela 6: Diâmetro médio dos grãos e seus respectivos desvios.

\begin{tabular}{ccc}
\hline $\begin{array}{c}\text { Tempo de moagem } \\
(\min .)\end{array}$ & Diâmetro médio $(\mu \mathrm{m})$ & Desvio padrão $( \pm \mu \mathrm{m})$ \\
\hline 30 & 5,61 & 0,53 \\
$45-A$ & 5,67 & 0,44 \\
$45-B$ & 4,97 & 0,40 \\
60 & 4,68 & 0,34 \\
75 & 5,25 & 0,54 \\
\hline
\end{tabular}

As amostras analisadas apresentaram diâmetros médios de grão aproximados, sendo o menor igual a 4,68 $\mu \mathrm{m}$ e o maior igual a 5,67 $\mu \mathrm{m}$. Apesar disso, as distribuições são diferentes. Os menores desvios foram encontrados nas amostras processadas entre 45 e 60 minutos de moagem, indicando uma maior homogeneidade da microestrutura para estas condições. Já as amostras processadas por 30 e 75 minutos de moagem apresentaram desvios superiores, indicando que tais condições não são ideais para o processamento.

O tamanho médio de grãos ideal para ímãs permanentes compreende uma faixa entre 2 e $6 \mu \mathrm{m}$ [46-48], e todas as amostras apresentam diâmetros médios nesta faixa, porém a distribuição é heterogênea, como é possível avaliar com base nos desvios.

A condição ideal seria que a distribuição apresentasse os menores valores de desvios (maior homogeneidade), gerando um ganho de propriedades magnéticas [49].

A heterogeneidade da distribuição dos diâmetros médios de grão caracteriza-se como um defeito microestrutural que tem efeitos negativos às propriedades magnéticas, já que propriedades magnéticas tais como a coercividade intrínseca está intimamente ligada à microestrutura [49].

Distribuições muito heterogêneas favorecem a formação de domínios reversos, reduzindo a coercividade intrínseca, efeito evidente nas amostras que apresentaram distribuições mais heterogêneas (30 e 75 minutos de moagem). 
Como foi brevemente discutido no tópico 5.1, os ímãs produzidos com 30 minutos de moagem apresentaram uma distribuição de diâmetros de grãos ampla, sendo que a literatura diz que tais grãos grandes são originários de partículas grandes, cujas quais não foram diminuídas durante a moagem. Ou seja, neste caso, o tempo de moagem foi insuficiente para promover uma redução do tamanho de partícula de modo efetivo [37].

Já nos ímãs produzidos com 75 minutos de moagem, também se observa a presença de grãos grandes. A presença destes grãos grandes sugere que o mecanismo de crescimento anormal de grãos ocorreu para esta condição. Este mecanismo ocorre quando um pó de granulometria muito baixa é sinterizado à temperaturas altas (neste caso, sinterizado à $1100^{\circ} \mathrm{C}$ ). Este pó apresenta uma área superficial muito grande, favorecendo termodinamicamente o crescimento anormal de alguns grãos em relação a outros [37].

Deve-se ressaltar que, o processo de crescimento anormal de grãos não pode ser identificado através da distribuição de diâmetros de grão. Esta hipótese é abordada neste trabalho com base em trabalhos de referência que sugerem que tal mecanismo ocorre devido às condições de processamento [37, 38, 40, 48].

Os ímãs produzidos à partir de tempos intermediários de moagem (com $45 \mathrm{e}$ 60 minutos, respectivamente) apresentaram uma homogeneidade maior de suas microestruturas em relação às anteriores, evidenciando a existência de uma condição ótima de processamento deste material para as condições descritas no presente trabalho.

\subsection{Textura Cristalográfica}

A quantificação da textura cristalográfica pela técnica de difração de raios-X tem sido amplamente utilizada nos ímãs permanentes de terras-raras de forma satisfatória, pois apresenta concordância com a técnica de figuras de polo. $\mathrm{O}$ uso da técnica de difração de raios-X tem grandes vantagens em relação à técnica de figuras de polo, pois além de não ser necessário nenhum arranjo especial, a coleta de resultados é mais rápida para quantificar o grau de alinhamento [50].

A textura cristalográfica dos ímãs produzidos foi calculada segundo o método descrito no item 4.3.4. As Figs.31-35 apresentam os padrões de difração dos ímãs produzidos. 
Figura 31: Padrão de difração de raios-X do ímã produzido com 30 minutos de moagem.

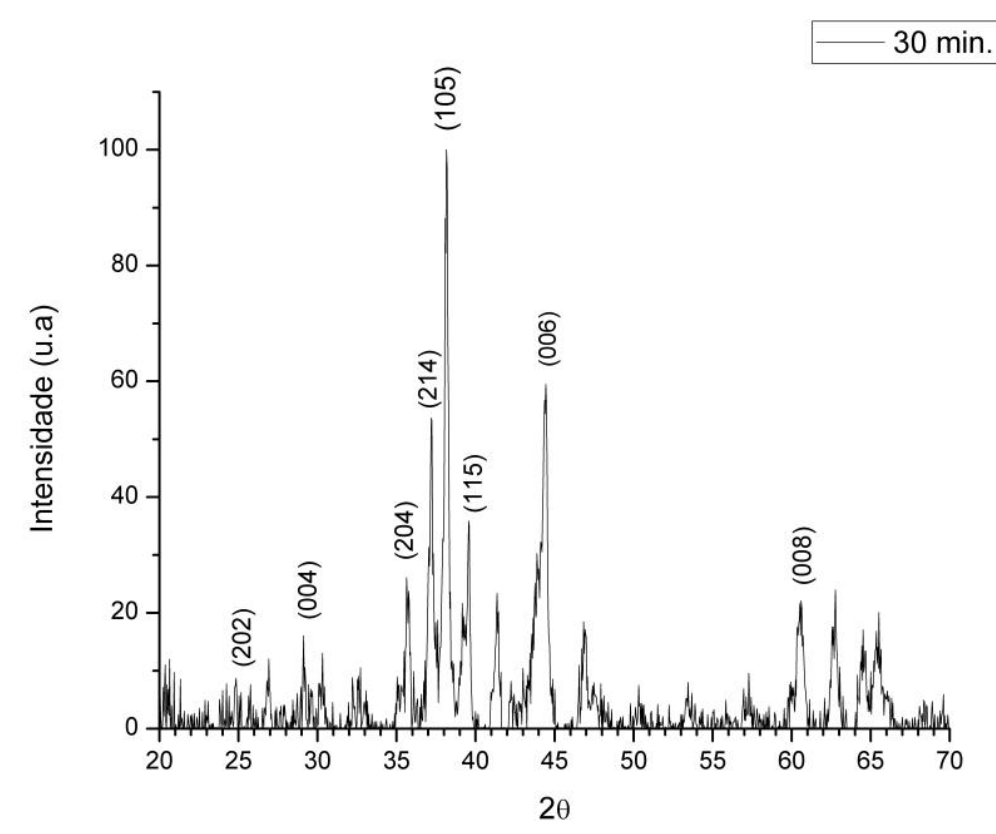

Figura 32: Padrão de difração de raios-X do ímã produzido com 45 minutos de moagem $(45-A)$.

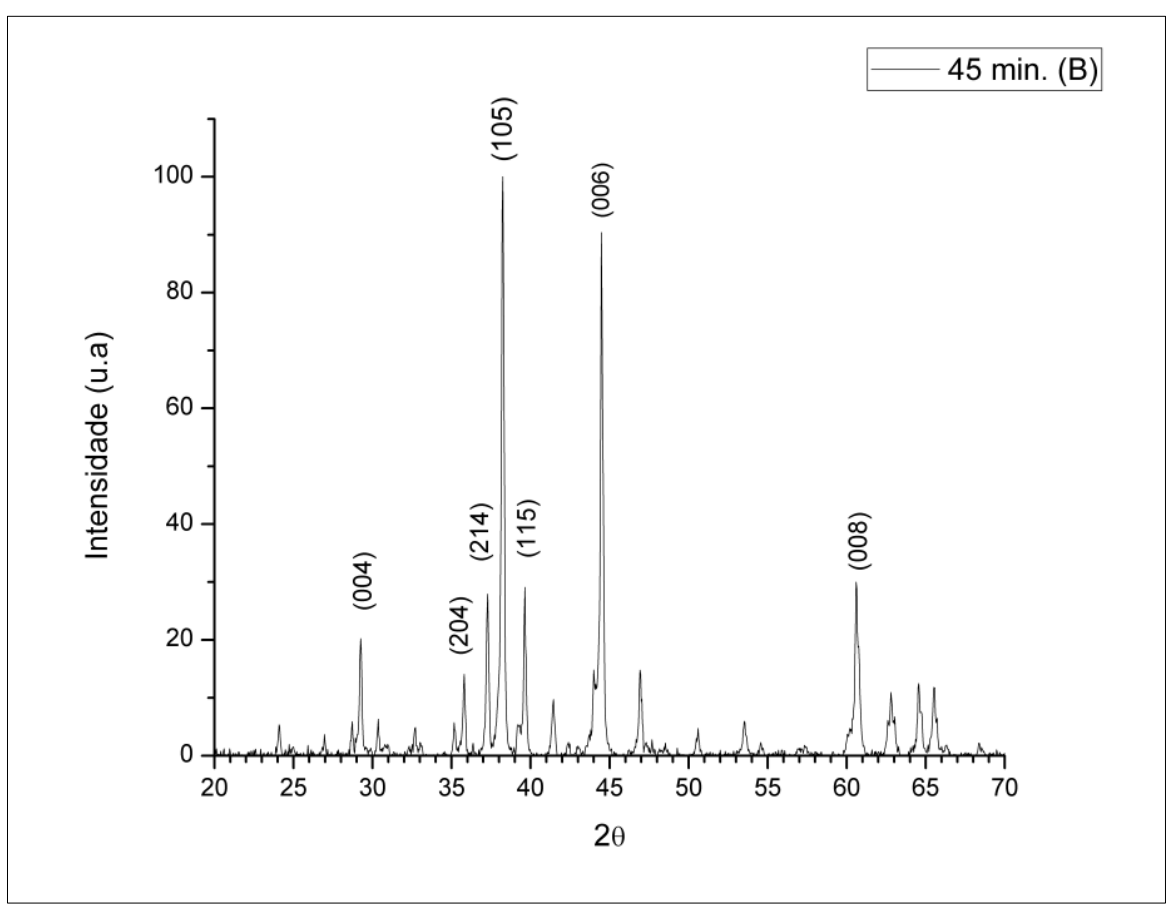


Figura 33: Padrão de difração de raios-X do ímã produzido com 45 minutos de moagem (45-B).

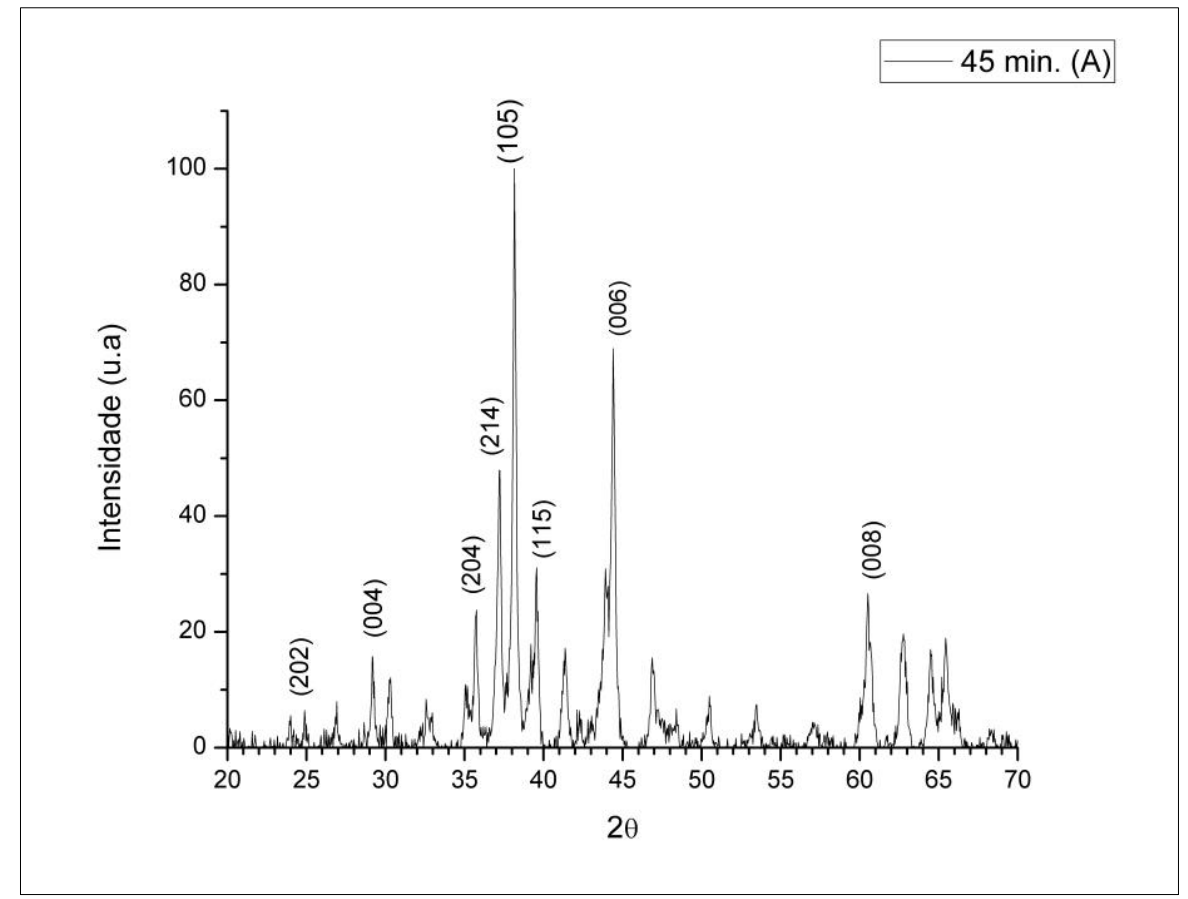

Figura 34: Padrão de difração de raios- $X$ do ímã produzido com 60 minutos de moagem.

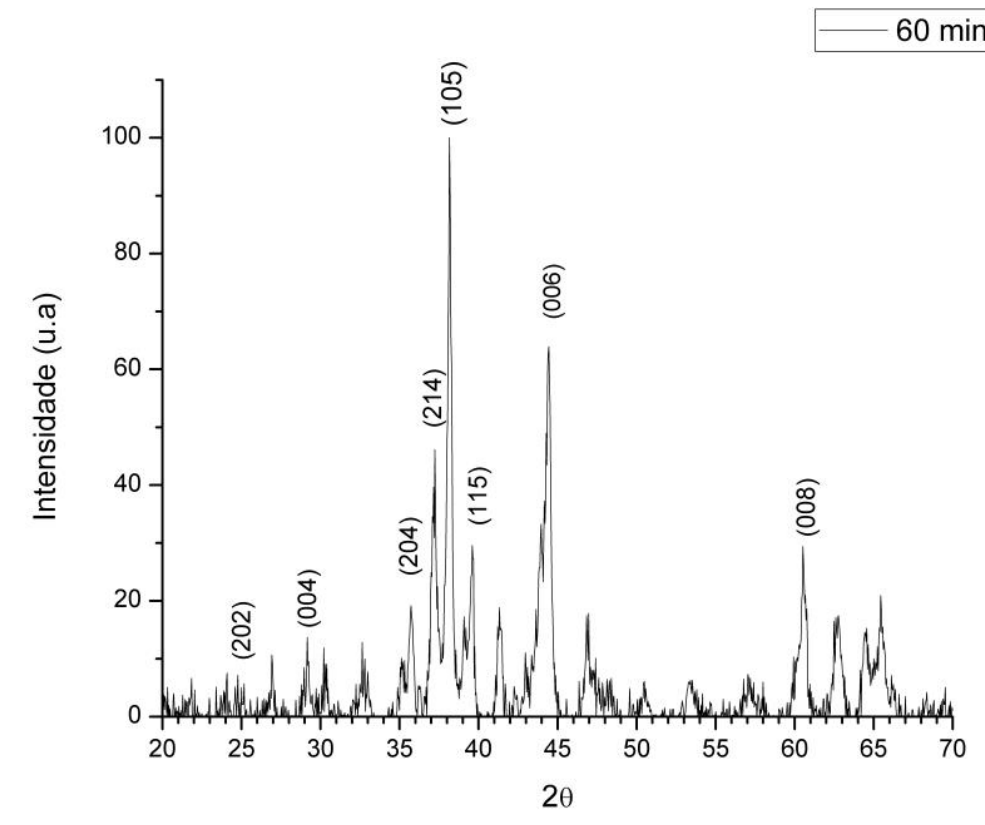


Figura 35: Padrão de difração de raios-X do ímã produzido com 75 minutos de moagem.

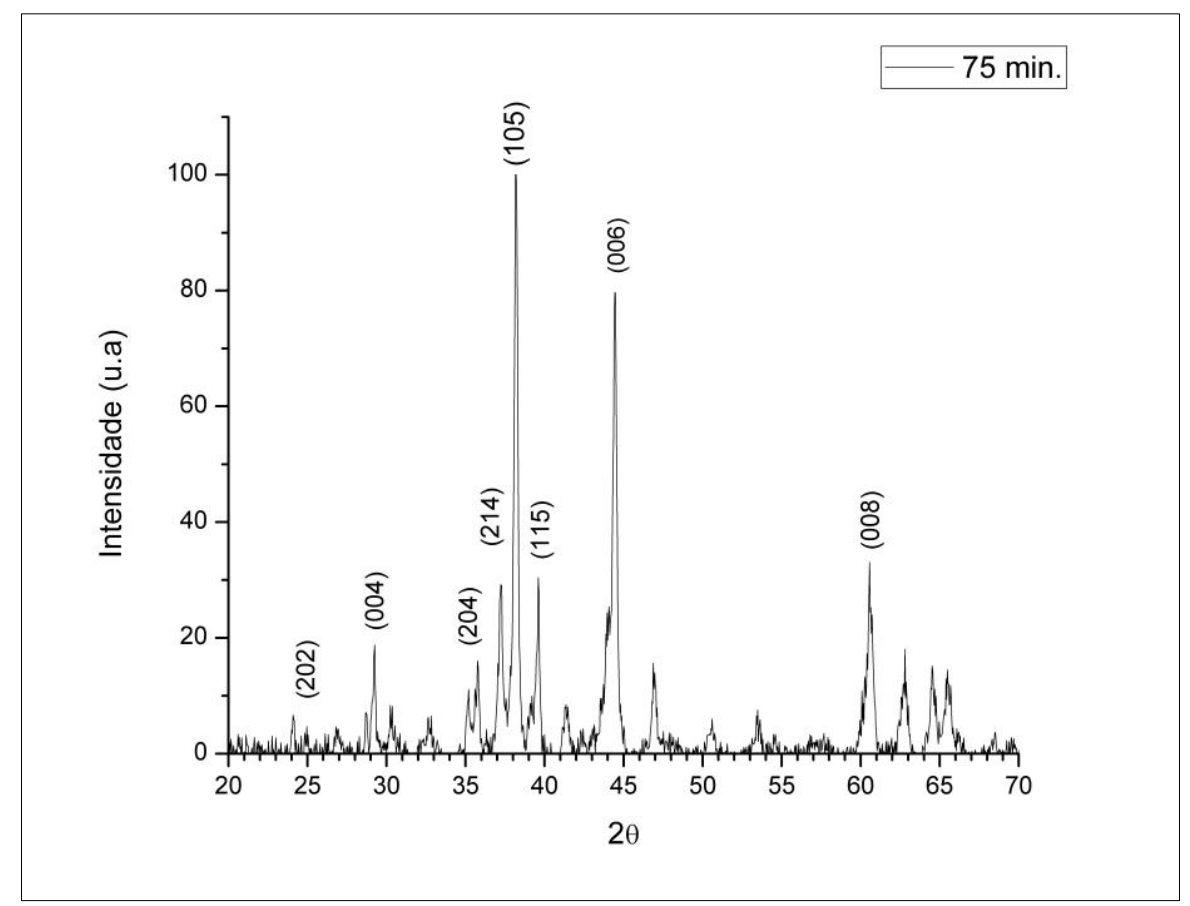

Os planos cristalográficos das amostras foram identificados utilizando a ficha JCPDS - ICDD no 79-1994 (referentes à fase $\mathrm{Nd}_{2} \mathrm{Fe}_{14} \mathrm{~B}$ em um ímã isotrópico).

A partir das intensidades dos planos, o grau de alinhamento foi calculado e sumarizado na Tab.7.

Tabela 7: Cálculo do grau de alinhamento dos ímãs produzidos.

\begin{tabular}{cc}
\hline Tempo de moagem (min.) & $<\cos \theta>$ \\
\hline 30 & 0,90 \\
$45-\mathrm{A}$ & 0,94 \\
$45-\mathrm{B}$ & 0,96 \\
60 & 0,93 \\
75 & 0,95 \\
\hline
\end{tabular}

Todos os ímãs produzidos apresentaram um grau de alinhamento acima de 0,90, porém o ímã que apresentou o maior grau de alinhamento $(<\cos \theta>=0,96)$ foi a amostra 45-B. 
Analisando os padrões de difração de raios-X, observa-se que 0 ímã produzido com 45 minutos de moagem (45-B) apresenta uma intensidade dos

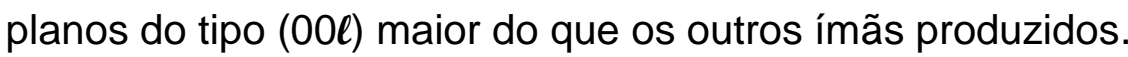

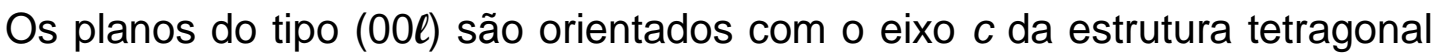
da fase $\mathrm{Nd}_{2} \mathrm{Fe}_{14} \mathrm{~B}$, e é chamado de eixo de fácil magnetização. O plano (105) mesmo não sendo um plano correspondente à direção de fácil magnetização aparece nos padrões de difração dos ímãs permanentes, pois $70 \%$ de sua

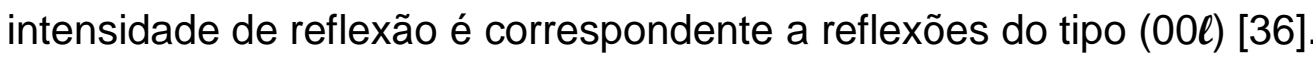

Altos valores de remanência seriam esperados para ímãs com alto grau de alinhamento, uma vez que as duas grandezas são diretamente proporcionais. Porém este comportamento não foi observado. Enquanto que o ímã 45-B apresentou uma remanência de 1,38T com um grau de alinhamento de 0,96, o ímã produzido com 75 minutos de moagem apresentou uma remanência 1,05T com um grau de alinhamento de 0,95.

Seriam esperados altos valores de remanência para todas as amostras produzidas, uma vez que todas apresentam faixas semelhantes de grau de alinhamento.

A remanência pode ser calculada a partir da equação 11:

$$
B_{r}=<\cos \theta>f P \mu_{0} M_{s}
$$

Onde:

P é a densidade relativa dos ímãs produzidos;

$f$ é fração volumétrica de fase $\mathrm{Nd}_{2} \mathrm{Fe}_{14} \mathrm{~B}$, onde muitos trabalhos reportam que esta fração volumétrica varia entre $0,83-0,85$ para a composição $\mathrm{Nd}_{16} \mathrm{Fe}_{76} \mathrm{~B}_{8}$;

$\mu_{0} M_{s}$ é a polarização de saturação da fase $\mathrm{Nd}_{2} \mathrm{Fe}_{14} \mathrm{~B}$, que vale $1,61 \mathrm{~T}$;

Os fatores que poderiam estar influenciando a remanência são a densidade dos ímãs produzidos, o grau de alinhamento e a fração volumétrica. Porém, tanto a densidade de cada ímã produzido como o grau de alinhamento estão na mesma faixa de valores (vide tabelas 3 e 5, respectivamente), o que indicaria que o único parâmetro que poderia estar variando de um ímã para outro seria a fração volumétrica de fase magnética [45]. 
Assumindo que a fração volumétrica de fase magnética apresente valores entre 0,83 e 0,85 como a literatura reporta [51], a remanência de cada ímã foi calculada segundo a equação 11, onde os únicos parâmetros que estão variando são a densidade e o grau de alinhamento. Os resultados estão descritos na Tab.8.

Tabela 8: Valores da remanência $\left(B_{r}\right)$ calculados em função do grau de alinhamento $(<\cos \theta>)$.

\begin{tabular}{|c|c|c|c|c|c|c|}
\hline $\begin{array}{l}\text { Tempo de } \\
\text { moagem } \\
\text { (min.) }\end{array}$ & $\begin{array}{c}\text { Fração } \\
\text { volumétrica } \\
\text { (f) }\end{array}$ & $\begin{array}{c}\mu_{0} M_{s} \\
(T)\end{array}$ & $\begin{array}{c}\text { Densidade } \\
\text { relativa } \\
(\%)\end{array}$ & $<\cos \theta>$ & $\begin{array}{c}B_{r} \\
\text { medido } \\
(T)\end{array}$ & $\begin{array}{c}\mathrm{B}_{\mathrm{r}} \\
\text { calculado } \\
(\mathrm{T})\end{array}$ \\
\hline 30 & $0,83-0,85$ & 1,61 & 95,6 & 0,90 & 1,02 & $1,14-1,17$ \\
\hline $45-A$ & $0,83-0,85$ & 1,61 & 97,3 & 0,94 & 1,06 & $1,21-1,24$ \\
\hline 45-B & $0,83-0,85$ & 1,61 & 97,6 & 0,96 & 1,38 & $1,24-1,27$ \\
\hline 60 & $0,83-0,85$ & 1,61 & 97,5 & 0,93 & 1,05 & $1,20-1,23$ \\
\hline 75 & $0,83-0,85$ & 1,61 & 97,3 & 0,95 & 1,05 & $1,23-1,26$ \\
\hline
\end{tabular}

Todas as remanências calculadas a partir das densidades relativas e do grau de alinhamento dos ímãs apresentaram faixas de valores superiores aos valores obtidos, com exceção do ímã 45-B, onde a remanência obtida é maior do que a calculada.

Como as densidades relativas e o grau de alinhamento de todos os ímãs estão concentrados na mesma faixa de valores (com uma variação pequena entre os valores) pode-se afirmar que a influência desses parâmetros sobre os valores calculados de remanência é pequena.

Comparando os valores de remanência calculados e os valores obtidos pode-se dizer que a fração volumétrica de fase magnética (f) dos ímãs produzidos não está na faixa que a literatura reporta.

Para investigar esta hipótese, a fração volumétrica de fase magnética foi calculada em função das propriedades magnéticas obtidas. A Tab.9 apresenta os resultados obtidos. 
Tabela 9: Valores da fração volumétrica de fase magnética calculada a partir das propriedades magnéticas dos ímãs produzidos.

\begin{tabular}{ccccccc}
\hline $\begin{array}{c}\text { Tempo } \\
\text { de } \\
\text { moagem } \\
\text { (min.) }\end{array}$ & $\begin{array}{c}\mathbf{B}_{\mathbf{r}} \text { medido } \\
(\mathbf{T})\end{array}$ & $\begin{array}{c}\text { Densidade } \\
\text { relativa (\%) }\end{array}$ & $<\cos \theta>$ & $\boldsymbol{\mu}_{0} \mathbf{M}_{\mathbf{s}}(\mathbf{T})$ & $\begin{array}{c}\text { Fração } \\
\text { volumétrica } \\
\text { teórica (f) }\end{array}$ & $\begin{array}{c}\text { Fração } \\
\text { volumétrica } \\
\text { calculada } \\
(\mathbf{f})\end{array}$ \\
\hline $\mathbf{3 0}$ & 1,02 & 95,6 & 0,90 & 1,61 & $0,83-0,85$ & 0,74 \\
$\mathbf{4 5 - A}$ & 1,06 & 97,3 & 0,94 & 1,61 & $0,83-0,85$ & 0,72 \\
$\mathbf{4 5 - B}$ & 1,38 & 97,6 & 0,96 & 1,61 & $0,83-0,85$ & 0,92 \\
$\mathbf{6 0}$ & 1,05 & 97,5 & 0,93 & 1,61 & $0,83-0,85$ & 0,72 \\
$\mathbf{7 5}$ & 1,05 & 97,3 & 0,95 & 1,61 & $0,83-0,85$ & 0,71 \\
\hline
\end{tabular}

Como se pode observar, as frações volumétricas de fase magnética referente aos ímãs que apresentaram menores remanências são menores do que a faixa teórica $(0,83-0,85)$. Esta redução na fração volumétrica calculada pode ser um indicativo de oxidação da fase $\mathrm{Nd}_{2} \mathrm{Fe}_{14} \mathrm{~B}$ [45].

Já amostra que apresentou a maior remanência (45-B), calculou-se uma fração volumétrica superior à faixa teórica, o que pode indicar uma ausência de degradação da fase $\mathrm{Nd}_{2} \mathrm{Fe}_{14} \mathrm{~B}$ [45]. 


\section{CONCLUSÕES}

Os ímãs sinterizados produzidos a partir de tempos de moagem de alta energia iguais à 45 minutos apresentaram as maiores propriedades magnéticas entre os ímãs produzidos. $O$ ímã produzido com 45 minutos de moagem (45-B) apresentou a maior remanência $\left(\mathrm{B}_{\mathrm{r}}=1,38 \mathrm{~T}\right)$, maior coercividade indutiva $\left({ }_{b} \mathrm{H}_{\mathrm{c}}=\right.$ $836 \mathrm{KA} / \mathrm{m})$, maior produto de energia máximo $\left(\mathrm{BH}_{\text {máx }}=330 \mathrm{KJ} / \mathrm{m}^{3}\right)$ e maior fator de quadratura (SF $=0,95)$. Já o ímã produzido com 60 minutos de moagem apresentou a maior coercividade intrínseca $\left(\mathrm{i}_{\mathrm{c}}=907,2 \mathrm{KA} / \mathrm{m}\right)$.

Comparando a melhor condição de processamento (45-B) com a pior condição apresentada (75 minutos de moagem), houve um ganho de $35 \%$ em remanência, 31\% em coercividade intrínseca, $130 \%$ em produto de energia máximo e $41 \%$ em fator de quadratura, evidenciando uma condição otimizada de processamento da liga no que tânge à moagem de alta energia.

Em relação ao diâmetro médio de grãos e sua distribuição, os tempos de 45 e 60 minutos de moagem apresentaram os menores desvios, indicando que neste intervalo houve uma maior homogeneização destes diâmetros. Propriedades magnéticas como coercividade intrínseca, fator de quadratura e grau de alinhamento são intimamente ligados à microestrutura, sendo otimizados com a homogeneizadção da microestrutra.

Em relação ao grau de alinhamento, o ímã produzido com 45 minutos de moagem (45-B) apresentou o maior valor de grau de alinhamento $(<\cos \theta\rangle=$ $0,96)$, o que é compatível com as propriedades magnéticas apresentadas, principalmente a alta remanência $\left(B_{r}=1,38 \mathrm{~T}\right)$.

Os ímãs produzidos com 45 minutos (45-A) e 60 minutos de moagem apresentaram valores de grau de alinhamento semelhantes $(<\cos \theta>=0,94$ e $0,93)$, com propriedades magnéticas semelhantes. Esse comportamento permite afirmar que a microestrutura exerce um papel muito importante nas propriedades magnéticas finais de um ímã.

Com relação ao cálculo teórico da remanência $(\mathrm{Br})$, os ímãs produzidos apresentaram remanência abaixo da faixa estimada para o valor de grau de alinhamento e fração volumétrica de fase magnética. O cálculo teórico da fração volumétrica de fase magnética a partir das propriedades magnéticas apresentadas pelos ímãs indica que a quantidade de fase magnética é menor 
para os ímãs produzidos do que a faixa calculada na literatura. Já em relação ao ímã 45-B, a fração volumétrica de fase magnética calculada foi próxima a faixa descrita na literatura, indicando que neste caso, a fração volumétrica foi conservada durante o processamento. A diferença nos valores de fração volumétrica é um indicativo de que durante o processamento houve uma degradação mais acentuada da fase magnética para todos os ímãs produzidos, não observada para o ímã 45-B. 


\section{SUGESTÕES PARA TRABALHOS FUTUROS}

Sugere-se como temas para trabalhos futuros:

- Estudar a influência e quantificar o teor de oxigênio nos ímãs sinterizados de NdFeB;

- Caracterizar os pós produzidos por Moagem de Alta Energia (MAE) a fim de estudar a evolução microestrutural após o processo de produção dos ímãs sinterizados; 


\section{REFERÊNCIAS BIBLIOGRÁFICAS}

[1] CULLITY, B.D. Introduction to Magnetic Materials, Massachussetts, Addison-Wesley, 1972.

[2] COEY, J.M.D. Magnetism and Magnetic Materials, Nova York, Cambridge University Press, 2010.

[3] MARTINS, Roberto de Andrade. $O$ estudo experimental sobre o magnetismo na Idade Média, com uma tradução da carta sobre o magneto de Petrus Peregrini, Rev. Bras. Ensino Fís., São Paulo, v.39, n.1, e1601, 2017.

[4] SMITH, J.A. Precursors to Peregrinus: The early history of magnetism and the mariner's compass in Europe. Journal of Medieval History, v.18, p.21-74, 1992.

[5] COEY, J.M.D. The History of Magnetism,

[6] McCURRIE, R.A. Ferromagnetic Materials: Structure and Properties, San Diego, Academic Press Inc., 1994

[7] COEY, J.M.D. Rare-Earth Iron Permanent Magnets, Oxford, Clarendon Press, 1996.

[8] HARRIS, I.R. Rare-earth magnets: properties, processing and applications. In: KILNER, J.A.; SKINNER, S.J.; IRVINE, S.J.C.; EDWARDS, P.P. Materials For Sustainable Energy Applications, Woodhead Publishing Limited, 2012.

[9] VONCKEN, J.H.L. The Rare-Earth Elements: An Introduction. SpringerBriefs in Earth Sciences, 2016.

[10] GOLEV, A.; SCOTT, M.; ERSKINE, P.D.; ALI, S.H.; BALLANTYNE, G.R. Rare Earths Supply Chain: Current Status, Constraints and Opportunities, Resources Policy n.41, 2014, p.52-59.

[11] NAKAMURA,H. The current and future status of rare earth permanent magnets, Scripta Materialia, 2017.

[12] JESS SHANKLEMAN, The Electric Car Revolution Is Accelerating, Bloomberg, 06 jul. $2017 . \quad$ Disponível em: https://www.bloomberg.com/news/articles/2017-07-06/the-electric-car-revolutionis-accelerating. 
[13] PATRICK McGEE, Volvo to use electric motors in all cars from 2019, Financial Times, 05 jul 2017. Disponível em: https://www.ft.com/content/471cd6e2-60bc-11e7-91a7-502f7ee26895.

[14] PAUL HOCKENOS, Power to EV: Norway spearheads Europe's electric vehicle surge, Yale Environment 360, The Guardian, 07 fev. 2017. Disponível em: https://www.theguardian.com/environment/2017/feb/07/power-to-the-ev-norwayspearheads-europes-electric-vehicle-surge.

[15] International Energy Agency Greenhouse Gas R\&D Programme (IEAGHG) - Electric Cars Lead the Transport Charge, Information Paper, 2017. Disponível em:

http://www.ieaghg.org/docs/General Docs/Publications/Information Papers/2017IP42.pdf.

[16] Global Wind Energy Council (GWEC), Relatório Anual sobre a Energia Eólica Mundial, 2016. Disponível em: http://gwec.net/publications/global-windreport-2/global-wind-report-2016/.

[17] LUCAS,J et al., Rare Earths: Science, Technology, Production and Use, Elsevier, 2015.

[18] JILES,D.; Introduction to Magnetism and Magnetic Materials, Londres, Chapman and Hall, 1991.

[19] CULLITY,B.D.; Introduction to Magnetic Materials, Nova Jersey, John Wiley \& Sons Inc., 2009.

[20] CHIKAZUMI,S.; Physics of Ferromagnetism, Grã-Bretanha, Oxford University Press, 2009.

[21] CALLISTER, W.D.; RETSHWISCH, D.G.; Materials Science and Engineering: An Introduction, Oitava Edição, John Wiley \& Sons Inc., 2009;

[22] FARIA,R.N.; LIMA, L.F.C.P.; Introdução ao Magnetismo dos Materiais, São Paulo, Livraria da Física, 2005.

[23] KIANVASH, A.; HARRIS, I.R.; Hydrogen decrepitation as a method of powder preparation of a 2:17-type, $\mathrm{Sm}(\mathrm{Co}, \mathrm{Cu}, \mathrm{Fe}, \mathrm{Zr})_{8,92}$ magnetic alloy, Journal of Materials Science, v.20 (2), p.682-688, 1985. 
[24] HARRIS, I.R.; NOBLE, C.; BAILEY, T. The hydrogen decrepitation of an $\mathrm{Nd}_{15} \mathrm{Fe}_{77} \mathrm{~B}_{8}$ magnetic alloy, Journal of the Less Common Metals, v.106, L1-L4, 1985.

[25] POURARIAN, F.; HUANG, M.Q.; WALLACE, W.E. Influence of hydrogen on the magnetic characteristics of $R_{2} \mathrm{Fe}_{14} \mathrm{~B}(\mathrm{R}=\mathrm{Ce}, \mathrm{Pr}, \mathrm{Nd}, \mathrm{Sm}$ or $\mathrm{Y})$ systems. Journal of the Less Common Metals, v.120, p. 63-70, 1986.

[26] HARRIS, I,R.; McGUINESS, P.J. Hydrogen: its use in the processing of $\mathrm{NdFeB}$-type magnets and characterization of NdFeB-type alloys and magnets. In: $11^{\text {th }}$ international Workshop on Rare-Earth Magnets and Their Applications, Pittsburgh, 1990, p.29-47.

[27] ISNARD, O.; YELON, W.B.; MIRAGLIA, S.; FRUCHART, D. Neutrondiffraction study of the insertion scheme of hydrogen in $\mathrm{Nd}_{2} \mathrm{Fe}_{14} \mathrm{~B}$. Journal of Applied Physics, v.78 (3), p. 1892-1898, 1995.

[28] NOTHNAGEL, P.; MÜLLER, K.-H.; ECKERT, D.; HANDSTEIN, A. The influence of particle size on the coercivity of sintered NdFeB magnets. J. Magn.Magn.Mater. v.101, p.379-381, 1991.

[29] MADAAH HOSSEINI, H.R.; KIANVASH, A. The role of milling atmosphere on microstructure and magnetic properties of a $\mathrm{Nd}_{12,8} \mathrm{Fe}_{79,8} \mathrm{~B}_{7,4}$-type sintered magnet. J.Magn.Magn.Mater, v.281, p.92-96, 2004.

[30] FARIA, R.N et al. A study of Pr-Fe-B magnets Produced by a Low-Cost Powder Method and the Hydrogen Decrepitation Process, Materials Research, v.8, n.2, p.143-145, 2005.

[31] KIANVASH, A.; HARRIS, I.R. The production of a $\mathrm{Nd}_{16} \mathrm{Fe}_{76} \mathrm{~B}_{8}$ sintered magnet by the hydrogen decrepitation/hydrogen vibration milling route, Journal of Alloys and Compounds, v.282, p.213-219, 1999.

[32] JING, X. et al. Influence of Solidification Rate on Microstructures of Cast Strips and Corresponding Sintered NdFeB Magnets, Journal of Rare Earths, v.24, p.306, 2006.

[33] TAKIISHI, H.; LIMA, L.F.C.P.; FARIA, R.N. The Production of Rare-Earth Sintered Magnets by a Low-Cost Powder Technique, Powder Technology, v.127, p.223-225, 2002. 
[34] RAMESH, R.; THOMAS, G.; MA, B.M. Magnetization reversal in nucleation controlled magnets. II. Effect of grain size and size distribution on intrinsic coercivity of Fe-Nd-B magnets. J.Appl.Phys. v.64, n.11, p.6416-6423, 1988.

[35] HERBST, J.F.; TRACY, J.C. On estimating remanent magnetization from $x$ ray pole figure data, J.Appl.Phys., v.50 (6), p.4283-4284, 1979.

[36] CASTRO, A.R.M. Textura Cristalográfica e Avaliação de Domínios Magnéticos em Ímãs de PrFeB. Tese de Doutorado, Instituto de Pesquisas Energéticas e Nucleares, 2001.

[37] PÉRIGO, E.A.; SOARES, E.P.; LEAL NETO, R.M.; MOTTA, C.C.; FARIA, R.N. A Study of High-Energy Milling for the Production of Sintered PrFeB Magnets, Mater.res., v.10, n.3, p.311-314, 2007.

[38] BITTNER, F. et al., Normal and Abnormal Grain Growth in Fine-Grained $\mathrm{Nd}-\mathrm{Fe}-\mathrm{B}$ Sintered Magnets Prepared from $\mathrm{He}$ Jet Milled Powders, J.Magn.Magn.Mater.,2016.

[39] LI, W.F.; OHKUBO, T.; HONO, K.; SAGAWA, M. The Origin of Coercivity Decrease in Fine Grained Nd-Fe-B Sintered Magnets, J.Magn.Magn,Mater., v.321, p. 1100-1105, 2009.

[40] SZYMURA, S.; RABINOVICH, Y.; BALA, H.; SERGEEV, V.; POTAPOVA, L. Effect of grain size distribution on the properties of sintered (Nd,Dy)-(Fe, Co)-B magnets. Journal de Physique III, EDP Sciences, v.2 (2), p.267-273, 1992.

[41] PÉRIGO, E.A. Estudo das Correlações entre Microestrutura, Propriedades Magnéticas e Fator de Quadratura em Ímãs Sinterizados de PrFeB e NdFeB Processados com Hidrogênio, Tese de Doutorado, Instituto de Pesquisas Energéticas e Nucleares, 2009.

[42] MISHRA, R.K.; CHEN, J.K.; THOMAS, G.J. Appl.Phys., v.59. p.2244, 1986.

[43] MAKITA, K.; YAMASHITA, O. Appl.Phys.Lett., v.74, p.2056, 1999.

[44] WOODCOCK, T.G.; GUTFLEISCH, O. Acta Mater., v.59, p.1026, 2011.

[45] FARIA, R.N. et al. Relation between grain alignment and magnetic properties of Pr-Fe-B sintered magnets, J.Magn.Magn.Mater, v.238, p.38-46, 2002. 
[46] GUTFLEISCH, O. Controlling the properties of high energy density permanent magnetic materials by different processing routes, J.Phys.D: Appl.Phys, v.33, R157-R172, 2000.

[47] FIDLER, J. et al, Recent developments in hard magnetic bulk materials, J.Phys.: Condens. Matter, v.16, S455-S470, 2004.

[48] RODEWALD, W.; WALL, B.; FERNENGEL, W. Grain Growth Kinetics in Sintered Nd-Fe-B Magnets, IEEE Trans.Magn, v.33, p.3841- 3843, 1997.

[49] HONO, K.; SEPEHRI-AMIN, H. Strategy for high-coercivity Nd-Fe-B magnets, Scripta Materialia. v.67, p.530-535, 2012.

[50] PÉRIGO, E.A.; TAKIISHI, H.; MOTTA, C.C.; FARIA, R.N.; LIMA, N.B. Determination of the crystallographic texture of sintered PrFeB magnets based on $X$-ray diffraction patterns, J.Magn.Magn.Mater, v.320, e40-e42, 2008.

[51] DURST, K.D.; KRONMÜLLER, H. J.Magn.Magn.Mater, v.59, p.86, 1986. 